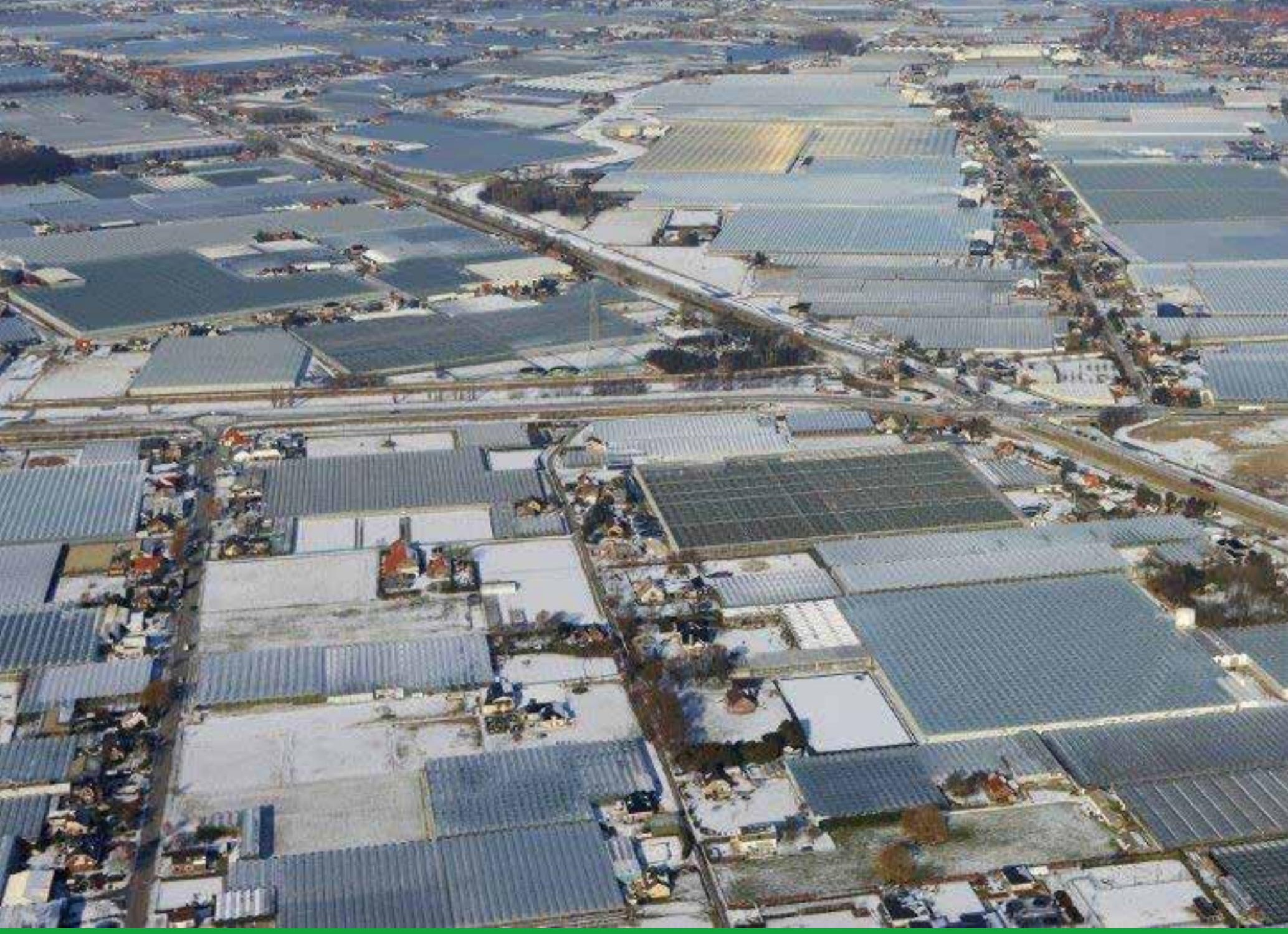

\title{
Energiemonitor van de Nederlandse glastuinbouw 2018
}





\section{Energiemonitor van de Nederlandse glastuinbouw 2018}

Nico van der Velden en Pepijn Smit

Dit onderzoek is uitgevoerd door Wageningen Economic Research in opdracht van en gefinancierd door het ministerie van Landbouw, Natuur en Voedselkwaliteit en de stichting Programmafonds

Glastuinbouw/Glastuinbouw Nederland.

Wageningen Economic Research

Wageningen, november 2019

RAPPORT

2019-111

ISBN 978-94-6395-204-0 
Van der Velden, Nico en Smit, Pepijn, 2019. Energiemonitor van de Nederlandse glastuinbouw 2018. Wageningen, Wageningen Economic Research, Rapport 2019-111. 62 blz.; 27 fig.; 5 tab.; 20 ref.

Tussen glastuinbouwsector en overheid is een doel voor de totale $\mathrm{CO}_{2}$-emissie in 2020 van 4,6 Mton overeengekomen. In 2018 is de $\mathrm{CO}_{2}$-emissie gelijk gebleven op het niveau van 5,7 Mton; de glastuinbouw zat hiermee boven het doel. Over de gehele periode 2014-2018 is de $\mathrm{CO}_{2}$-emissie ook stabiel. In deze periode daalde de $\mathrm{CO}_{2}$-emissie door krimp van het areaal, meer duurzame energie en meer inkoop elektriciteit maar steeg door meer verkoop elektriciteit vanuit wkk en toename van het energiegebruik per $\mathrm{m}^{2}$. Het aandeel duurzame energie in het totaal energiegebruik groeide in 2018 naar 7,3\%. Aardwarmte was de belangrijkste duurzame bron en de groei zat bij aardwarmte en inkoop duurzame warmte. Ook de energie-efficiëntie bleef in 2018 gelijk. Het aandeel van aardgas in de energievoorziening daalde in de periode $2010-2018$ van $88 \%$ naar $81 \%$.

The greenhouse horticulture sector and the Dutch government have agreed on a target of 4.6 Mtonnes of total $\mathrm{CO}_{2}$ emissions in 2020. In 2018, $\mathrm{CO}_{2}$ emissions from the sector remained at the same level as the previous year (5.7 Mtonnes), which exceeded the target level. $\mathrm{CO}_{2}$ emissions were also stable over the entire 2014-2018 period. Although $\mathrm{CO}_{2}$ emissions were reduced during this period due to a smaller production area, more use of sustainable energy and more purchasing of electricity, they also rose due to more sale of electricity from CHP and increased energy consumption per $\mathrm{m}^{2}$. In 2018 , the proportion of sustainable energy in total energy consumption increased to $7.3 \%$. Geothermal heat was the most important sustainable source, with the largest growths in geothermal heat and purchase of sustainable heat. Energy efficiency also remained the same in 2018. Between 2010 and 2018, the share of natural gas in the total energy supply for the sector has decreased from $88 \%$ to $81 \%$.

Trefwoorden: energie, $\mathrm{CO}_{2}$-emissie, energie-efficiëntie, duurzame energie, warmtekrachtkoppeling, inkoop warmte, glastuinbouw, intensivering, extensivering, energiebesparing

Dit rapport is gratis te downloaden op https://doi.org/10.18174/505786 of op www.wur.nl/economicresearch (onder Wageningen Economic Research publicaties).

(C) 2019 Wageningen Economic Research

Postbus 29703, 2502 LS Den Haag, T 07033583 30, E communications.ssg@wur.nl, www.wur.nl/economic-research. Wageningen Economic Research is onderdeel van Wageningen University \& Research.

\section{(cc) BY-NC}

Dit werk valt onder een Creative Commons Naamsvermelding-Niet Commercieel 4.0 Internationaallicentie.

(C) Wageningen Economic Research, onderdeel van Stichting Wageningen Research, 2019 De gebruiker mag het werk kopiëren, verspreiden en doorgeven en afgeleide werken maken. Materiaal van derden waarvan in het werk gebruik is gemaakt en waarop intellectuele eigendomsrechten berusten, mogen niet zonder voorafgaande toestemming van derden gebruikt worden. De gebruiker dient bij het werk de door de maker of de licentiegever aangegeven naam te vermelden, maar niet zodanig dat de indruk gewekt wordt dat zij daarmee instemmen met het werk van de gebruiker of het gebruik van het werk. De gebruiker mag het werk niet voor commerciële doeleinden gebruiken.

Wageningen Economic Research aanvaardt geen aansprakelijkheid voor eventuele schade voortvloeiend uit het gebruik van de resultaten van dit onderzoek of de toepassing van de adviezen.

Wageningen Economic Research is ISO 9001:2015 gecertificeerd.

Wageningen Economic Research Rapport 2019-111 | Projectcode 2282200493

Foto omslag: Shutterstock 


\section{Inhoud}

Woord vooraf $\quad 5$

$\begin{array}{ll}\text { Samenvatting } & 6\end{array}$

S.1 $\mathrm{CO}_{2}$-emissie glastuinbouw sinds 2014 stabiel $\quad 6$

$\begin{array}{lll}\text { S.2 Overige uitkomsten } & 7\end{array}$

$\begin{array}{ll}\text { S.3 Methode } & 9\end{array}$

$\begin{array}{ll}\text { Summary } & 10\end{array}$

S.1 $\mathrm{CO}_{2}$ emissions from greenhouse horticulture have been stable since $2014 \quad 10$

S.2 Other outcomes 11

$\begin{array}{ll}\text { S.3 Method } & 13\end{array}$

1

Inleiding

$1.1 \quad$ Beleidsmatige context 14

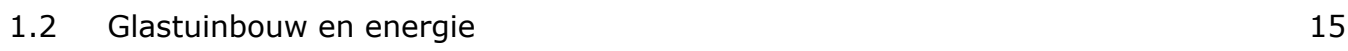

$\begin{array}{lll}1.3 & \text { De Energiemonitor } & 16\end{array}$

2

$\begin{array}{ll}\text { Ontwikkeling indicatoren } & 18\end{array}$

2.1 Inleiding $\quad 18$

$\begin{array}{lll}2.2 \mathrm{CO}_{2} \text {-emissie } & 18\end{array}$

$\begin{array}{lll}2.3 & \text { Energie-efficiëntie } & 19\end{array}$

$\begin{array}{lll}2.4 & \text { Aandeel duurzame energie } & 21\end{array}$

2.5 Kwantitatieve analyse ontwikkeling $\mathrm{CO}_{2}$-emissie $\quad 22$

2.6 Energiekosten $\quad 24$

$\begin{array}{lll}2.7 & \text { Warmte- en elektriciteitsgebruik } & 25\end{array}$

2.8 Energievoorziening zonder $\mathrm{CO}_{2}$-emissie $\quad 26$

$3 \quad$ Nadere analyse duurzame energie $\quad 28$

$\begin{array}{lll}3.1 & \text { Inleiding } & 28\end{array}$

$\begin{array}{lll}3.2 & \text { Bronnen van duurzame energie } & 28\end{array}$

3.2.1 Toepassing 28

3.2.2 Ontwikkeling per bron 30

3.2.3 Productie, inkoop, verkoop en consumptie $\quad 32$

3.2.4 Bedrijfsstructuur 33

$\begin{array}{lll}3.3 & \text { Reductie } \mathrm{CO}_{2} \text {-emissie } & 35\end{array}$

$\begin{array}{lll}3.4 & \text { Warmtedekking } & 37\end{array}$

$\begin{array}{lll}3.5 & \text { Inkoop } \mathrm{CO}_{2} & 38\end{array}$

$\begin{array}{lll}4.1 & \text { Inleiding } & 40\end{array}$

$\begin{array}{lll}4.2 & \text { Wkk glastuinbouwbedrijven } & 40\end{array}$

$\begin{array}{lll}4.3 & \text { Inkoop van warmte } & 42\end{array}$

4.4 Reductie $\mathrm{CO}_{2}$-emissie $\quad 42$

$4.5 \quad$ Elektriciteitsbalans $\quad 44$

$\begin{array}{lll}4.6 & \text { Warmtegebruik en warmtedekking } & 46\end{array}$

$\begin{array}{llr}5 & \text { Reflectie } & 47\end{array}$

$\begin{array}{lrr}6 & \mathbf{5 0}\end{array}$ 
Bijlage 1 Definities, methode en bronnen

Bijlage 2 Kenmerken en energie-indicatoren glastuinbouw

Bijlage 3 Energiegebruik glastuinbouw (totale glastuinbouwareaal en niet gecorrigeerd voor temperatuur) a)

58

Bijlage 4 Gebruik en reductie $\mathrm{CO}_{2}$-emissie per duurzame energiebron en inkoop $\mathrm{CO}_{2}$

59

Bijlage 5 Gebruik en reductie $\mathrm{CO}_{2}$-emissie wkk en inkoop van warmte 60 


\section{Woord vooraf}

Het energiegebruik van de glastuinbouw is sterk in beweging. Enerzijds door anticipatie op de marktvraag naar glastuinbouwproducten, anderzijds door de energietransitie. In 2014 maakten de glastuinbouwsector en de rijksoverheid de Meerjarenafspraak Energietransitie Glastuinbouw 20142020. Hierin staat de $\mathrm{CO}_{2}$-emissie centraal. Voor 2020 is een maximale $\mathrm{CO}_{2}$-emissie van 4,6 Mton overeengekomen. In het programma Kas als Energiebron (KaE) werken de glastuinbouw en de overheid gezamenlijk aan het realiseren van het $\mathrm{CO}_{2}$-doel.

Om realistische keuzes te kunnen maken in beleid en belangenbehartiging is het belangrijk de werkelijke ontwikkelingen en achtergronden in beeld te hebben. De Energiemonitor van de Nederlandse Glastuinbouw kwantificeert en analyseert jaarlijks de ontwikkeling van het energiegebruik en bijbehorende energie-indicatoren. $\mathrm{Na}$ een substantiële daling in de periode $2010-2014$ is de $\mathrm{CO}_{2}$ emissie in de periode 2014-2018 stabiel. Voor de toekomst heeft Glastuinbouw Nederland de ambitie om al in 2040 geen $\mathrm{CO}_{2}$ meer uit te stoten. In het Klimaatakkoord is voor de glastuinbouw een ambitie opgenomen van een maximale uitstoot van 2,2 Mton in 2030 op basis van de benodigde afspraken in het Klimaatakkoord.

Informatie en inzichten uit de Energiemonitor worden ook gebruikt voor ander onderzoek. Zo heeft Wageningen Economic Research een prognose gemaakt van de $\mathrm{CO}_{2}$-emissie van de glastuinbouw in 2030. Voor toekomstige reductie van de $\mathrm{CO}_{2}$-emissie zijn inspanningen van zowel bedrijfsleven als overheid nodig op de terreinen energiebesparing en energievoorziening en zijn energie-infrastructuur en de $\mathrm{CO}_{2}$-voorziening van de glastuinbouw de achilleshiel. Voortbouwend op de prognose van de $\mathrm{CO}_{2}-$ emissie is ook een prognose gemaakt van de $\mathrm{CO}_{2}$-behoefte van de glastuinbouw.

Reductie van de $\mathrm{CO}_{2}$-emissie brengt met zich mee dat er naast energiebesparing minder aardgas en meer duurzame energie wordt gebruikt en meer elektriciteit en warmte wordt ingekocht. Hierbij spelen regionale aspecten zoals infrastructuur en lokale samenwerking een belangrijke rol. Voortbouwend op de Energiemonitor is een methodiek ontwikkeld om op regionaal niveau te monitoren en is voor Greenport West-Holland een nulmeting uitgevoerd. Voortbouwend op de nationale prognose 2030 zijn ook prognoses gemaakt voor het Westland en het Oostland.

Wageningen Economic Research maakt jaarlijks de Energiemonitor Glastuinbouw in opdracht van de Stichting Kennis in je Kas van de glastuinbouwsector en het ministerie van Landbouw, Natuur en Voedselkwaliteit (LNV). De begeleidingscommissie bestond uit Piet Broekharst (Glastuinbouw Nederland), Paulina Chromik (LNV) en Krijn Poppe (Wageningen Economic Research). Vele partijen hebben informatie aangeleverd. Aan het onderzoek is gewerkt door Nico van der Velden (projectleider), Pepijn Smit en Ruud van der Meer.

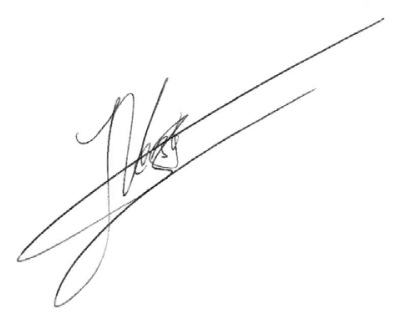

Prof.dr.ir. J.G.A.J. (Jack) van der Vorst Algemeen Directeur Social Sciences Group (SSG) Wageningen University \& Research 


\section{Samenvatting}

\section{S.1 $\mathrm{CO}_{2}$-emissie glastuinbouw sinds 2014 stabiel}

De totale $\mathrm{CO}_{2}$-emissie van de glastuinbouw is in 2018 gelijk gebleven op het niveau van 5,7 Mton en ligt daarmee 1,1 Mton boven het doel voor 2020, dat in 2017 werd aangescherpt naar 4,6 Mton. Over de periode $2014-2018$ is de $\mathrm{CO}_{2}$-emissie stabiel.

Het $\mathrm{CO}_{2}$-emissiedoel heeft betrekking op de totale $\mathrm{CO}_{2}$-emissie en wordt bepaald met de IPCC-methode (Intergovernmental Panel on Climate Change) en is hiermee verbonden aan het fossiele brandstofverbruik van de glastuinbouw op locatie. In- en verkoop van elektriciteit en warmte tellen niet mee.

Voor een beter begrip en betere duiding wordt ook de invloed van de buitentemperatuur en de $\mathrm{CO}_{2}$ emissie van de teelt bepaald. $\mathrm{Bij}$ de $\mathrm{CO}_{2}$-emissie van de teelt wordt de emissie die samenhangt met de verkoop van elektriciteit uit aardgasgestookte wkk verrekend. De $\mathrm{CO}_{2}$-emissie na temperatuurcorrectie en de $\mathrm{CO}_{2}$-emissie van de teelt zijn over de periode 2014-2018 ook vrijwel onveranderd.

De totale $\mathrm{CO}_{2}$-emissie lag in $20181,1 \mathrm{Mton}$ (16\%) en de $\mathrm{CO}_{2}$-emissie van de teelt 39\% onder het niveau van 1990. Voor Nederland als geheel was de $\mathrm{CO}_{2}$-emissie in $20181 \%$ lager dan in 1990. De glastuinbouw doet het bij het terugdringen van de $\mathrm{CO}_{2}$-emissie daarmee beter dan de landelijke ontwikkeling (zie paragraaf 2.2).

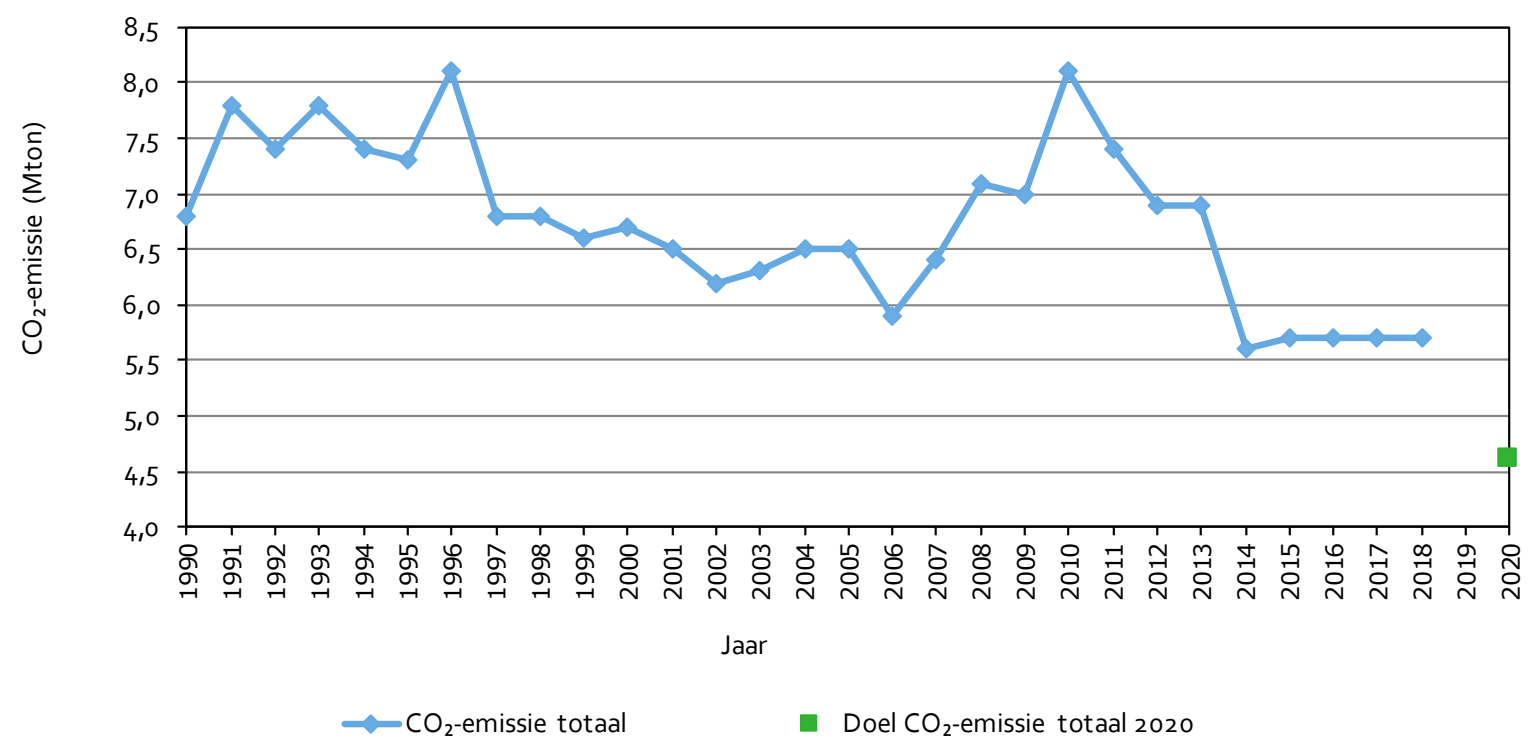

Figuur S.1 $\mathrm{CO}_{2}$-emissie totaal a)

a) Cijfers 2018 voorlopig.

De totale $\mathrm{CO}_{2}$-emissie na temperatuurcorrectie bleef in de periode 2014-2018 vrijwel gelijk (-0,1 Mton) terwijl in de periode 2010-2014 een reductie van 1,9 Mton werd gerealiseerd. In de meest recente periode leidden een groeiend energiegebruik per $\mathrm{m}^{2}$ ( $+0,35$ Mton) en meer verkoop van elektriciteit $(+0,10 \mathrm{Mton})$ tot een toename van de $\mathrm{CO}_{2}$-emissie. Dit werd gecompenseerd door krimp van het areaal (-0,24 Mton), toename van het gebruik van duurzame energie (-0,20 Mton) en toename van de inkoop elektriciteit (-0,11 Mton). In de periode 2010-2014 lieten de eerste twee factoren een tegenovergestelde ontwikkeling zien met als gevolg dat de $\mathrm{CO}_{2}$-emissie in die periode substantieel daalde. 
Door groei van het energiegebruik per $\mathrm{m}^{2}$ in de periode 2014-2018 nam de $\mathrm{CO}_{2}$-emissie toe. Dit laat zien dat het effect van intensivering groter was dan het totaaleffect van extensivering en energiebesparing. De intensivering is het gevolg van de toenemende marktvraag naar energieintensievere glastuinbouwproducten met een hogere waarde die in de winterperiode worden geteeld met groeilicht. In de periode 2010-2014 was het totaaleffect van extensivering en energiebesparing groter dan het effect van intensivering (zie paragraaf 2.5 ).

Om het doel voor 2020 te realiseren, dient de $\mathrm{CO}_{2}$-emissie met nog 1,1 Mton te worden gereduceerd. Op basis van de ontwikkelingen in de achterliggende jaren en de actuele inzichten voor de nabije toekomst wordt verwacht dat de $\mathrm{CO}_{2}$-emissie tot en met 2020 niet veel zal veranderen en de doelstelling voor 2020 waarschijnlijk niet zal worden gehaald (zie hoofdstuk 5).

\section{S.2 Overige uitkomsten}

Duurzame energie groeit

Het aandeel duurzame energie groeide in 2018 met 0,9 procentpunt naar 7,3\% en de absolute hoeveelheid duurzame energie groeide met 0,7 PJ naar 7,4 PJ. In 2018 steeg zowel het aandeel als het absolute gebruik minder hard dan in 2017. Het aandeel duurzame energie is in de jaren 2017 en 2018 vrijwel gelijk aan het aandeel in Nederland als geheel (zie paragraaf 2.4).

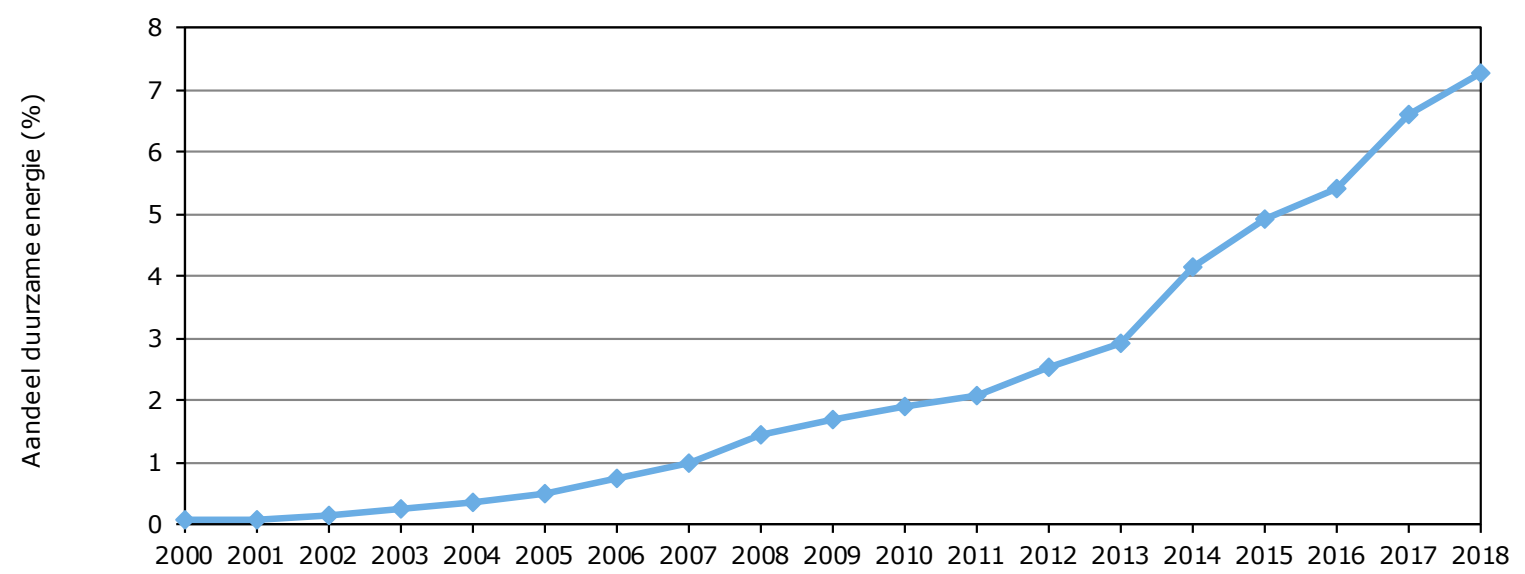

Jaar

Figuur S.2 Aandeel duurzame energie a)

a) Cijfers 2018 voorlopig.

In 2018 voorzag aardwarmte in $48 \%$ van de toegepaste duurzame energie, op afstand gevolgd door inkoop duurzame elektriciteit (20\%), zonne-energie (11\%), biobrandstoffen $(10 \%)$ en de inkoop van duurzame warmte $(10 \%)$. De inkoop van duurzaam gas $(<1 \%)$ bleef ook in 2018 beperkt. De groei zat bij aardwarmte en inkoop duurzame warmte, de inkoop van duurzame elektriciteit nam af.

Het gebruik van duurzame energie bestond voor $80 \%$ uit warmte en $20 \%$ uit elektriciteit. Duurzame warmte werd voor $87 \%$ zelf geproduceerd en duurzame elektriciteit voor $96 \%$ ingekocht. Het areaal met duurzame energie (exclusief inkoop uit openbare netten) nam in 2018 toe naar bijna 1.500 ha. Dit is $17 \%$ van het totaal areaal. Duurzame energie wordt vooral toegepast op de grotere bedrijven. Zonder gebruik van duurzame energie zou de $\mathrm{CO}_{2}$-emissie van de glastuinbouw in 2018 0,32 Mton hoger zijn geweest

Energievoorziening zonder $\mathrm{CO}_{2}$-emissie en inkoop $\mathrm{CO}_{2}$ groeit

Het aandeel van aardgas in de energievoorziening daalde in de periode $2010-2018$ van $88 \%$ naar $81 \%$. De energievoorziening van de glastuinbouw bleef daarmee nog grotendeels afhankelijk van 
aardgas, maar de eerste stappen om minder afhankelijk te worden zijn gezet (zie paragraaf 2.8). Voor een energievoorziening zonder $\mathrm{CO}_{2}$-emissie is ook externe $\mathrm{CO}_{2}$ nodig voor de gewassen. Het gebruik van externe $\mathrm{CO}_{2}$ is in 2018 met bijna $10 \%$ gegroeid naar 0,64 Mton (zie paragraaf 3.5).

\section{Warmtedekking}

De gemiddelde warmtedekking is bij duurzame warmte $\left(15 \mathrm{~m}^{3}\right.$ a.e. $/ \mathrm{m}^{2}$ ) kleiner dan bij inkoop warmte (23 $\mathrm{m}^{3}$ a.e. $/ \mathrm{m}^{2}$ ) en bij aardgas wkk's $\left(22 \mathrm{~m}^{3}\right.$ a.e. $\left./ \mathrm{m}^{2}\right)$ en vertoont ook een dalende trend. Hierdoor kan het gebruik van duurzame warmte op termijn tegen grenzen aan lopen (zie hoofdstuk 5). Voor reductie van de $\mathrm{CO}_{2}$-emissie op sectorniveau is het van belang dat er hoge dekkingen worden gerealiseerd bij zowel duurzame warmte als bij inkoop warmte. Aandachtspunten hierbij zijn de kosteneffectiviteit bij de SDE, de spreiding van het projectrisico bij de financiering en de projectpartners en de beschikbaarheid van externe $\mathrm{CO}_{2}$. Ook het combineren van meerdere warmtebronnen zonder $\mathrm{CO}_{2}$-emissie op hetzelfde areaal is hierbij een uitdaging.

\section{Ook energie-efficiëntie stabiel}

De energie-efficiëntie ofwel het primair brandstofverbruik per eenheid product bedroeg in $201842 \%$ ten opzichte van 1990 en is sinds 2010 stabiel. Dit komt doordat het primair brandstofverbruik per $\mathrm{m}^{2}$ zich in dezelfde mate ontwikkelde als de fysieke productie per $\mathrm{m}^{2}$. In 2018 namen beiden met ruim $1 \%$ af. In de jaren daarvoor stegen beiden met circa $2 \%$ per jaar. De daling van de fysieke productie in 2018 hangt waarschijnlijk samen met de warme zomer. De daling van het primair brandstofverbruik in 2018 kwam vooral door toename van de elektriciteitsverkoop vanuit aardgas-wkk's (zie

paragraaf 2.3).

Over een langere periode bezien werd de ontwikkeling van de fysieke productie geremd doordat een hogere waarde per eenheid product door kwaliteit en planning van de levering werd nagestreefd (zie paragraaf 2.3).

\section{Energiegebruik en energiekosten}

Het totaal energiegebruik daalde, na groei in de jaren 2014-2017, in 2018 naar 100,5 PJ. Het bestond voor circa $74 \%$ uit warmte en voor circa $26 \%$ uit elektriciteit. In 2010 was dat nog $90 \%$ en $10 \%$. Het energiegebruik per $\mathrm{m}^{2}$ kas nam, na een daling in de periode 2010-2014 (-10\%), in de periode 20142018 toe $(+7 \%)$. Deze groei zat vooral bij de elektriciteitsconsumptie $(+22 \%)$, maar ook bij de warmteconsumptie $(+3 \%)$. De verschuiving naar en de groei van de elektriciteitsconsumptie kwam hoofdzakelijk door de toename van het gebruik van groeilicht. De verkoop van elektriciteit bedroeg in 2018 5,6 miljard kWh. De kosten voor inkoop van energie stegen harder dan de opbrengsten van verkoop waardoor de netto-energiekosten $\left(€ / \mathrm{m}^{2}\right)$ in 2018 toenamen.

\section{Warmtekrachtkoppeling}

Het totaal vermogen van de wkk's ligt sinds 2015 op ruim $2.400 \mathrm{MW}_{\mathrm{e}}$ en is wat kleiner dan in de jaren daarvoor. Dit komt vooral door krimp van het areaal. In 2018 had circa 63\% van het areaal een wkk in gebruik. De gemiddelde gebruiksduur is in 2017 en 2018 toegenomen en lag in 2018 op bijna 3.900 uur, dit is bijna $20 \%$ meer dan in 2016. Dit komt door een verbeterde spark spread (de verhouding tussen de verkoopprijs van elektriciteit en de inkooprijs van aardgas), zowel in 2017 en 2018. De productie bedroeg in 2018 ruim 9 miljard kWh. Dit is 1,2 miljard kWh meer dan in 2016. De wkk's van de glastuinbouw voorzagen in 2018 bijna $8 \%$ van de nationale elektriciteitsconsumptie. Door elektriciteitsproductie met wkk's lag in 2018 de $\mathrm{CO}_{2}$-emissie van de glastuinbouw 2,6 Mton hoger, van elektriciteitscentrales 4,2 Mton lager en per saldo werd op nationaal niveau 1,6 $\mathrm{Mton}^{\mathrm{CO}_{2}-}$ emissie vermeden. Dit komt door de IPCC-methode echter niet tot uiting in de $\mathrm{CO}_{2}$-emissie van de glastuinbouwsector, omdat de $\mathrm{CO}_{2}$-emissie wordt toegeschreven aan de partij waar de uitstoot plaatsvindt en niet aan de gebruiker van energie.

\section{Elektriciteitsvraag en -voorziening}

De elektriciteitsconsumptie van de glastuinbouw groeit sinds 2010 en bedroeg in 2018 naar schatting 6,7 miljard kWh. Dit is 5,5\% van de nationale consumptie. De groei komt vooral door de toename van groeilicht. Na een toename in de periode 2010-2017 met zo'n 20\% stabiliseerde de inkoop van elektriciteit in 2018 op 2,8 miljard kWh. De oorzaken hiervan zijn niet geheel duidelijk. De mate waarin in de elektriciteitsvraag werd voorzien met wkk's daalde van $62 \%$ in 2014 tot $57 \%$ in 2018 . Dit 
hangt samen met de intensivering van groeilicht per $\mathrm{m}^{2}$ in combinatie met de grenzen aan warmtebenutting bij gebruik van warmte uit wkk's.

Inkoop warmte

Door de glastuinbouw ingekochte warmte (exclusief duurzame warmte) nam in 2018 met 0,3 PJ af tot 3,4 PJ. De daling kwam door de grotere fractie duurzaam in de geleverde warmte die meetelt bij duurzame energie. Over de hele periode 2010-2018 nam de inkoop van warmte af van 5,3 naar 3,4 $\mathrm{PJ}$. Het aandeel in het totale energiegebruik bedroeg in 2018 3,4\%. Warmte-inkoop reduceerde de $\mathrm{CO}_{2}$-emissie van de glastuinbouw in 2018 met 0,14 Mton.

\section{S.3 Methode}

In opdracht van de Stichting Kennis in je Kas van de glastuinbouwsector en het ministerie van LNV kwantificeert Wageningen Economic Research jaarlijks de ontwikkeling van de energie-indicatoren $\mathrm{CO}_{2}$-emissie, energie-efficiëntie en aandeel duurzame energie in de glastuinbouw. Hiervoor worden de energiebalans en de fysieke productie in kaart gebracht. Voor de Energiemonitor Glastuinbouw is een methodiek ontwikkeld waarin sectordeskundigen een reeks van informatiebronnen combineren. Om de kwantificering te duiden, worden achtergronden geanalyseerd. De methodiek is vastgelegd in een protocol. 


\section{Summary}

\section{S.1 $\mathrm{CO}_{2}$ emissions from greenhouse horticulture have been stable since 2014}

In 2018, the total $\mathrm{CO}_{2}$ emissions from greenhouse horticulture remained at 5.7 Mtonnes, which exceeded by 1.1 Mtonnes the target for 2020 that was changed in 2017 to 4.6 Mtonnes. $\mathrm{CO}_{2}$ emissions were stable between 2014 and 2018.

The $\mathrm{CO}_{2}$-emission target relates to total $\mathrm{CO}_{2}$ emissions and is determined using the method prescribed by the Intergovernmental Panel on Climate Change (IPCC) and is linked to the fossil fuel consumption of greenhouse operations. Purchases and sales of electricity and heat are not included.

To provide a more complete picture of emissions from the sector, the influence of the outside temperature and the $\mathrm{CO}_{2}$ emissions of crop production have also been determined. The $\mathrm{CO}_{2}$ emissions from crop production exclude the emissions associated with the sale of electricity from Combined Heat and Power generation ( $\mathrm{CHP}$ ) using natural gas as a fuel. The $\mathrm{CO}_{2}$ emissions after temperature correction and the $\mathrm{CO}_{2}$ emissions from crop production also remained essentially unchanged between 2014 and 2018.

Relative to 1990 levels, total $\mathrm{CO}_{2}$ emissions in 2018 were 1.1 Mtonnes ( $16 \%$ ) lower and $\mathrm{CO}_{2}$ emissions from crop production were 39\% lower. For the Netherlands as a whole, the $\mathrm{CO}_{2}$ emissions in 2018 were $1 \%$ lower than they were in 1990 . Greenhouse horticulture is therefore performing better than the national average in reducing $\mathrm{CO}_{2}$ emissions (see Section 2.2).

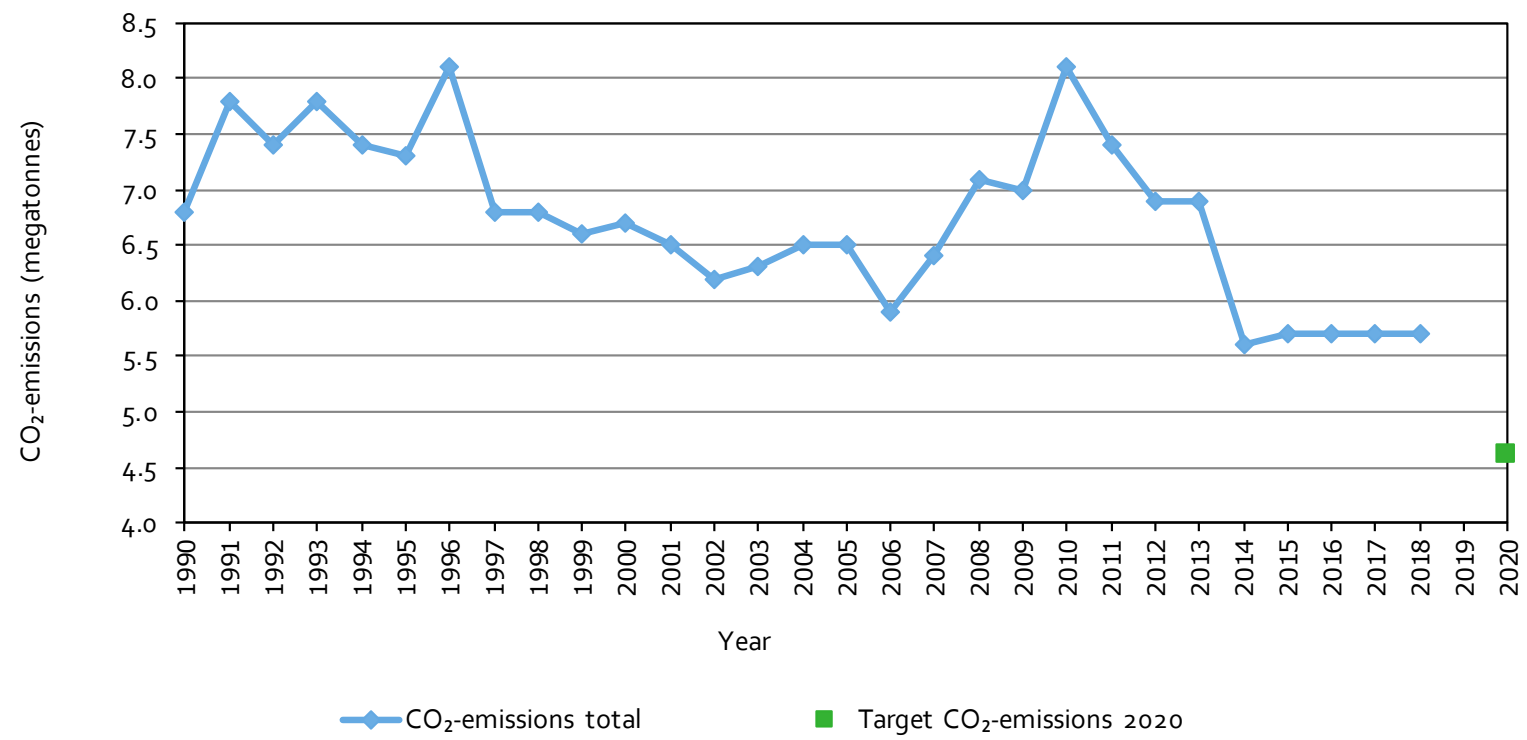

Figure S.1 Total $\mathrm{CO}_{2}$-emissions a)

a) Data for 2018 are provisional.

Between 2014 and 2018, the total $\mathrm{CO}_{2}$ emissions after temperature correction remained essentially level (-0.1 Mtonne), while a reduction of 1.9 Mtonnes was achieved between 2010 and 2014. In the most recent period, increasing energy consumption per $\mathrm{m}^{2}$ of production area $(+0.35$ Mtonne) and more sales of electricity ( +0.10 Mtonne) led to an increase in $\mathrm{CO}_{2}$ emissions. This was compensated by a smaller production area (-0.24 Mtonne), increased use of renewable energy ( -0.20 Mtonne) and 
increased purchases of electricity (-0.11 Mtonne). Between 2010 and 2014, the first two factors showed opposite trends, resulting in a substantial decline in $\mathrm{CO}_{2}$ emissions in that period.

A growth in energy consumption per $\mathrm{m}^{2}$ during the 2014-2018 period meant $\mathrm{CO}_{2}$ emissions increased. This shows that the effect of intensification was greater than the total effect of extensification and energy savings. The intensification is the result of growing market demand for more energy-intensive and higher-value greenhouse products that are cultivated using supplemental lighting during the winter period. In the 2020-2014 period, the total effect of extensification and energy savings was greater than that of intensification (see Section 2.5).

To achieve the target in $2020, \mathrm{CO}_{2}$ emissions in the sector must be reduced by another 1.1 Mtonnes. Based on developments in recent years and current predictions for the near future, it is expected that the $\mathrm{CO}_{2}$ emissions will not change very much until 2020 and that the target for 2020 will probably not be achieved (see Chapter 5).

\section{S.2 Other outcomes}

Proportion of sustainable energy is increasing

In 2018 , the proportion of sustainable energy increased by 0.9 percentage point to $7.3 \%$, and the absolute amount of sustainable energy increased by $0.7 \mathrm{PJ}$ to $7.4 \mathrm{PJ}$. In that year, both the proportion and absolute use increased less rapidly than in 2017. The proportion of sustainable energy in 2017 and 2018 was essentially equal to the proportion in the Netherlands as a whole (see Section 2.4).

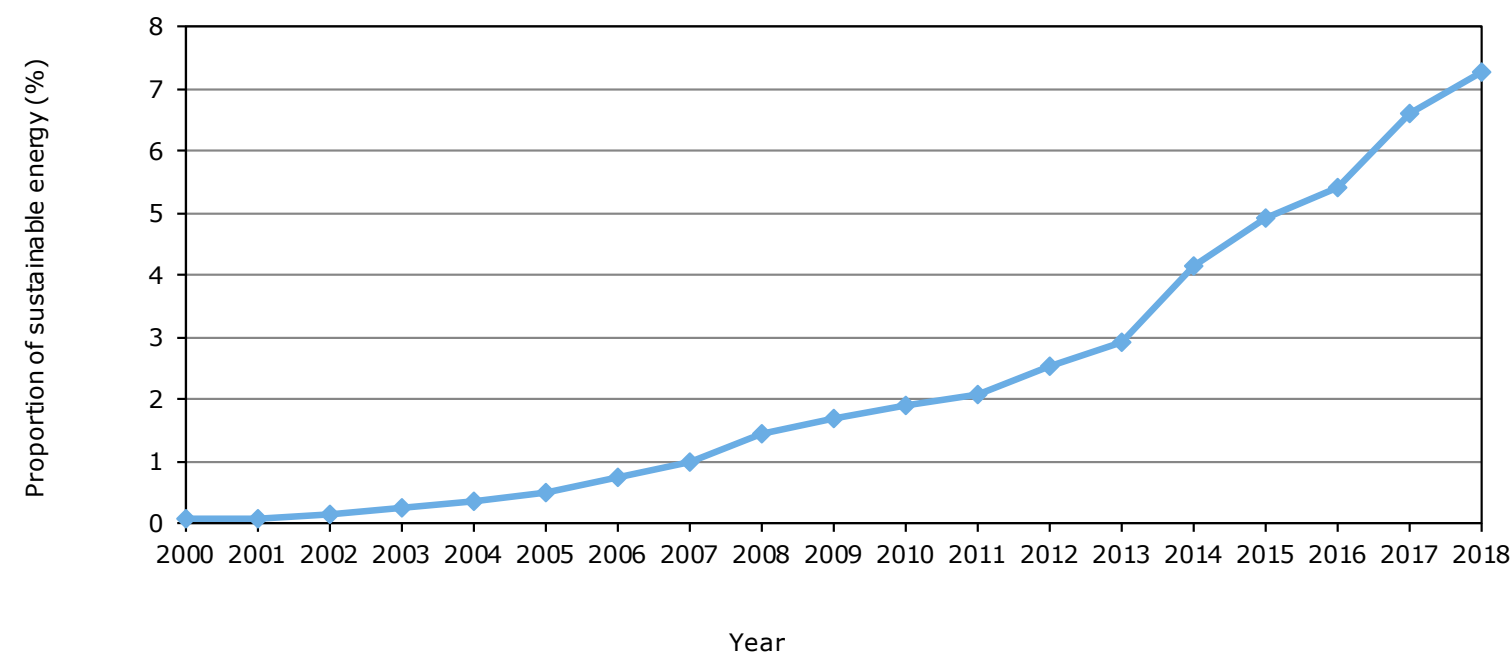

Figure S.2 Proportion of sustainable energy a)

a) Data for 2018 are provisional.

In 2018 , geothermal energy provided $48 \%$ of the sustainable energy, followed at a distance by purchases of sustainable electricity $(20 \%)$, solar energy $(11 \%)$, biofuels $(10 \%)$ and purchase of sustainable heat $(10 \%)$. The purchase of sustainable gas $(<1 \%)$ was also limited in 2018 . The use of geothermal heat and the purchase of sustainable heat both increased, while the purchase of sustainable electricity decreased.

About $80 \%$ of sustainable energy consumption consisted of sustainable heat and $20 \%$ of sustainable electricity. Regarding sustainable heat, $87 \%$ was self-produced, while $96 \%$ of sustainable electricity was purchased. The production area with sustainable energy (excluding purchase from public networks) increased to almost 1,500 ha in 2018 . This is $17 \%$ of the total production area. Sustainable energy is mainly used in larger greenhouses. Without the use of sustainable energy, the $\mathrm{CO}_{2}$ emissions from greenhouse horticulture in 2018 would have been 0.32 Mtonne higher. 
More energy sources without $\mathrm{CO}_{2}$ emissions and more purchases of $\mathrm{CO}_{2}$

Between 2010 and 2018 the proportion of natural gas in the energy supply decreased from $88 \%$ to $81 \%$. The energy supply of greenhouse horticulture has thus remained largely dependent on natural gas, but the first steps to lessen this dependence were taken (see Section 2.8). If energy sources without $\mathrm{CO}_{2}$ emissions are used, $\mathrm{CO}_{2}$ must also be obtained externally to safeguard crop growth. In 2018 the use of external $\mathrm{CO}_{2}$ sources grew by almost $10 \%$ to 0.64 Mtonne.

Proportion of heat from sustainable sources

The average proportion of heat from sustainable sources - expressed in natural gas equivalent (NGE) - was $15 \mathrm{~m}^{3} \mathrm{NGE} / \mathrm{m}^{2}$. This was lower than the averages for purchased heat $\left(23 \mathrm{~m}^{3} \mathrm{NGE} / \mathrm{m}^{2}\right)$ and natural gas $\mathrm{CHP}\left(22 \mathrm{~m}^{3} \mathrm{NGE} / \mathrm{m}^{2}\right)$, and also showed a decreasing trend. As a result, the use of sustainable heat sources can be constrained in the long term (see Chapter 5). To reduce $\mathrm{CO}_{2}$ emissions at sector level, however, increased proportions of both sustainable heat and purchased heat are required. Points for attention in this regard are the cost-effectiveness of the incentives for sustainable energy production when applying for SDE subsidy, spreading the project risk between the financing sources and the project partners and the availability of $\mathrm{CO}_{2}$. Combining multiple heat sources without $\mathrm{CO}_{2}$ emissions on the same crop production area is an additional challenge.

\section{Energy efficiency has also remained stable}

Relative to 1990, the energy efficiency of crop production, calculated as primary fuel consumption per unit of product, was $42 \%$ and has remained stable since 2010 . This is because the primary fuel consumption per $\mathrm{m}^{2}$ increased in step with the physical production per $\mathrm{m}^{2}$. In 2018 , both decreased by more than $1 \%$. In the years before, both increased by around $2 \%$ per year. The decrease in physical production in 2018 was probably related to the unusually warm summer. The decrease in primary fuel consumption in 2018 was mainly due to an increase in electricity sales from natural gas $\mathrm{CPH}$ (see Section 2.3).

Viewed over a longer period, the development of physical production is inhibited by the pursuit of higher value per unit of product through quality and delivery planning (see Section 2.3).

\section{Energy consumption and costs}

After increasing between 2014 and 2017, total energy consumption decreased in 2018 to 100.5 PJ, and consisted of approximately $74 \%$ heat and $26 \%$ electricity. In 2010 the proportions were $90 \%$ heat and $10 \%$ electricity. After declining between 2010 and 2014 by $10 \%$, energy consumption per $\mathrm{m}^{2}$ greenhouse increased between 2014 and 2018 by 7\%. This increase was larger for electricity consumption $(+22 \%)$, but heat consumption also increased $(+3 \%)$. The shift to electricity and the increase in electricity consumption was mainly due to increased use of supplemental lighting. Electricity sales amounted to 5.6 billion $\mathrm{kWh}$ in 2018. The costs of purchased energy increased more than revenue from energy sales, which led to an increase in net energy costs (expressed in $€ / \mathrm{m}^{2}$ ) in 2018.

\section{Combined heat and power (CHP)}

The total capacity of CHP plants has remained stable (about 2,400 MW) since 2015, and was somewhat smaller than in the years before. This is mainly due to the decreased production area. In 2018, a CHP plant was used on about $63 \%$ of the production area. The average duration of CHP use increased in 2017 and 2018, and was nearly 3,900 hours in 2018, which is almost 20\% more than in 2016. This is due to an improved spark spread (the ratio between the sales price of electricity and the purchase price of natural gas), both in 2017 and 2018. CHP production in 2018 was more than 9 billion kWh. This is 1.2 billion kWh more than in 2016. In 2018, CHP in the greenhouse horticulture sector provided nearly $8 \%$ of the national electricity consumption. As a result of electricity production with $\mathrm{CHP}$, the $\mathrm{CO}_{2}$ emissions of greenhouse horticulture were 2.6 Mtonnes higher in $2018, \mathrm{CO}_{2}$ emissions of central power plants were reduced by 4.2 Mtonnes, and on balance $1.6 \mathrm{Mtonnes}$ of $\mathrm{CO}_{2}$ emissions were avoided at the national level. However as a result of IPCC method this avoidance is not expressed in the $\mathrm{CO}_{2}$ emissions of greenhouse horticulture because emissions are attributed to the emitter and not to the consumer of energy. 
Electricity demand and supply

Electricity consumption by greenhouse horticulture has been increasing since 2010 and was estimated to be at 6.7 billion $\mathrm{kWh}$ in 2018 . This is $5.5 \%$ of national consumption. The increase is mainly due to the increase in the use of artificial growth light. After increasing by about $20 \%$ between 2010 and 2017, purchases of electricity stabilised in 2018 at 2.8 billion kWh. The reasons for this are not entirely clear. The proportion of electricity demand that was generated with CHP decreased from $62 \%$ in 2014 to $57 \%$ in 2018 . This is related to the intensification in the use of supplemental lighting per $\mathrm{m}^{2}$ in combination with the constraints of utilisation of CHP heat.

Purchased heat

In 2018, purchased heat (excluding sustainable heat) for greenhouse horticulture decreased by $0.3 \mathrm{PJ}$ to 3.4 PJ. The decrease was due to the larger proportion of sustainable heat in the total purchase of heat which counts with sustainable energy. Between 2010 and 2018, purchased heat decreased from 5.3 to 3.4 PJ. In 2018, the proportion of purchased heat in total energy consumption in the sector was $3.4 \%$. Purchased heat reduced the $\mathrm{CO}_{2}$ emissions of greenhouse horticulture in 2018 by 0.14 Mtonne.

\section{S.3 Method}

Commissioned by Stichting Kennis in je Kas (Greenhouse research funding Foundation) of the greenhouse horticulture sector and the Ministry of Agriculture, Nature and Food Quality, Wageningen Economic Research annually quantifies the development of the energy indicators. These indicators consist of $\mathrm{CO}_{2}$ emissions, energy efficiency and the proportion of sustainable energy in greenhouse horticulture. This is worked out by mapping out the energy balance an physical production. A methodology has been developed for the Greenhouse Horticulture Energy Monitor, which sector experts use to combine a range of data sources. To specify the quantifications, backgrounds are analysed. The methodology is laid down in a protocol. 


\section{$1 \quad$ Inleiding}

\subsection{Beleidsmatige context}

\section{Meerjarenafspraak Energietransitie Glastuinbouw}

Tussen de Nederlandse glastuinbouw en de Nederlandse overheid is in 2014 de Meerjarenafspraak Energietransitie Glastuinbouw 2014-2020 gemaakt. Deze afspraak bouwt voort op het Convenant $\mathrm{CO}_{2}$ emissieruimte binnen het $\mathrm{CO}_{2}$-sectorsysteem glastuinbouw. In beide convenanten staat de totale $\mathrm{CO}_{2}-$ emissie centraal. Het doel in de Meerjarenafspraak is een maximale totale $\mathrm{CO}_{2}$-emissie van 6,2 Mton in 2020 en is een onderdeel van de Nederlandse taakstelling voor het Europese doel om in $202020 \%$ minder $\mathrm{CO}_{2}$ uit te stoten in vergelijking met 1990.

\section{Technische correctie}

De $\mathrm{CO}_{2}$-emissie van de glastuinbouw daalde in de periode 2010-2015 sterk (Van der Velden en Smit, 2017b) en de prognose van de $\mathrm{CO}_{2}$-emissie in 2020 voorzag een verdere daling (Van der Velden en Smit, 2016). Deze voorziene daling van de $\mathrm{CO}_{2}$-emissie kwam voor een belangrijk deel door krimp van het areaal en minder verkoop van elektriciteit vanuit wkk. Deze ontwikkelingen waren geen resultaat van inspanning door de glastuinbouw maar van ontwikkelingen op de markt van tuinbouwproducten en de energiemarkt. De convenantspartijen hebben daarom, conform de afspraken in het convenant, besloten om de $\mathrm{CO}_{2}$-emissieruimte c.q. het $\mathrm{CO}_{2}$-doel voor de glastuinbouw in 2020 technisch te corrigeren (Brief, 2017) naar 4,6 Mton $^{1}$.

\section{Voorgaande convenanten}

In eerdere convenanten waren ook doelen opgenomen over de energie-efficiëntie, het aandeel duurzame energie, de $\mathrm{CO}_{2}$-emissie van de teelt en de reductie van de $\mathrm{CO}_{2}$-emissie door warmtekrachtkoppeling (wkk). In de Meerjarenafspraak van 2014 zijn deze doelen weliswaar verlaten, maar het blijven pijlers om de $\mathrm{CO}_{2}$-emissie te verlagen. Het blijft daarom belangrijk om ook de ontwikkeling van deze indicatoren in beeld te brengen.

\section{Programma Kas als Energiebron}

Om het doel van de Meerjarenafspraak te bereiken, werken glastuinbouw en rijksoverheid samen in het programma Kas als Energiebron (KaE). De ambities van KaE zijn dat vanaf 2020 in nieuwe kassen op economisch rendabele wijze netto-klimaatneutraal geproduceerd kan worden en dat dit in bestaande kassen met de helft van de fossiele brandstof ten opzichte van 2011 kan. Voor 2050 heeft $\mathrm{KaE}$ de ambitie dat de glastuinbouw een volledig duurzame en economisch rendabele energievoorziening zonder $\mathrm{CO}_{2}$-emissie heeft. De glastuinbouw heeft hiernaast zelf de ambitie uitgesproken om al in 2040 geen $\mathrm{CO}_{2}$ meer uit te stoten.

\section{$\mathrm{CO}_{2}$-emissie}

De $\mathrm{CO}_{2}$-emissie in de Meerjarenafspraak heeft betrekking op de absolute uitstoot van $\mathrm{CO}_{2}$. Deze wordt bepaald met de IPCC-methode (Intergovernmental Panel on Climate Change) en heeft alleen betrekking op het fossiele brandstofverbruik van de glastuinbouw op locatie. In- en verkoop van energie (elektriciteit en warmte) tellen niet mee. In de Energiemonitor wordt bij de $\mathrm{CO}_{2}$-emissie, voor een beter begrip en duiding, onderscheid gemaakt tussen totale $\mathrm{CO}_{2}$-emissie en $\mathrm{CO}_{2}$-emissie van de teelt. Het verschil is de emissie die samenhangt met de verkoop van elektriciteit uit aardgasgestookte wkk. Het doel van de Meerjarenafspraak heeft betrekking op de totale $\mathrm{CO}_{2}$-emissie. De uitstoot van andere broeikasgassen valt buiten de Meerjarenafspraak en deze monitor.

\section{Energie-efficiëntie}

De energie-efficiëntie is een relatieve indicator, gedefinieerd als het primair brandstofverbruik per geproduceerde eenheid (tuinbouw)product. Het primair brandstofverbruik is de fossiele brandstof die

\footnotetext{
1 In 2019 wordt hiervoor een nieuwe analyse gemaakt.
} 
nodig is voor de productie van de energie-input, verminderd met de fossiele brandstof die elders wordt uitgespaard door energie-output van de glastuinbouw. Bij het primair brandstofverbruik worden naast de input van fossiele brandstof dus ook de overige energie-input en -output in beschouwing genomen. Het primair brandstofverbruik wordt vervolgens in relatie gebracht met de omvang van de fysieke tuinbouwproductie waarvoor de brandstof is ingezet.

\section{Aandeel duurzame energie}

Het aandeel duurzame energie is net als de energie-efficiëntie een relatieve indicator. Het is het gebruik van duurzame energie ten opzichte van het totale netto-energiegebruik van de glastuinbouw, uitgedrukt in procenten. Het totale netto-energiegebruik en de hoeveelheid duurzame energie worden bepaald op basis van de energie-inhoud van de energie-input en -output.

\section{Protocol}

De definities van de indicatoren, de methodiek en de gebruikte bronnen voor de monitor zijn vastgelegd in het Protocol Energiemonitor Glastuinbouw (Van der Velden en Smit, 2019d) en zijn in bijlage 1 op hoofdlijnen toegelicht. In dit protocol wordt onderscheid gemaakt tussen de conceptuele methodiek en de werkwijze. De werkwijze kan in de loop der jaren wijzigen, onder andere door beschikbaarheid van databronnen en mutaties in omrekeningsfactoren. Daardoor wordt jaarlijks een update van het Protocol gepubliceerd met mutaties en verbeteringen in de werkwijze.

\section{$\mathrm{CO}_{2}$-emissieruimte}

Naast het doel in de Meerjarenafspraak bestaat er voor de glastuinbouw een $\mathrm{CO}_{2}$-sectorsysteem. In het Convenant $\mathrm{CO}_{2}$-emissieruimte binnen het $\mathrm{CO}_{2}$-sectorsysteem glastuinbouw is een totale $\mathrm{CO}_{2}$-emissieruimte van 6,2 Mton in 2020 afgesproken (brief, 2017). Dit is inclusief de verkoop van elektriciteit. De 6,2 Mton komt overeen met het oorspronkelijke doel in de Meerjarenafspraak. Ook de $\mathrm{CO}_{2}$-emissieruimte voor 2020 is in 2017 gecorrigeerd naar 4,6 Mton.

In de jaren dat de $\mathrm{CO}_{2}$-emissie van de glastuinbouw boven de emissieruimte zit, dienen er door de glastuinbouwsector via de overheid $\mathrm{CO}_{2}$-emissierechten te worden aangeschaft. De kosten hiervoor worden door de sector opgebracht middels het $\mathrm{CO}_{2}$-sectorsysteem. In dit systeem worden deze kosten omgeslagen naar de individuele bedrijven. Als de sector het $\mathrm{CO}_{2}$-doel niet haalt, dan wordt de extra $\mathrm{CO}_{2}$-emissie dus via het $\mathrm{CO}_{2}$-sectorsysteem gecompenseerd.

\subsection{Glastuinbouw en energie}

\section{Ontwikkeling $\mathrm{CO}_{2}$-emissie}

De $\mathrm{CO}_{2}$-emissie van de glastuinbouw wordt beïnvloed door zeven factoren (Van der Velden en Smit, 2017). Deze factoren zijn: verschillen in de jaarlijkse buitentemperatuur, de omvang van de sector (areaal kassen), veranderingen in de energie-input en-output (verkoop elektriciteit, gebruik duurzame energie, inkoop warmte en inkoop elektriciteit), en de energievraag per $\mathrm{m}^{2}$. Achter de energievraag per $\mathrm{m}^{2}$ zitten de processen intensivering en extensivering van de teelt (toename en afname van de energievraag per $\mathrm{m}^{2}$ ) en energiebesparing (afname van de energievraag per $\mathrm{m}^{2}$ ).

\section{Areaal kassen}

Het areaal kassen is van invloed op de totale $\mathrm{CO}_{2}$-emissie van de sector. De ontwikkeling van het areaal is afhankelijk van de vraag naar de afzonderlijke Nederlandse glastuinbouwproducten en van de fysieke productie per $\mathrm{m}^{2}$ kas.

\section{Intensivering}

De energievraag verandert door intensivering en extensivering. Het gematigde klimaat in Nederland met relatief zachte winters en relatief koele zomers is gunstig voor de teelt van glastuinbouwproducten. De Nederlandse glastuinbouw kenmerkt zich door een hoge fysieke productie en waarde en dito kosten per $\mathrm{m}^{2}$ kas. Door internationale concurrentie is in de Nederlandse glastuinbouw een continu proces van intensivering gaande om de hoge productie en waarde van de producten in stand te houden en uit te bouwen. Intensivering is een economisch gedreven proces dat ook leidt tot een toename van de energiebehoefte. Voortdurende innovatie van kassen, teeltsystemen en andere technologische 
hulpmiddelen zijn vooral gericht op verdere optimalisatie van de teeltomstandigheden. Hiermee richt de sector zich op het jaarrond leveren van kwaliteitsproducten om te beantwoorden aan de vraag vanuit de topsegmenten van de internationale markt. Dit leidt tot meer gewassen met een grotere energiebehoefte, maar ook tot toenemende productie in de winterperiode met groeilicht. Intensivering brengt hierdoor een hogere energievraag per $\mathrm{m}^{2}$ kas met zich mee.

\section{Extensivering}

Naast intensivering vinden er ontwikkelingen plaats waardoor er juist minder energie-intensieve gewassen worden geteeld, bijvoorbeeld door een verminderde vraag vanuit de markt naar energieintensieve gewassen. Door veranderingen in de sectorstructuur (areaal per gewas) kan het gemiddelde energiegebruik per $\mathrm{m}^{2}$ kas dalen, in dat geval is er sprake van extensivering. Daarnaast kan er minder intensief worden geteeld door bijvoorbeeld stijging van de energiekosten.

\section{Energiebesparing}

Naast extensivering kan de energievraag per $\mathrm{m}^{2}$ kas ook dalen door energiebesparing. Voorbeelden hiervan zijn nieuwe kassen, (extra) energieschermen, efficiëntere lampen (led-licht) en energiezuinige teeltstrategieën zoals Het Nieuwe Telen (HNT). HNT is een innovatieve energiezuinige teeltstrategie voor regeling van het kasklimaat waarbij gebruik wordt gemaakt van natuur- en plantkundige kennis om de teelt optimaal te sturen voor wat betreft temperatuur, vocht, $\mathrm{CO}_{2}$-niveau, licht en het gebruik van schermen. HNT ontwikkelt zich verder en staat door een positieve invloed op de teelt sterk in de belangstelling.

\section{Effecten $\mathrm{CO}_{2}$-emissie}

Een onderzoek naar de effecten van intensivering, extensivering en energiebesparing op de $\mathrm{CO}_{2}$ emissie in de periode 2020-2015 door Wageningen Economic Research is in 2017 gepubliceerd (Van der Velden en Smit, 2017). Op de bevindingen wordt in paragraaf 2.5 voortgebouwd in de kwantitatieve analyse van de ontwikkeling van de $\mathrm{CO}_{2}$-emissie.

\section{Energievoorziening zonder $\mathrm{CO}_{2}$-emissie}

Naast de energievraag is de wijze waarop in de energievraag wordt voorzien van grote invloed op de ontwikkeling van de $\mathrm{CO}_{2}$-missie van de glastuinbouw. Warmte uit aardgasgestookte ketels is al lange tijd niet meer de belangrijkste energievoorziening. Door de tuinders wordt een mix ingezet van wkk, ketels, duurzame energiebronnen en inkoop van warmte en elektriciteit. Ook wordt er elektriciteit en in geringe mate warmte verkocht.

Door het gebruik van duurzame energie en de inkoop van warmte en elektriciteit bestaat een deel van energievoorziening uit bronnen zonder fossiel brandstofverbruik c.q. $\mathrm{CO}_{2}$-emissie van de glastuinbouw. Voorbeelden van duurzame energiebronnen in de glastuinbouw zijn aardwarmte, zonne-energie, biobrandstof en inkoop duurzame warmte en elektriciteit.

\subsection{De Energiemonitor}

In de Energiemonitor van de Nederlandse Glastuinbouw wordt de ontwikkeling van de totale $\mathrm{CO}_{2}-$ emissie gekwantificeerd en geanalyseerd. Ook worden de achterliggende indicatoren $\mathrm{CO}_{2}$-emissie van de teelt, energie-efficiëntie en het aandeel duurzame energie gekwantificeerd en geanalyseerd. Als basis hiervoor wordt de energiebalans van de glastuinbouw opgesteld. De energiebalans omvat de energie-input en de energie-output van de sector. Daarnaast wordt de elektriciteitsbalans (inkoop, verkoop, productie en consumptie) globaal in kaart gebracht. Om de energie-efficiëntie te kunnen bepalen, wordt ten slotte ook de ontwikkeling van de fysieke productie van de glastuinbouw gekwantificeerd. 
Deze rapportage bevat de definitieve resultaten tot en met 2017 en - op basis van de medio 2019 beschikbare informatie - de voorlopige resultaten van $2018^{2}$. Door het gebruik van aanvullende databronnen zijn enkele eerder gepubliceerde resultaten over voorgaande jaren aangepast.

De ontwikkeling van de $\mathrm{CO}_{2}$-emissie, de achterliggende indicatoren en de factoren van invloed op de ontwikkeling komen aan bod in hoofdstuk 2. In hoofdstuk 3 is het gebruik van duurzame energie nader geanalyseerd. Warmtekrachtkoppeling, warmte-inkoop en de elektriciteitsbalans van de glastuinbouw zijn nader geanalyseerd in hoofdstuk 4. In hoofdstuk 5 volgt de reflectie. Ten slotte bevat hoofdstuk 6 de conclusies.

2 De voorlopige resultaten over 2018 worden een jaar later definitief gemaakt. In de achterliggende jaren gaf dit weinig verschil. Hierop was het voorlopige resultaat van de $\mathrm{CO}_{2}$-emissie van 2017 (5,9 Mton) een uitzondering en is als definitief resultaat in deze rapportage bijgesteld naar 5,7 Mton. 


\section{Ontwikkeling indicatoren}

\section{$2.1 \quad$ Inleiding}

In dit hoofdstuk wordt de ontwikkeling van de energie-indicatoren op sectorniveau behandeld. In de volgende paragraaf is dat de $\mathrm{CO}_{2}$-emissie. Hierna komen de energie-efficiëntie en het aandeel duurzame energie aan bod. De kwantitatieve effecten van de invloedsfactoren op de totale $\mathrm{CO}_{2}$ emissie, de energiekosten, het energiegebruik en het aandeel van de energievoorziening zonder $\mathrm{CO}_{2}$ emissie komen in de vier paragrafen daarna aan bod. De betekenis voor het $\mathrm{CO}_{2}$-doel voor 2020 is het onderwerp van de reflectie in hoofdstuk 5.

\section{$2.2 \quad \mathrm{CO}_{2}$-emissie}

Totale $\mathrm{CO}_{2}$-emissie

De $\mathrm{CO}_{2}$-emissie lag in 2018 met 5,7 Mton in 2018 0,5 Mton (8\%) onder het oorspronkelijke doel van 6,2 Mton voor 2020 in de Meerjarenafspraak. In vergelijking met het $\mathrm{CO}_{2}$-doel voor 2020 na technische correctie (4,6 Mton) lag de $\mathrm{CO}_{2}$-emissie in 2018 24\% hoger en zou de emissie met nog 1,1 Mton moeten worden gereduceerd. De totale $\mathrm{CO}_{2}$-emissie van de glastuinbouw is vanaf 2015 stabiel op het niveau van 5,7 Mton per jaar (figuur 2.1). De stabilisering volgde na een sterke daling van 2,4 Mton in de periode 2010-2014. De $\mathrm{CO}_{2}$-emissie lag in 2018 1,1 Mton (16\%) lager dan in 1990 (6,8 Mton).

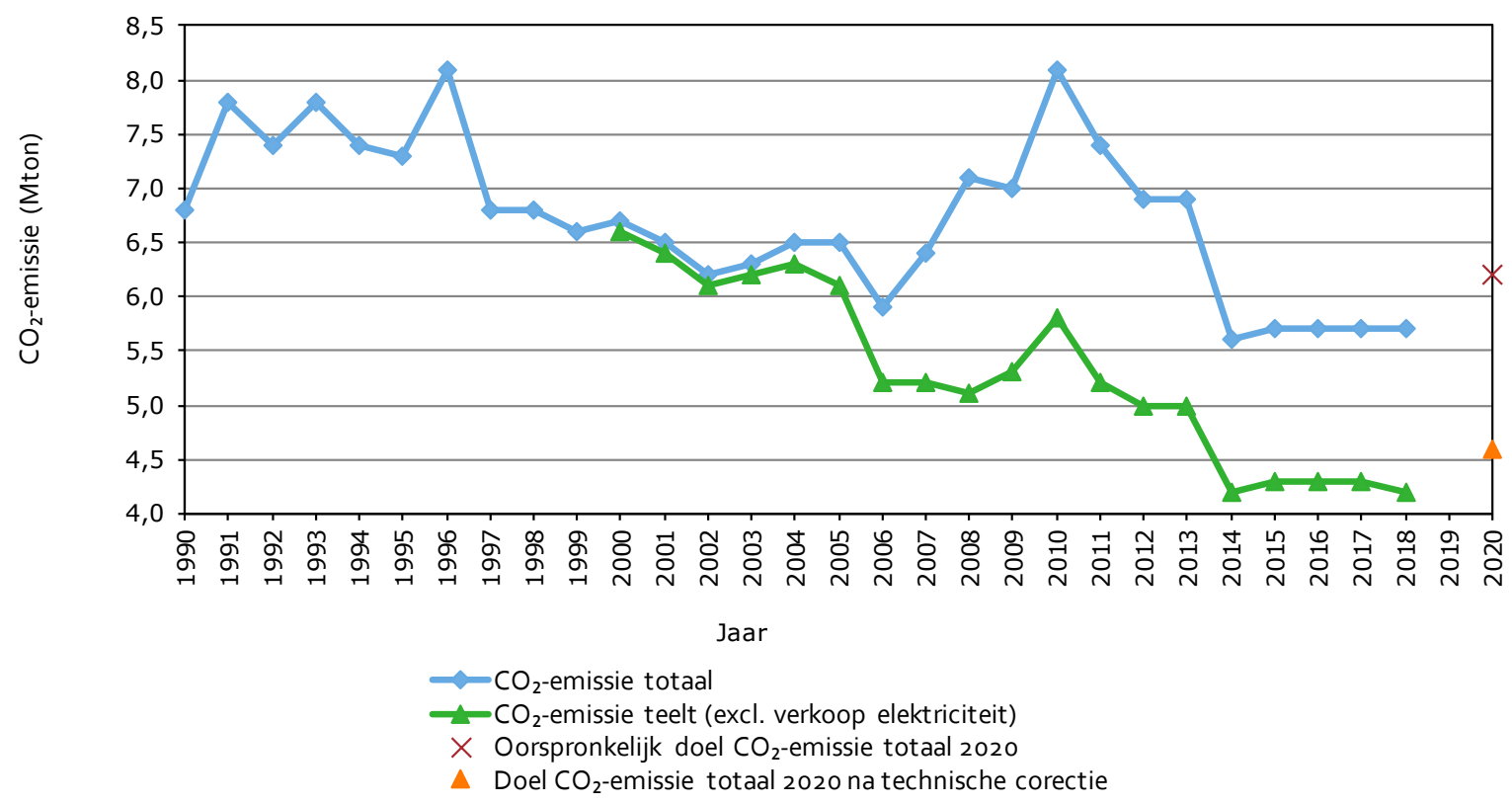

Figuur 2.1 $\mathrm{CO}_{2}$-emissie van de glastuinbouw per jaar a)

a) Cijfers 2018 voorlopig.

$\mathrm{CO}_{2}$-emissie teelt

De $\mathrm{CO}_{2}$-emissie van de teelt ligt lager dan de totale $\mathrm{CO}_{2}$-emisie omdat de elektriciteitsverkoop wordt verrekend. De $\mathrm{CO}_{2}$-emissie van de teelt daalde in 2018 licht en was over een langere periode bezien ook stabiel (figuur 2.1). De $\mathrm{CO}_{2}$-emissie van de teelt lag in 2018 op 4,2 Mton. Dit is 2,6 Mton (39\%) onder de emissie van 1990. Het verschil tussen de totale $\mathrm{CO}_{2}$-emissie en de $\mathrm{CO}_{2}$-emissie van de teelt 
is in de periode 2010-2016 kleiner geworden en bedroeg in 2016 1,3 Mton. Dit kwam door vermindering van de verkoop van elektriciteit vanuit wkk en een toename van de consumptie van elektriciteit vanuit wkk. Net als in 2017 nam de elektriciteitsverkoop in 2018 weer toe (paragraaf 4.2.2). Hierdoor is ook het verschil tussen de totale $\mathrm{CO}_{2}$-emissie en de $\mathrm{CO}_{2}$-emisssie van de teelt weer toegenomen tot een niveau van 1,5 Mton in 2018.

\section{Temperatuurcorrectie}

De $\mathrm{CO}_{2}$-emissie wordt volgens de definitie niet gecorrigeerd voor buitentemperatuur. Alle jaren in de periode 2014 tot en met 2018 waren relatief warm. Als de $\mathrm{CO}_{2}$-emissie wel gecorrigeerd zou worden voor de buitentemperatuur, dan zou de totale $\mathrm{CO}_{2}$-emissie over de periode 2014-2018 met 0,1 Mton zijn gedaald tot 5,8 Mton in 2018 (bijlage 2). Over de gehele periode 2015-2018 was ook de totale $\mathrm{CO}_{2}$-emissie na temperatuurcorrectie stabiel. De jaarlijkse fluctuaties zijn na temperatuurcorrectie wat groter.

\section{$\mathrm{CO}_{2}$-emissie Nederland}

Voor Nederland als geheel kwam de $\mathrm{CO}_{2}$-emissie in 2018 uit op 161,2 Mton (CBS Statline, bijlage 2). Dit is $1 \%$ minder dan in 1990 . In de glastuinbouw ligt de totale $\mathrm{CO}_{2}$-emissie in $201816 \%$ onder het niveau van 1990 en de $\mathrm{CO}_{2}$-emissie van de teelt ligt daar 39\% onder. De glastuinbouw doet het bij het terugdringen van de $\mathrm{CO}_{2}$-emissie dus beter dan de landelijke ontwikkeling. Dit terwijl de sector een substantiële hoeveelheid elektriciteit met wkk op aardgas is gaan produceren en verkopen.

\section{Warmtekrachtkoppeling}

De glastuinbouw produceerde in 2018 circa 9,4 miljard kWh elektriciteit met aardgas-wkk (hoofdstuk 4). Dit is 0,9 miljard (8\%) minder dan in 2012, het jaar met de hoogste elektriciteitsproductie. In de periode 2012-2016 daalde de productie met ruim 2 miljard kWh om in de jaren 2017 en 2018 weer toe te nemen met 1,2 miljard kWh. Met de productie in 2018 werd op nationaal niveau op basis van het primair brandstofverbruik (paragraaf 2.3) 0,9 Mton $\mathrm{CO}_{2}$-emissie vermeden. Deze vermeden $\mathrm{CO}_{2}-$ emissie kwam voort uit efficiëntere elektriciteitsproductie. Hierdoor werd een brandstofverbruik in elektriciteitscentrales van 2,3 miljard $\mathrm{m}^{3}$ aardgasequivalenten vermeden en nam per saldo het aardgasverbruik in de glastuinbouw met 1,4 miljard $\mathrm{m}^{3}$ toe. Dit laatste is het saldo van het extra aardgasverbruik in de wkk's minus het verminderde verbruik in de ketels.

\subsection{Energie-efficiëntie}

Net als de $\mathrm{CO}_{2}$-emissie is ook de energie-efficiëntie de laatste jaren stabiel (figuur 2.2). In 2015 en 2018 bedroeg de energie-efficiëntie 42\% ten opzichte van 1990 (bijlage 2). De glastuinbouw gebruikte daarmee in 2018 58\% minder primair brandstof per eenheid product dan in 1990. De stabilisatie van de energie-efficiëntie in 2018 kwam door afname van zowel het primair brandstofverbruik per $\mathrm{m}^{2}$ als van de fysieke productie per $\mathrm{m}^{2}$ met ruim $1 \%$.

Over een langere periode bezien is de energie-efficiëntie in de jaren 2015-2018 maar weinig verbeterd ten opzichte van de periode 2008-2014. Het verschil bedroeg circa 1 procentpunt. Dit betekent dat de energie-efficiëntie sinds 2010 vrijwel gelijk is gebleven. In de periode voor 2008 liet de energieefficiëntie nog een sterke verbetering zien. De afvlakking van de ontwikkeling komt mede door het nastreven van een hogere waarde per eenheid product en marktvraag gericht op productie in de winterperiode met belichting. Deze ontwikkeling remt de ontwikkeling van de fysieke productie en doet het primair brandstofverbruik toenemen. 


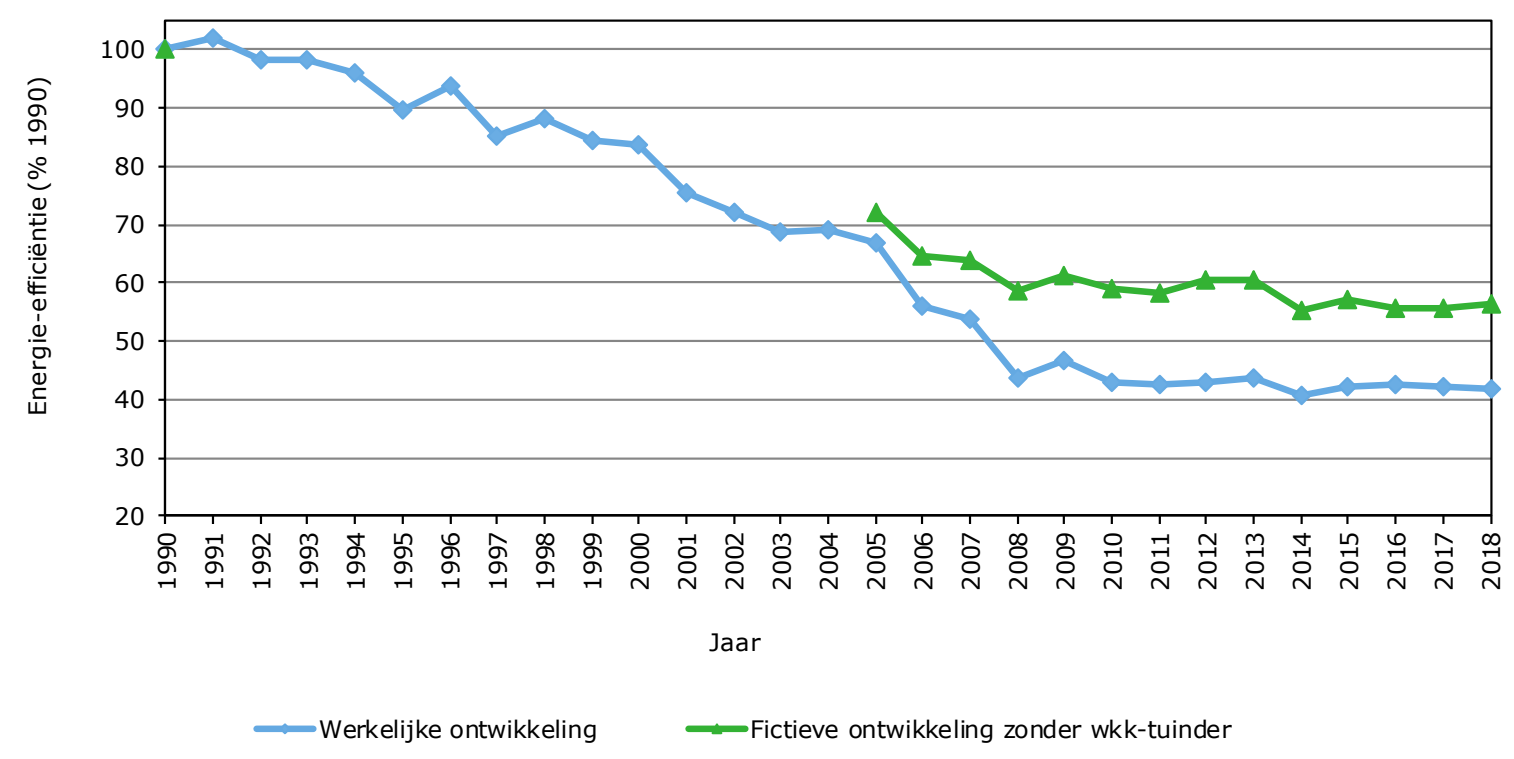

Figuur 2.2 Energie-efficiëntie in de productieglastuinbouw per jaar met en zonder wkk a) a) Cijfers 2018 voorlopig.

\section{Primair brandstof}

Het primair brandstofverbruik per $\mathrm{m}^{2}$ (figuur 2.3 en bijlage 2) daalde in de periode 2005-2008 sterk (minus $12 \mathrm{~m}^{3}$ a.e. $/ \mathrm{m}^{2}$ ). Dit kwam vooral door de sterke groei van het gebruik van wkk en het benutten van vrijkomende warmte bij deze vorm van elektriciteitsproductie (hoofdstuk 4). In de periode 2008-2017 nam het primair brandstofverbruik per $\mathrm{m}^{2}$ licht toe. Dit kwam vooral door daling van de elektriciteitsverkoop vanuit de wkk en door groei van het elektriciteitsconsumptie voor groeilicht vanuit wkk (paragraaf 2.6). In 2018 nam het primair brandstofverbruik per $\mathrm{m}^{2}$ iets af tot het niveau van 2016. Dit hangt samen met de toename van de verkoop van elektriciteit geproduceerd met aardgas wkk's.

\section{Fysieke productie}

Het jaar 2018 liet een afname van de fysieke productie zien. Dit hangt waarschijnlijk samen met de warme zomer en het verder nastreven van afstemming van de productie met de marktvraag. De fysieke productie per $\mathrm{m}^{2}$ vertoont vanaf 1990 een stijgende trend met verschillen tussen de jaren (figuur 2.3 en bijlage 2). Over de gehele periode 1990-2018 steeg de fysieke productie per $\mathrm{m}^{2}$ met $51 \%$. Dat is gemiddeld ruim 1,5\% per jaar. In de periode $1990-2008$ was dit bijna $2 \%$ per jaar. Vanaf 2008 vlakte de groei af. In de periode 2008-2018 was de groei gemiddeld 1,0\% per jaar. Dit hangt samen met de vraag vanuit de afzetmarkt. De vraag naar kwaliteitsproducten neemt toe. Bovendien is de periode van afzet van belang. Hierbij moet gedacht worden aan producten met een hogere waarde, jaarrond aanvoer en dus winterproductie met belichting en afzet van grote partijen op afgesproken momenten. De glastuinbouwondernemers anticiperen hierop. Deze ontwikkeling van waardegerichte groei in plaats van volumegerichte groei gaat ten koste van de ontwikkeling van de fysieke productie. 


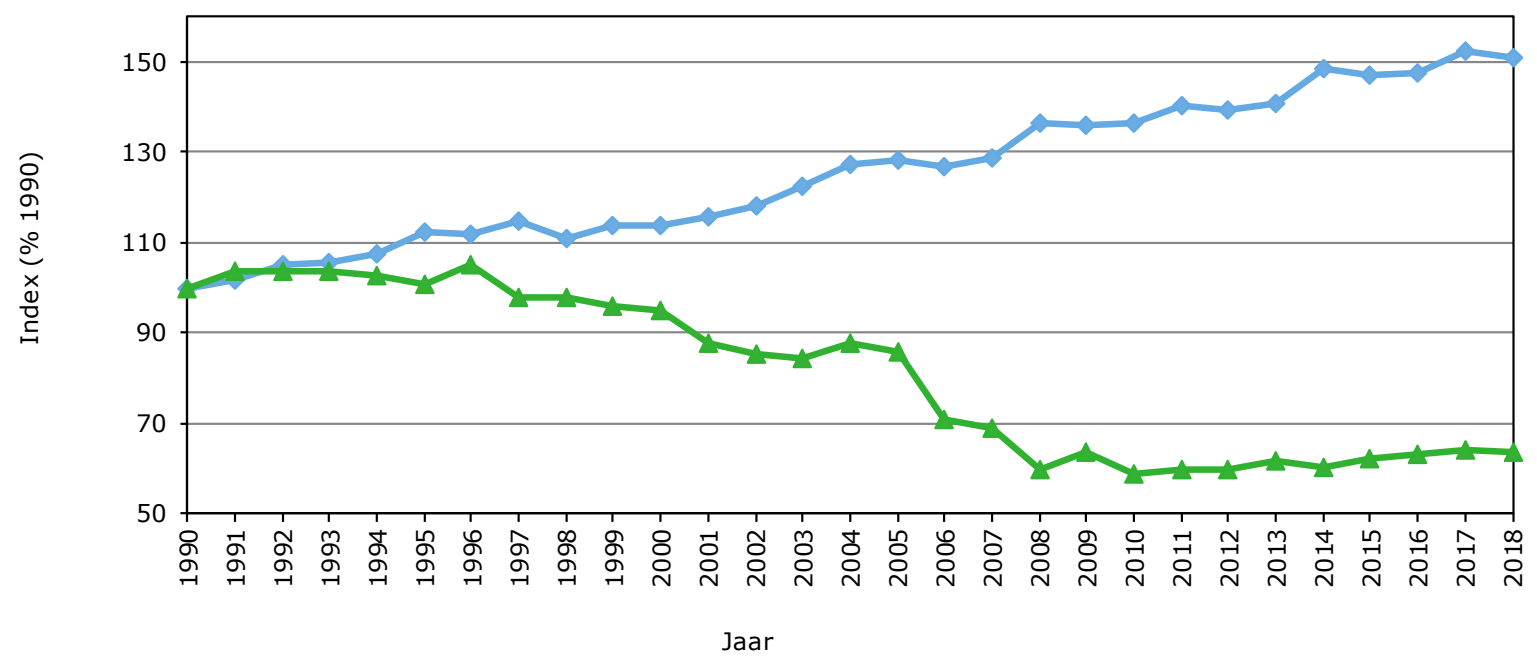

$\longrightarrow$ Index fysieke productie per $\mathrm{m}^{2} \quad$ - Index primair brandstofverbruik per $\mathrm{m}^{2}$

Figuur 2.3 Fysieke productie en primair brandstofverbruik in de productieglastuinbouw per $\mathrm{m}^{2}$ kas a) a) Cijfers 2018 voorlopig.

\section{Effect warmtekrachtkoppeling}

Het gebruik van wkk heeft een positief effect op het primair brandstofverbruik en dus op de energieefficiëntie, omdat bij de productie van elektriciteit ook de vrijkomende warmte en $\mathrm{CO}_{2}$ nuttig kunnen worden ingezet. Dit in tegenstelling tot elektriciteitsproductie in centrales waar de vrijkomende warmte grotendeels wordt geloosd (hoofdstuk 4). In 2012 lag het positieve effect op de energieefficiëntie op ongeveer 18 procentpunten in vergelijking met een situatie zonder wkk (groene lijn in figuur 2.2). In de jaren daarna was het effect teruggelopen tot 13 procentpunten in 2016. Deze daling hangt samen met de verminderde elektriciteitsproductie door wkk. Dit kwam door een verslechterde spark spread voor wkk, ofwel de verhouding tussen de aardgasprijs (meer gestegen) en de elektriciteitsprijs (minder gestegen). Hierdoor werd er minder elektriciteit geproduceerd voor verkoop. Na 2016 nam het effect van wkk op de energie-efficiëntie weer toe tot $14 \%$ in 2018. De spark spread was in deze jaren gunstiger en de elektriciteitsverkoop nam toe. Hiernaast neemt de consumptie van de elektriciteit uit eigen productie door de glastuinbouw door groei van de inzet van groeilicht toe. Hierdoor blijft verbetering van de energie-efficiëntie onder druk staan.

\subsection{Aandeel duurzame energie}

Het aandeel duurzame energie in het totaal energiegebruik is in 2018 wederom toegenomen. Het aandeel groeide van 6,6 naar $7,3 \%$ (figuur 2.4). Het absolute gebruik van duurzame energie nam in 2018 toe van 6,7 naar 7,4 PJ. Dit is een toename met $9 \%$.

Zowel het absolute gebruik van duurzame energie als het aandeel in het totaal energiegebruik toont vanaf 2000 een toename. Vanaf 2013 is de toename sterker. De toename van het absolute gebruik van duurzame energie bedroeg vanaf 2013 circa 150\%, het aandeel nam met circa $120 \%$ toe.

In 2018 was de toename van het aandeel duurzaam iets groter dan van het absolute gebruik. Dit kwam doordat het gebruik van duurzame energie steeg en het totaal energiegebruik van de glastuinbouw in 2018 daalde (bijlage 2).

Voor Nederland als geheel bedroeg het aandeel duurzame energie in $20176,6 \%$ en in $20187,4 \%$ (CBS, Statline, bijlage 2). Voor de glastuinbouw waren deze aandelen $6,6 \%$ en $7,3 \%$. Het aandeel duurzame energie in de glastuinbouw komt daarmee bijna overeen met het landelijk aandeel (figuur 2.4). In 2010 was er nog een achterstand van 2 procentpunten. Het aandeel duurzame energie in de glastuinbouw groeide in de periode 2010-2017 dus sterker dan het aandeel van Nederland als geheel. 
Door de glastuinbouw toegepaste duurzame energie bestond voor circa $80 \%$ uit warmte en voor $20 \%$ uit elektriciteit. Het totaal wordt voor twee derde door de sector zelf geproduceerd en voor een derde ingekocht. Van de toegepaste duurzame warmte werd $87 \%$ door de sector zelf geproduceerd.

Toegepaste duurzame elektriciteit werd voor $96 \%$ ingekocht. De hoeveelheid duurzame energie die door de glastuinbouw werd verkocht aan afnemers buiten de sector was beperkt (hoofdstuk 3 ).

Het gebruik van duurzame energie had in 2018 een positief effect op de totale $\mathrm{CO}_{2}$-emissie op sectorniveau van ruim 0,3 Mton. Op de energie-efficiëntie was het effect ruim 4 procentpunten (paragraaf 3.4).

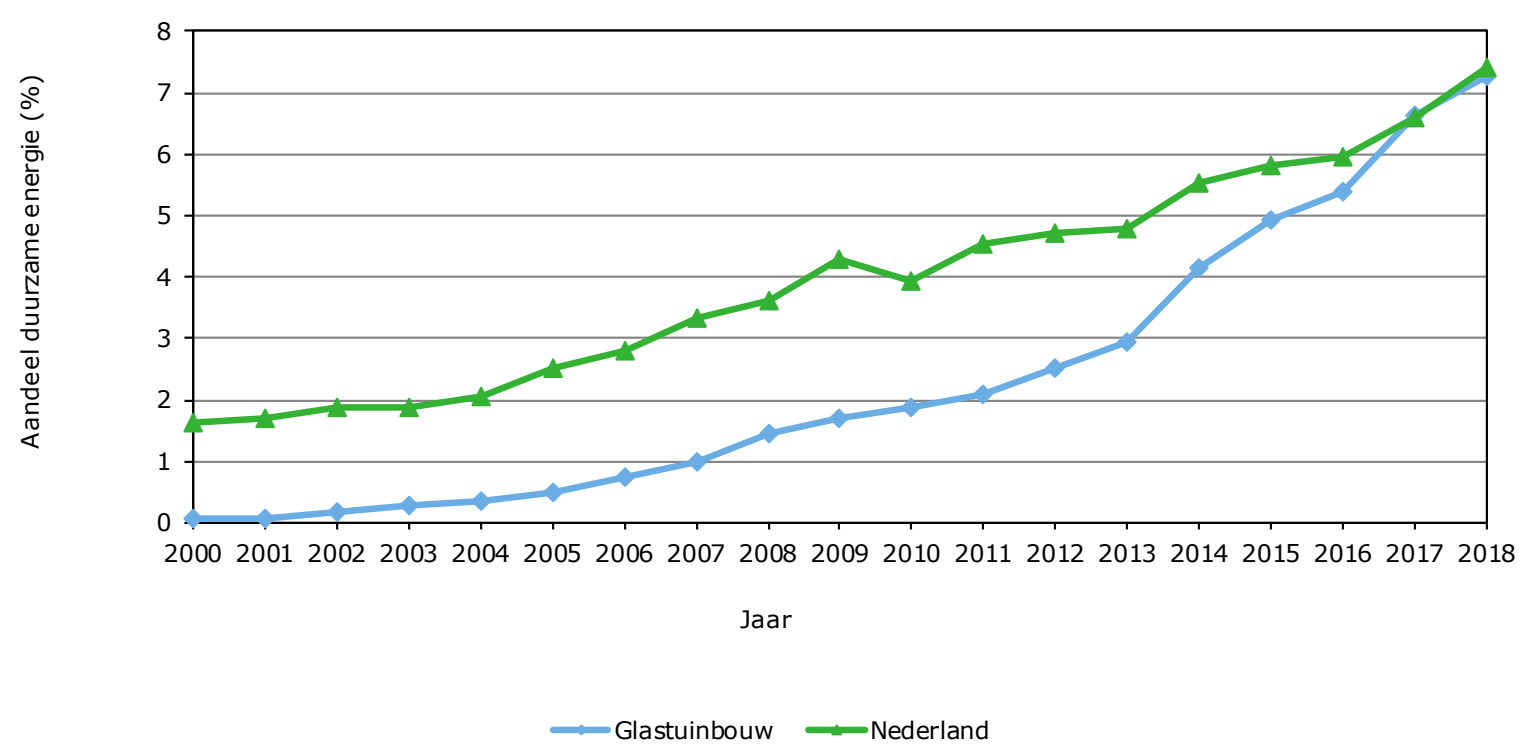

Figuur 2.4 Aandeel duurzame energie in de glastuinbouw en in Nederland per jaar a) a) Cijfers 2018 voorlopig.

\subsection{Kwantitatieve analyse ontwikkeling $\mathrm{CO}_{2}$-emissie}

\section{Inleiding}

In de periode 2010-2018 daalde de totale $\mathrm{CO}_{2}$-emissie van de glastuinbouw met 2,3 Mton. In de periode 2010-2014 nam de $\mathrm{CO}_{2}$-emissie met 2,4 Mton af en in de periode 2014-2018 met 0,1 Mton toe (figuur 2.1). In deze paragraaf worden de achtergronden van de ontwikkelingen in deze perioden kwantitatief geanalyseerd. Hierbij wordt de perioden 2010-2014 en 2014-2018 afzonderlijk in beschouwing genomen.

\section{Buitentemperatuur}

De jaren 2018 en 2014 waren relatief warm en 2010 relatief koud. Als voor de buitentemperatuur wordt gecorrigeerd, dan bedraagt de daling van de $\mathrm{CO}_{2}$-emissie in de periode 2010-2018 2,0 Mton in plaats van 2,3 Mton. Na temperatuurcorrectie is de $\mathrm{CO}_{2}$-emissie in 2010-2014 met 1,9 Mton afgenomen en in de periode 2014-2018 met 0,1 Mton. In de eerste periode was er dus een substantiële daling en in de tweede periode was de $\mathrm{CO}_{2}$-emissie dus min of meer stabiel.

De $\mathrm{CO}_{2}$-emissie na temperatuurcorrectie is het vertrekpunt voor de analyse van de effecten van de overige invloedsfactoren (tabel 2.1). Na de invloed van de buitentemperatuur wordt de ontwikkeling van de totale $\mathrm{CO}_{2}$-emissie bepaald door onderstaande invloedsfactoren:

1. areaal glastuinbouw

2. verkoop elektriciteit

3. gebruik duurzame energie

4. inkoop warmte 
5. inkoop elektriciteit

6. intensivering

7. extensivering

8. energiebesparing.

Analyse

Van de eerste 5 factoren is kwantitatieve informatie beschikbaar. De overige 3 factoren -

intensivering, extensivering en energiebesparing - bepalen de ontwikkeling van het energiegebruik per $\mathrm{m}^{2}$. Over deze factoren binnen de glastuinbouw is weinig kwantitatieve informatie beschikbaar. De ontwikkeling hiervan vindt immers gezamenlijk achter de energiemeters plaats. Het gezamenlijk effect is daarom als saldo gekwantificeerd. Door intensivering neemt het energiegebruik toe en door extensivering en energiebesparing neemt het energiegebruik af.

In de analyse van de effecten van de invloedsfactoren is onderscheid gemaakt naar de periode 20102014 en 2014-2018 (tabellen 2.1. en 2.2). Voor de inhoudelijke uitleg van de kwantificering van de effecten wordt verwezen naar de Energiemonitor Glastuinbouw 2017 (Van der Velden en Smit, 2017b) en de analyse van het effect van intensivering, extensivering en energiebesparing (Van der Velden en Smit, 2017).

Tabel 2.1 Ontwikkeling van de invloedsfactoren op de totale $\mathrm{CO}_{2}$-emissie van de glastuinbouw in de afzonderlijke perioden 2010-2018 (Mton)

\begin{tabular}{|c|c|c|c|c|c|c|}
\hline \multirow[t]{3}{*}{ Invloedsfactoren } & \multirow[t]{3}{*}{ Eenheid } & \multirow[t]{3}{*}{2010} & \multirow[t]{3}{*}{2014} & \multirow[t]{3}{*}{2018} & \multicolumn{2}{|c|}{ Verschil } \\
\hline & & & & & $2010 \mathrm{t} / \mathrm{m}$ & $2014 \mathrm{t} / \mathrm{m}$ \\
\hline & & & & & 2014 & 2018 \\
\hline Verkoop elektriciteit (wkk-aardgas) & miljard kWh & 8,4 & 5,2 & 5,6 & $-3,2$ & $+0,4$ \\
\hline $\begin{array}{l}\text { Duurzame energie (warmte } \\
\text { elektriciteit) }\end{array}$ & $\mathrm{PJ}$ & 2,4 & 4,0 & 7,3 & $+1,6$ & $+2,3$ \\
\hline Inkoop warmte (niet duurzaam) & PJ & 5,3 & 3,4 & 3,4 & $-1,9$ & 0,0 \\
\hline Inkoop elektriciteit (niet duurzaam) & miljard kWh & 2,0 & 2,1 & 2,4 & $+0,1$ & $+0,3$ \\
\hline
\end{tabular}

Tabel 2.2 Effect op $\mathrm{CO}_{2}$-emissie door de invloedsfactoren in de afzonderlijke perioden 2010-2018 (Mton) a)

\begin{tabular}{|c|c|c|c|}
\hline Invloedsfactoren & \multicolumn{3}{|c|}{ Periode } \\
\hline Areaal & $-0,66$ & $-0,42$ & $-0,24$ \\
\hline Duurzame energie & $-0,29$ & $-0,09$ & $-0,20$ \\
\hline Inkoop warmte (niet duurzaam) & $+0,11$ & $+0,11$ & $-0,00$ \\
\hline Subtotaal & $-1,72$ & $-1,28$ & $-0,44$ \\
\hline Energiegebruik per $\mathrm{m}^{2}$ & $-0,23$ & $-0,58$ & $+0,35$ \\
\hline Totaal & $-1,95$ & $-1,86$ & $-0,09$ \\
\hline
\end{tabular}

a) Na temperatuurcorrectie

Periode 2010-2014

De $\mathrm{CO}_{2}$-emissie daalde door krimp van het areaal (-0,42 Mton), daling van de verkoop van elektriciteit geproduceerd met de aardgas wkk's $(-0,86)$, toename van duurzame energie $(-0,09)$ en groei inkoop elektriciteit $(-0,02)$ (tabel 2.2 ). Door de vermindering van inkoop warmte $(+0,11)$ nam de $\mathrm{CO}_{2}$-emissie niet af maar toe. De factoren verkoop elektriciteit en krimp van het areaal hadden in de periode 20102014 het grootste effect.

Het gezamenlijk effect van deze 5 invloedsfactoren bedroeg -1,28 Mton $\mathrm{CO}_{2}$ en verklaart $69 \%$ van de totale reductie in de periode 2010-2014. Het resterende saldo van -0,57 Mton $\mathrm{CO}_{2}$ was het 
gezamenlijk effect van intensivering, extensivering en energiebesparing, ofwel het effect van de mutatie van het energiegebruik per $m^{2}$. Het totaaleffect van het energiegebruik per $m^{2}$ bracht dus een verlaging van de $\mathrm{CO}_{2}$-emissie met zich mee. Dit betekent dat het totaaleffect van energiebesparing en extensivering groter was dan het effect van intensivering. De daling van de $\mathrm{CO}_{2}$-emissie door de mutaties van het areaal en de energievoorziening werd hierdoor verder vergroot.

Periode 2014-2018

In de periode 2014-2018 daalde de $\mathrm{CO}_{2}$-emissie door krimp van het areaal (-0,24 Mton), toename van duurzame energie (-0,20 Mton) en toename inkoop elektriciteit (-0,11 Mton) (tabel 2.2). Door de stijging van de verkoop van elektriciteit (+0,10 Mton) nam de $\mathrm{CO}_{2}$-emissie niet af maar toe. Door de gelijk gebleven inkoop van warmte van derden had deze factor in deze periode geen effect. De factoren krimp van het areaal en toename duurzame energie hadden in de periode 2014-2018 het grootste effect.

Het gezamenlijk effect van deze eerste 5 invloedsfactoren bedroeg $-0,44 \mathrm{Mton} \mathrm{CO}_{2}$. In de periode 2014-2018 ontstond een saldo van $+0,35$ Mton voor het gezamenlijk effect van intensivering, extensivering en energiebesparing, ofwel het effect van de mutatie van het energiegebruik per $\mathrm{m}^{2}$. In tegenstelling tot de periode 2010-2014 bracht het effect van het energiegebruik per $\mathrm{m}^{2}$ geen verlaging, maar een stijging van de $\mathrm{CO}_{2}$-emissie met zich mee. Dit betekent dat het effect van intensivering groter was dan het gezamenlijke effect van extensivering en energiebesparing.

\subsection{Energiekosten}

De inzet van wkk's is in de energievoorziening van de glastuinbouw een dominante factor. Het gebruik van wkk gaat samen met extra inkoop van aardgas, minder inkoop van elektriciteit, meer verkoop van elektriciteit en grotere beschikbaarheid van rookgas- $\mathrm{CO}_{2}$ (hoofdstuk 4). Voor de glastuinbouw zijn daardoor de netto-energiekosten (inkoop minus verkoop) van belang.

$\mathrm{Na}$ een lichte daling in 2017 zijn de netto-energiekosten $\left(€ / \mathrm{m}^{2}\right)$ in 2018 gestegen tot gemiddeld circa $€ 9,60$ per $\mathrm{m}^{2}$ (figuur 2.5). Zowel de inkoopkosten als de opbrengsten van de verkoop zijn in 2017 en 2018 toegenomen. De toename van de inkoopkosten was in 2018 sterker dan de toename van opbrengsten van de verkoop, waardoor de netto-energiekosten in 2018 toenamen. Zowel in 2017 als in 2018 was de spark spread gunstiger. Hierdoor namen de hoeveelheid elektriciteit, die werd geproduceerd voor de verkoop, en de opbrengsten van de verkoop toe.

Over een langere periode bezien lieten de netto-energiekosten in de periode 2010-2013 een toename zien van gemiddeld bijna $€ 8$ tot ruim $€ 10$ per $\mathrm{m}^{2}$ (figuur 2.5). Dit kwam door toename van de inkoopkosten en een daling van de opbrengsten uit verkoop. Na 2013 namen de netto-kosten weer af tot een niveau van circa $€ 8$ per $\mathrm{m}^{2}$ in 2016. Dit kwam doordat de daling van de kosten voor inkoop een groter effect had vergeleken met de verdere daling van de opbrengsten van de verkoop. In 2018 naderen de netto-energiekosten weer het niveau van 2013.

De kosten voor inkoop bestaan uit de commodityprijs, de dienstenkosten en heffingen. De opbrengsten van de verkoop betreffen alleen commodity's; dienstenkosten en heffingen zijn voor rekening van de afnemer.

De gemiddelde gerealiseerde commodityprijs voor inkoop aardgas en inkoop elektriciteit daalde in de periode 2011 tot en met 2016 en nam in 2017 en 2018 weer toe. De inkoopprijs voor elektriciteit daalde tot en met 2017 en liet in 2018 een toename zien. De gerealiseerde verkoopprijs van elektriciteit liet in 2017 en 2018 een toename zien en was in alle jaren hoger dan de prijs voor inkoop. Dit kwam doordat de verkoop vooral overdag plaatsvond en de inkoop vooral in de avond, nacht en ochtend; dan zijn de prijzen lager. 


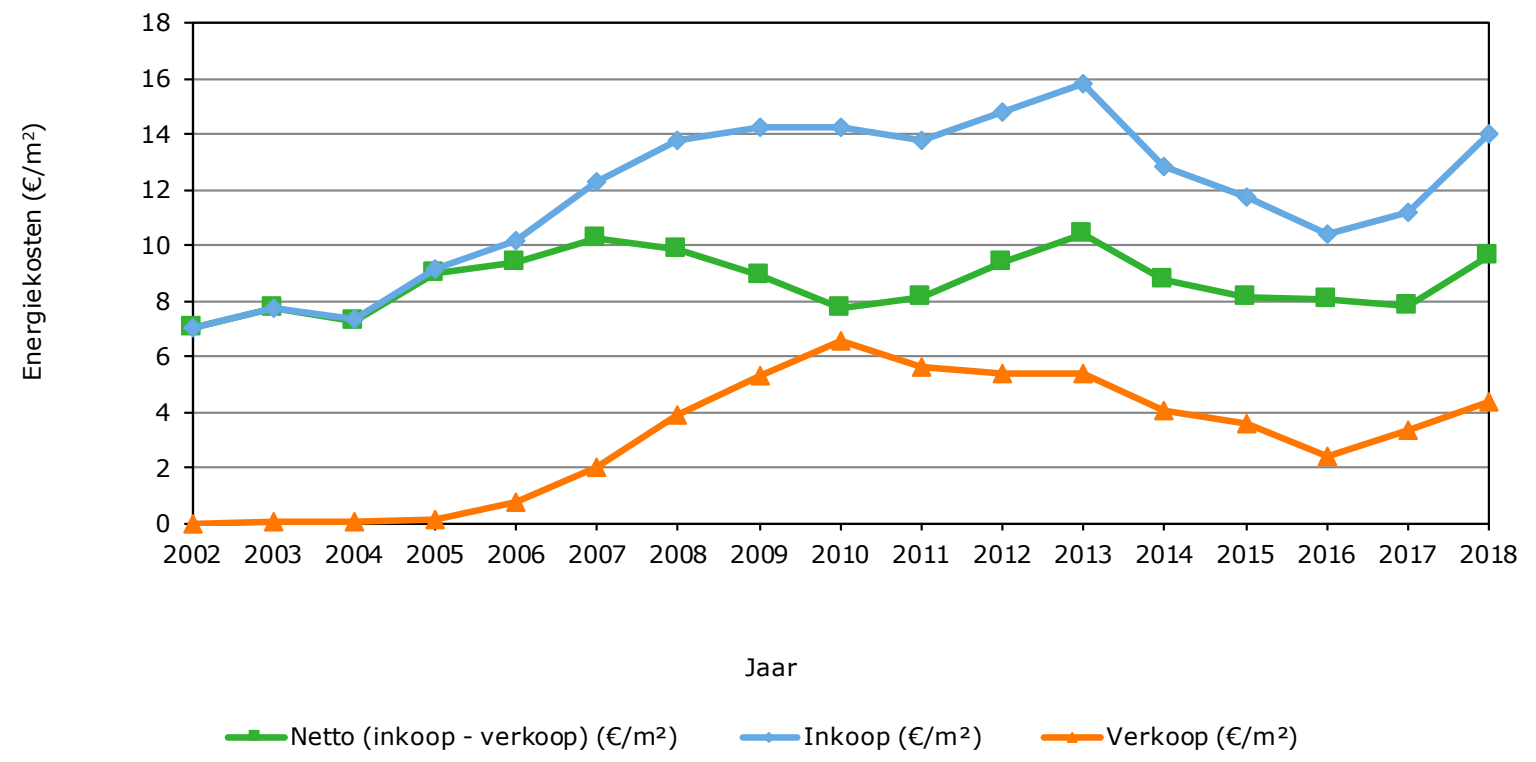

Figuur 2.5 Gemiddelde energiekosten glastuinbouw $\left(€ / m^{2}\right)$ a)

a) Cijfers 2018 voorlopig.

Bron: Bedrijveninformatienet van Wageningen Economic Research.

\subsection{Warmte- en elektriciteitsgebruik}

\section{Totaal energiegebruik}

Het totale energiegebruik van de glastuinbouw daalde in de periode 2010-2014 van 127,1 naar $96,0 \mathrm{PJ}(-25 \%)$ (bijlage 1). Daarna nam het toe tot 101,1 PJ in 2017 (+5\%) om in 2018 weer af te nemen tot $100,5 \mathrm{PJ}$. Deze ontwikkeling ging samen met een toenemende energievraag door intensivering, vermindering van de energievraag door extensivering en energiebesparing, daling van de omvang van de sector (ha) en verschillen in buitentemperatuur tussen de jaren (paragraaf 2.5). $\mathrm{Na}$ temperatuurcorrectie daalde het totale energiegebruik in de periode 2010-2014 van 122,0 tot $101,4 \mathrm{PJ}(-17 \%)$ en nam toe tot 103,1 PJ in de periode 2014-2017. Het jaar 2018 liet een beperkte afname zien. In 2018 lag het totale energiegebruik na temperatuurcorrectie ruim 1\% hoger dan in 2014.

De energievraag wordt in beginsel niet beïnvloed door de energievoorziening of de herkomst van de energie (fossiel of duurzaam) ${ }^{3}$. Door uit te gaan van het energiegebruik per $\mathrm{m}^{2}$ na correctie voor buitentemperatuur, hebben veranderingen in areaal en verschillen in buitentemperatuur geen invloed en resteert de invloed van intensivering, extensivering en energiebesparing.

\section{Energiegebruik per $\mathrm{m}^{2}$}

Uit figuur 2.6 blijkt dat het gemiddelde energiegebruik per $\mathrm{m}^{2}$ na correctie voor de buitentemperatuur over de periode 2000-2014 daalde (-10\%) en in de periode 2014-2018 weer toenam (+7\%). In 2018 bedroeg het totaal energiegebruik per $\mathrm{m}^{2}$ na temperatuurcorrectie $1,14 \mathrm{GJ}$ per $\mathrm{m}^{2}$. Dit is ongeveer gelijk aan het niveau in de periode 2006-2008.

\section{Warmte en elektriciteit}

Het energiegebruik per $\mathrm{m}^{2}$ na correctie voor de buitentemperatuur is in figuur 2.6 vanaf 2006 opgesplitst in warmte en elektriciteit. Uit de figuur blijkt dat de toename van het totaal energiegebruik per $\mathrm{m}^{2}$ kas vanaf $2014(+7 \%)$ samengaat met zowel groei van het warmtegebruik als van groei van de elektriciteitsconsumptie. Daarbij was de groei van de elektriciteitsconsumptie (+22\%) groter dan van de warmteconsumptie $(+3 \%)$. In de periode 2006-2010 nam het totaal energiegebruik per $\mathrm{m}^{2}$ na temperatuurcorrectie ook toe, maar deze toename zat bij de warmte.

\footnotetext{
3 De $\mathrm{CO}_{2}$-voorziening met rookgassen uit aardgas in perioden zonder warmtevraag (zomerstook) is hierop een uitzondering
} 
Over de periode 2010-2018 nam de warmteconsumptie per $\mathrm{m}^{2}$ met $18 \%$ af en de elektriciteitsconsumptie met $129 \%$ toe. In 2018 bestond circa $77 \%$ van het totale energiegebruik uit warmte en circa $23 \%$ uit elektriciteit. In 2010 was dit $90 \%$ en $10 \%$. Er is dus een verschuiving aan de gang van warmte naar elektriciteitsvraag.

De groei van de elektriciteitsconsumptie per $\mathrm{m}^{2}$ (vanaf 2010) komt hoofdzakelijk door intensivering in de vorm van groeilicht. Er werd meer areaal belicht en de intensiteit $\left(\mathrm{W}_{\mathrm{e}} / \mathrm{m}^{2}\right)$ nam toe. Daarnaast doen het gebruik van duurzame energiebronnen, mechanisatie, automatisering en verdere optimalisatie van het kasklimaat de elektriciteitsconsumptie toenemen (Van der Velden en Smit, 2013).

De warmteconsumptie per $\mathrm{m}^{2}$ neemt vanaf 2014 weer iets toe. Dit is het totaaleffect van intensivering, extensivering en energiebesparing. Hieruit kan worden afgeleid dat het totaaleffect van intensivering op de warmtevraag in deze periode groter is dan het effect van extensivering plus energiebesparing. Dit effect is bij warmte echter minder groot dan bij elektriciteit.

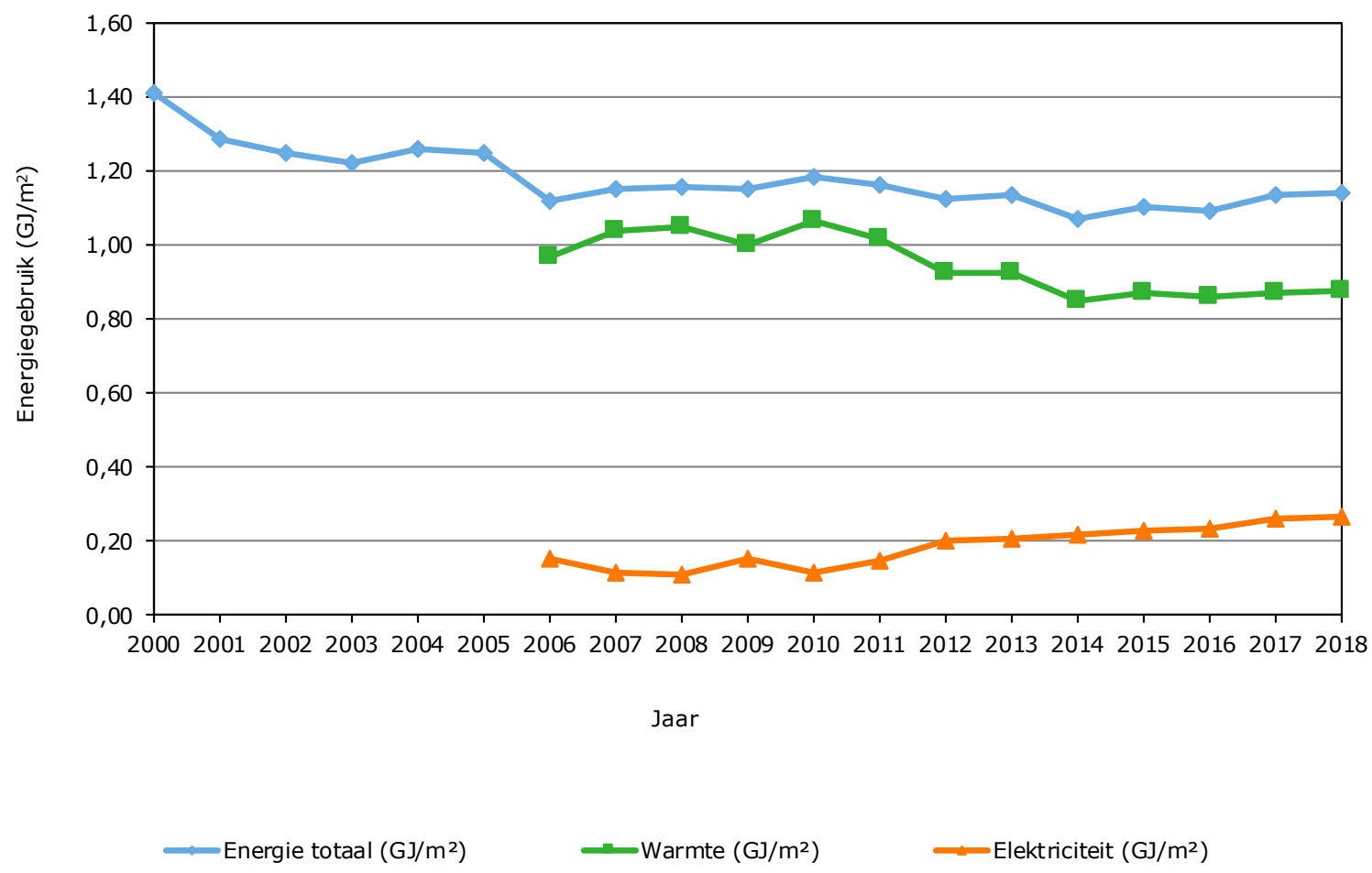

Figuur 2.6 Energiegebruik per $\mathrm{m}^{2}$ gecorrigeerd voor de buitentemperatuur a) a) Cijfers 2018 voorlopig.

\subsection{Energievoorziening zonder $\mathrm{CO}_{2}$-emissie}

In de paragrafen 2.2 en 2.5 is de ontwikkeling van de $\mathrm{CO}_{2}$-emissie beschreven. In deze paragraaf wordt de ontwikkeling van de energievoorziening zonder $\mathrm{CO}_{2}$-emissie (c.q. zonder direct aardgasverbruik) van de glastuinbouw behandeld. Op basis van de IPCC-methode betreffen dit:

- gebruik duurzame energie (productie en inkoop),

- inkoop elektriciteit (niet duurzaam) en

- inkoop warmte (niet duurzaam).

In figuur 2.7 zijn de aandelen van deze drie in het totale energiegebruik vanaf 2010 weergegeven. In dit totale energiegebruik is de verkoop van energie en dus ook de verkoop vanuit de wkk's op aardgas in mindering gebracht. In de figuur is zichtbaar dat het aandeel duurzame energie is gegroeid van 
nagenoeg nihil in 2000 tot 7,3\% in 2018. Het aandeel inkoop warmte (niet duurzaam) van buiten de sector nam af van $11 \%$ in 2000 tot ruim 3\% in 2018. Na 2010 is deze daling beperkt en na 2014 is het aandeel inkoop warmte min of meer stabiel. De inkoop van elektriciteit (niet duurzaam) vertoond een grilliger verloop. Over de hele periode vanaf 2010 is er een duidelijke toename van 4 tot $9 \%$. Het jaar 2017 is hierop een uitzondering. Dit komt door de grotere inkoop duurzame elektriciteit in dat jaar en die telt mee in het aandeel duurzame energie en niet bij inkoop elektriciteit.

In figuur 2.7 is ook de ontwikkeling van het totale aandeel van de energievoorziening zonder $\mathrm{CO}_{2}$ emissie vanaf 2000 zichtbaar gemaakt. De periode 2000-2004 vertoont een afname, vooral door daling van de inkoop van warmte van derden. Deze periode werd gevolgd door een groei van de energievoorziening zonder $\mathrm{CO}_{2}$-emissie in de jaren 2005 en 2006. In deze jaren steeg het aandeel duurzaam en inkoop elektriciteit en stabiliseerde de inkoop van warmte van derden, terwijl de totale energieconsumptie daalde. De periode 2006-2010 toont wederom een daling. Dit kwam vooral door de opkomst van wkk, verdere daling van de inkoop warmte van derden en daling van de inkoop elektriciteit.

Vanaf 2010 is er een duidelijke toename van het aandeel energievoorziening zonder $\mathrm{CO}_{2}$-emissie. In 2010 bedroeg het totale aandeel bijna $12 \%$ en in 2018 is dit toegenomen tot ruim 19\%. Dit is een toename van meer dan twee derde in 8 jaar. De toename komt vooral door de groei van duurzame energie. Daarnaast heeft ook de groei van de inkoop van elektriciteit een positieve invloed. Het aandeel inkoop warmte bleef vrijwel stabiel. Het voorgaande betekent dat de glastuinbouw in 2018 voor haar energievoorziening nog grotendeels ( $81 \%$ ) afhankelijk is van het directe verbruik van aardgas. Het betekent ook dat de glastuinbouw vanaf 2010 stappen heeft gezet om minder afhankelijk te worden van het directe verbruik van aardgas.

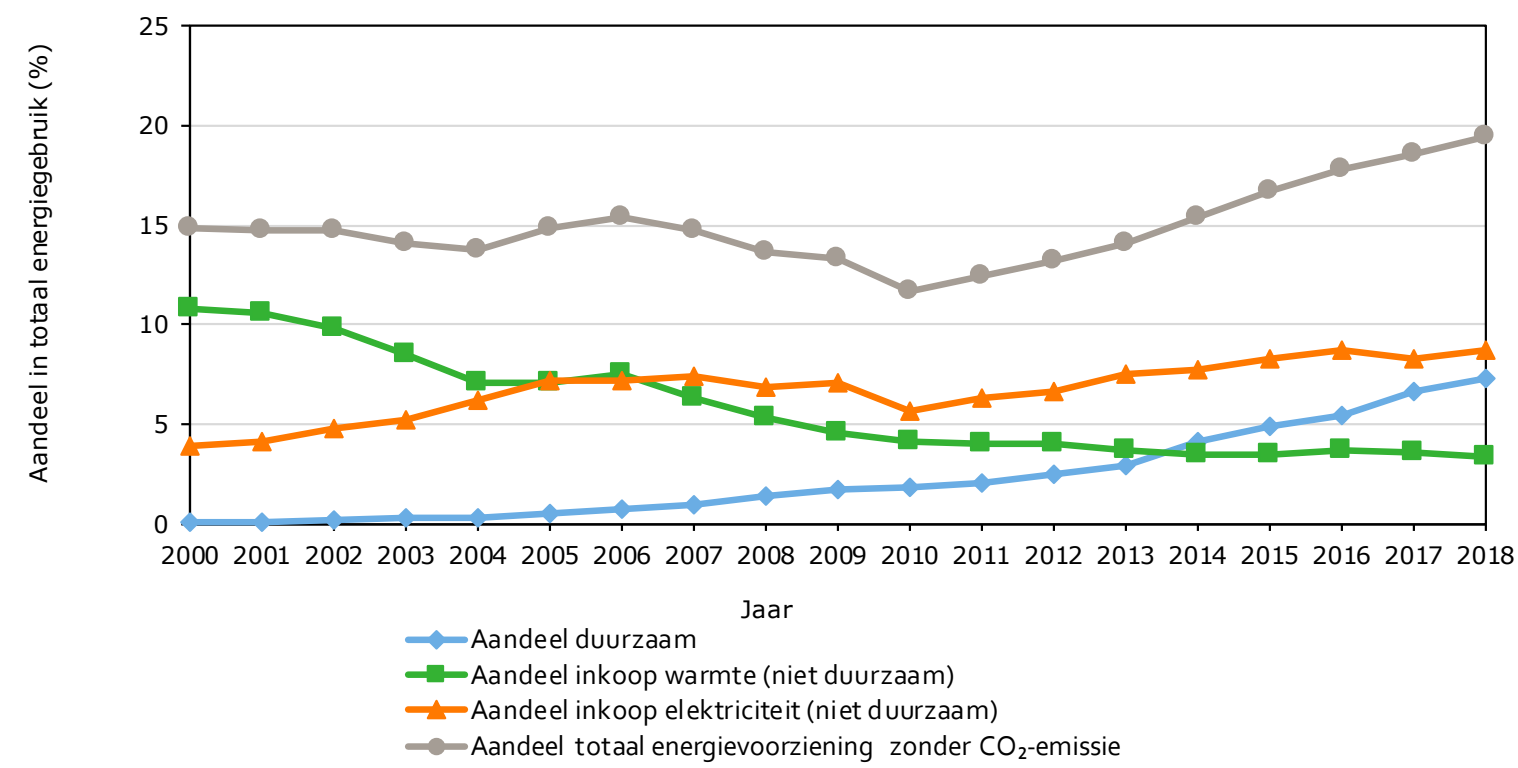

Figuur 2.7 Aandeel energievoorziening zonder $\mathrm{CO}_{2}$-emissie in totaal energiegebruik a) a) Cijfers 2018 voorlopig. 


\section{Nadere analyse duurzame energie}

\section{$3.1 \quad$ Inleiding}

In de volgende paragrafen komen achtereenvolgens de toepassing en de ontwikkeling van de afzonderlijke duurzame energiebronnen, de bedrijfsstructuur, de $\mathrm{CO}_{2}$-emissiereductie en de inkoop van externe $\mathrm{CO}_{2}$ aan de orde. Externe $\mathrm{CO}_{2}$ is geen duurzame energie, maar is nodig om grootschalig gebruik van duurzame warmte en inkoop van warmte door de glastuinbouw mogelijk te maken. Aan het einde van dit hoofdstuk wordt de ontwikkeling van de inkoop van externe $\mathrm{CO}_{2}$ behandeld.

\subsection{Bronnen van duurzame energie}

\subsubsection{Toepassing}

De Nederlandse glastuinbouw paste in 2018 zes bronnen van duurzame energie toe. Aardwarmte was met $48 \%$ de voornaamste bron (tabel 3.1 en figuur 3.2). Daarna volgden inkoop duurzame elektriciteit (20\%), zonne-energie (11\%), biobrandstoffen (10\%), inkoop duurzame warmte (10\%) en inkoop duurzaam gas $(<1 \%)$ (tabel 3.1$)$.

Tabel 3.1 Toepassing van duurzame energievormen in de Nederlandse glastuinbouw in 2018 v)

\begin{tabular}{|c|c|c|c|c|c|c|c|}
\hline \multirow[t]{2}{*}{ Duurzame energievorm } & Bedrijven a) & Areaal a) & Gemiddeld & Warmte & Elektriciteit & Totaal & Aandeel \\
\hline & aantal & ha & ha per bedrijf & PJ & TWh & PJ & $\%$ \\
\hline Aardwarmte b) & 81 & 741 & 9,1 & 3,6 & - & 3,6 & 48 \\
\hline - warmte & 35 & 150 & 4,3 & 0,5 & - & 0,5 & \\
\hline - warmte en elektriciteit & 6 & 45 & 7,4 & 0,2 & $<0,01$ & 0,2 & \\
\hline - elektriciteit & 62 & 257 & 4,1 & - & 0,01 & 0,0 & \\
\hline - warmte & 62 & 214 & 3,4 & 0,8 & - & 0,8 & \\
\hline Inkoop duurzaam: & - d) & - d) & $-c)$ & 1,5 & 0,40 & 3,0 & \\
\hline - elektriciteit c) & $-d)$ & $-d)$ & - c) & - & 0,40 & 1,4 & 20 \\
\hline . warmte decentraal & 9 & 68 & 7,6 & 0,6 & - & 0,6 & \\
\hline Totaal e) & 255 & 1.474 & 5,8 & 5,9 & 0,42 & 7,4 & 100 \\
\hline
\end{tabular}

v) Cijfers voorlopig.

a) Peildatum eind 2018.

b) Cijfers aardwarmte afkomstig van Dutch Association of Geothermal Operators (DAGO).

c) Duurzame energie van buiten de sector.

d) Cijfers niet bekend.

e) Als meerdere vormen van duurzame energie op een bedrijf worden toegepast is dat eenmaal meegenomen in het totaal.

Het totale gebruik van duurzame energie groeide in 2018. Deze groei was het saldo van nieuwe projecten, aanpassing van bestaande projecten, projectbeëindiging en verandering van de inkoop. De groei zat in 2018 bij aardwarmte en inkoop van duurzame warmte (figuur 3.1). De inkoop van duurzame elektriciteit liet een afname zien. Het totaal van inkoop van duurzame elektriciteit en duurzame warmte bleef in 2018 per saldo vrijwel gelijk. De achtergronden van deze ontwikkelingen komen aan bod in paragraaf 3.2.2. In 2018 steeg zowel het absolute als het relatieve gebruik van 
duurzame energie minder hard dan in 2017. Dit kwam door de daling van inkoop van duurzame elektriciteit en productieonderbrekingen bij geothermie.

Totaal werd er in 2018 door de glastuinbouw 7,4 PJ duurzame energie gebruikt. Het gebruik van duurzame energie is hiermee in 3 jaar met de helft toegenomen (figuur 2.4). De toegepaste duurzame energie bestond voor $80 \%$ uit warmte en voor $20 \%$ uit elektriciteit (tabel 3.1). De duurzame warmte wordt al jaren vooral door de sector zelf geproduceerd (in 2018 87\%) en de elektriciteit wordt vooral buiten de sector ingekocht (in 2018 96\%).

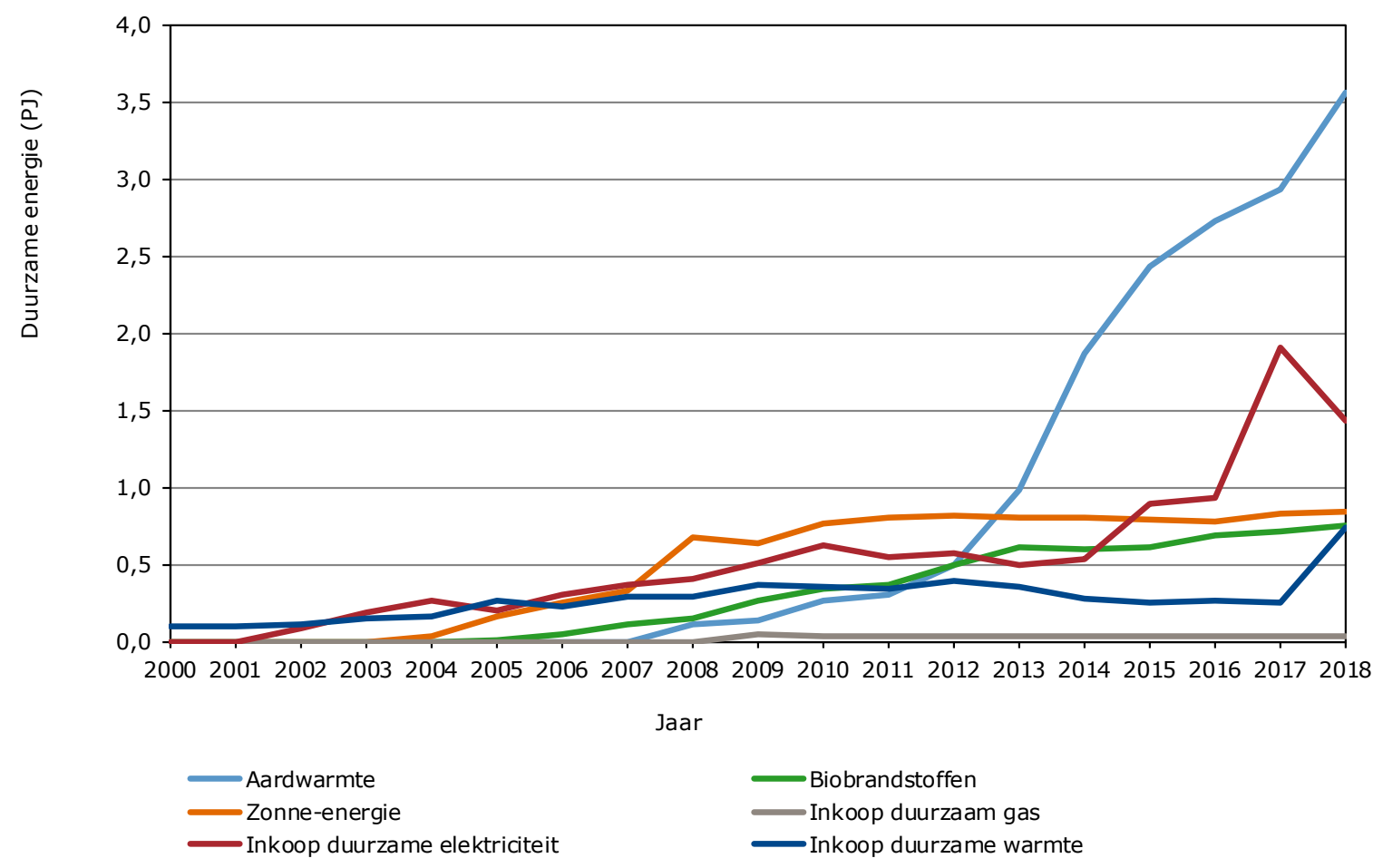

Figuur 3.1 Ontwikkeling van het gebruik duurzame energie in de glastuinbouw per bron per jaar v) v) Cijfers 2018 voorlopig.

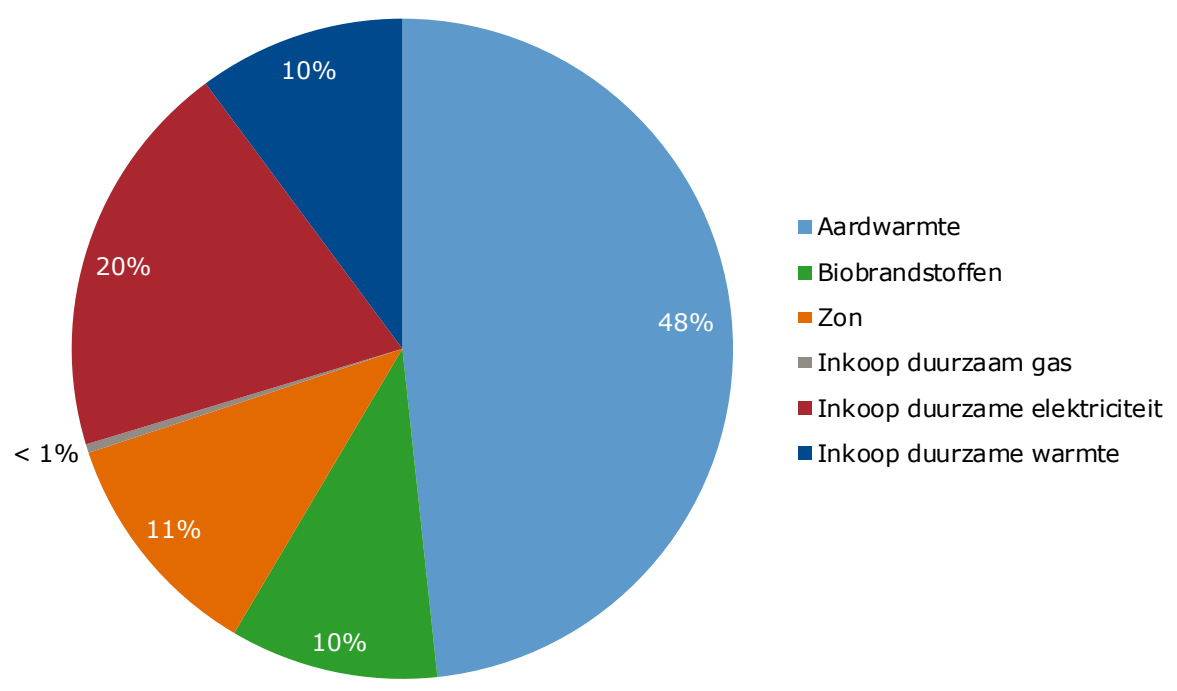

Figuur 3.2 Aandeel gebruik van duurzame energie in de glastuinbouw in 2018 per bron v) v) Cijfers voorlopig. 


\subsubsection{Ontwikkeling per bron}

\section{Aardwarmte}

Het aantal glastuinbouwbedrijven met aardwarmte nam in 2018 toe tot 81 . Hiervan waren er 61 risicodragend deelnemer (exploitant) en 20 afnemer. Het areaal glastuinbouw met aardwarmte groeide van 621 naar 741 ha. Er werd in 2018 op ruim 8\% van het totaal areaal glastuinbouw in Nederland aardwarmte toegepast. Op $80 \%$ van dit areaal werd groente geteeld. Dit hangt vooral samen met de warmtevraag en de schaalgrootte van deze bedrijven.

Van het totaal areaal met aardwarmte wordt op 93\% aardwarmte gebruikt die door deze glastuinbouwbedrijven zelf is gewonnen. Op 7\% van het areaal met aardwarmte wordt deze ingekocht van andere glastuinbouwbedrijven. Eind 2018 waren er in de glastuinbouw 17 aardwarmtedoubletten gerealiseerd. In 2018 waren niet alle projecten het volledige jaar of met het ontwerpvermogen in bedrijf. Dit kwam doordat twee nieuwe projecten in de loop van het jaar werden opgestart en bestaande projecten te maken hadden met onderhoud, storingen en andere onderbrekingen. Desondanks was de gemiddelde inzet van aardwarmte per $\mathrm{m}^{2}$ kas met 0,5 G] (15 $\mathrm{m}^{3}$ a.e.) in 2018 stabiel ten opzichte van 2017.

De totale hoeveelheid toegepaste aardwarmte nam in 2018 toe met bijna $22 \%$. De groei kwam door nieuwe projecten en verbetering van de benutting bij bestaande projecten. De verbetering van de benutting kwam door uitbreiding van het aangesloten areaal en verbetering van de uitkoeling door inzet van opgedane expertise, regeltechniek en cascadeschakelingen van de verwarmingsinstallaties.

\section{Zonne-energie}

De toepassing van herwonnen zonnewarmte was in 2018 stabiel, desondanks blijft het de duurzame energievorm met de meeste projecten. Enerzijds kon er door meer instraling en hoge temperaturen in de lente en de zomer meer warmte gewonnen worden, anderzijds was er door diezelfde instraling en warmte minder warmtevraag om de herwonnen warmte toe te passen.

In totaal werd zonnewarmte toegepast door 62 bedrijven met een gezamenlijk glasareaal van 214 ha. Herwinning zonnewarmte ontwikkelt zich al jaren alleen nog bij bedrijven waarbij koude nodig is voor koeling van de teelt. De zonnewarmte werd vooral toegepast bij plantenbedrijven (131 ha), op afstand gevolgd door bloemen (47 ha) en groente (36 ha). Bij bloemen waren alle bedrijven met herwinning van zonnewarmte uit grondkoeling te vinden, hoofdzakelijk bij de gewassen alstroemeria, amaryllis en freesia. Bij planten betreft het hoofdzakelijk de teelt van phalaenopsis. Op meer dan de helft van het totale areaal van deze vier gewassen wordt koeling gecombineerd met herwinning van zonnewarmte.

In 2018 groeide het aantal bedrijven met winning van elektriciteit via fotovoltaïsche cellen (zon PV) verder door. Bij productie van duurzame elektriciteit door de glastuinbouw is zonne-elektriciteit sinds 2017 de voornaamste bron. De gewonnen elektriciteit werd voor circa driekwart toegepast op de bedrijven en de rest werd verkocht. Zonne-elektriciteit groeit vooral doordat bedrijven gebruikmaken van stimuleringsregelingen. Het aandeel van zon-elektrische energie in de totale hoeveelheid toegepaste, duurzame elektriciteit blijft echter zeer beperkt (3\%).

\section{Biobrandstof}

Het aantal glastuinbouwbedrijven waar in 2018 biobrandstof werd toegepast, steeg naar 40 en het areaal naar 194 ha. Er waren zes bedrijven met een gezamenlijk areaal van 45 ha waar biobrandstof gebruikt werd in een wkk. De inzet van biobrandstof voor de productie van alleen warmte met ketels vond plaats bij 35 bedrijven, met een gezamenlijk areaal van 150 ha. Van het areaal met biobrandstof in ketels was 68 ha te vinden bij de groenten, 58 ha bij de planten en 21 ha bij de bloemen. Hout is al jaren de voornaamste biobrandstof voor de glastuinbouw. Van de 41 projecten gebruikten er in 2017 38 resthout uit industrie of snoeihout uit groenbeheer. Drie bedrijven haalden hun biobrandstof uit vergisting en zetten deze met een bio-wkk om naar warmte en elektriciteit.

In 2018 namen 38 bedrijven deel aan de exploitatie van een installatie op biobrandstof. Hiernaast werd bij drie glastuinbouwbedrijven door deze exploitanten warmte geleverd. De combinatie van een onzekere en relatief hoge biobrandstofprijs en een relatief lage aardgasprijs leidt vooral bij bestaande 
projecten steeds vaker tot stevige bedrijfseconomische afweging tussen deze twee brandstofsoorten. Per saldo steeg de toepassing van energie uit biobrandstoffen in 2018 met $4 \%$.

Gedurende 2018 waren meerdere partijen binnen en buiten de glastuinbouw actief met de realisatie van nieuwe (en relatief grote; $>5 \mathrm{MW}_{\mathrm{th}}$ ) installaties voor inzet in de glastuinbouw. Deze initiatieven beogen na 2018 installaties in bedrijf te nemen en maken nog geen deel uit van het gebruik in 2018.

\section{Inkoop}

Door de glastuinbouw wordt duurzame elektriciteit, duurzame warmte en duurzaam gas ingekocht. De duurzaamheid van ingekochte duurzame elektriciteit en duurzaam gas uit openbare netten wordt met Garanties van Oorsprong (GVO) gewaarborgd.

Glastuinbouwbedrijven kopen duurzame elektriciteit in vanuit eigen motieven of vanuit deelname aan de regelingen en keurmerken waarbij een mate van duurzaamheid een vereiste is. De inkoop van duurzame elektriciteit liet in 2018 een daling zien. Er werd 400 miljoen kWh ingekocht. Hiermee is de sterke stijging van 2017 niet helemaal teniet gedaan. De extra kosten van inkoop duurzame elektriciteit ten opzichte van gangbare elektriciteit waren in 2018 beperkt, maar hoger dan in 2017. Mede hierdoor waren energieleveranciers minder actief om duurzame elektriciteit aan tuinders en collectieven te verkopen. Hieruit blijkt dat duurzame elektriciteit voor een deel wordt aangekocht vanuit prijsafweging.

Inkoop van duurzame warmte vindt plaats vanuit centrale en decentrale projecten. Bij centrale inkoop betreft het een deel van de restwarmte dat duurzaam wordt opgewekt met bijstook van biobrandstof in centrales. Bij decentrale projecten wordt op kleinere schaal lokaal duurzame warmte uit biobrandstoffen geleverd aan glastuinbouwbedrijven door exploitanten van installaties van buiten de sector. De inkoop van duurzame warmte verdrievoudigde in 2018 bijna naar 0,7 PJ. Dit kwam enerzijds door de ingebruikname van relatief grote, decentrale installaties in de directe nabijheid van glastuinbouwbedrijven en anderzijds door een sterke verhoging van de duurzame fractie bij centrale warmtelevering.

Duurzaam gas betreft biogas dat is geproduceerd en geconverteerd naar een standaardkwaliteit, waardoor dit gas via het aardgasnet geleverd wordt aan de eindverbruiker. De aankoopmotieven voor de inkoop van duurzaam gas zijn globaal gelijk aan die voor de inkoop van duurzame elektriciteit. De kosten voor de inkoop van duurzaam gas zijn in vergelijking met duurzame elektriciteit hoog, hierdoor bleef in 2018 net als eerdere jaren het gebruik ervan zeer beperkt.

\section{Ontwikkelingen}

Er waren in 2018 twee ontwikkelingen die het gebruik van duurzame energie sterk beïnvloedden. De eerste ontwikkeling had betrekking op aardwarmte. De productie en het aandeel van aardwarmte, het aantal projecten en het areaal dat aardwarmte toepaste, groeide in 2018. Om aardwarmtebronnen maximaal te benutten zijn de bedrijven actief om de uitkoeling in de aangesloten verwarmingssystemen te verbeteren en werd het areaal, aangesloten op de bronnen, vergroot. Hiernaast zijn er in 2018 twee nieuwe aardwarmteprojecten gestart en twee projecten uit 2017 volledig in productie gekomen. Enkele bestaande aardwarmteprojecten hebben te maken gehad met productieonderbrekingen en -beperkingen door onder andere onderhoud, onderzoek en modificaties. Door inspanningen van de betrokkenen is het aannemelijk dat deze projecten weer in bedrijf komen. Samen met nieuwe aardwarmteprojecten die in voorbereiding of realisatie zijn, kan aardwarmte als belangrijkste duurzame energiebron voor de glastuinbouw blijven doorgroeien.

De tweede belangrijke ontwikkeling zat bij de inkoop van duurzame energie van derden. Hier heeft een verschuiving plaatsgevonden. In 2018 nam de ingekochte hoeveelheid duurzame elektriciteit duidelijk af. De inkoop van duurzame warmte geleverd door partijen buiten de sector nam echter aanzienlijk toe. De daling van de inkoop van duurzame elektriciteit was grotendeels het gevolg van een hogere prijs ten opzichte van niet-duurzame inkoop in 2018. Hiermee bleek de stijging in 2017 voor een groot deel niet structureel van aard. De groei van de inkoop duurzame warmte bij centrale en decentrale projecten lijkt, gezien de investeringen binnen en buiten de tuinbouw alsook meerjarige leverings-/afnameovereenkomsten, wel structureel voor in ieder geval de middellange termijn. 
De realisatie en optimalisatie van geothermie en de inzet van warmte van derden zijn voorbeelden waarbij glastuinbouwbedrijven onderling - en steeds meer met hun partners - buiten de sector samenwerken. Door samen te realiseren, kennis te vergaren en risico's te delen blijken nieuwe en soms complexe projecten tot stand te kunnen komen en kan de inzet van duurzame energie en het aandeel in de totale energiemix doorgroeien. Door deze samenwerking kunnen duurzame energiebronnen maximaal benut worden en groeit het areaal dat duurzame energie toepast.

Een andere noemenswaardige ontwikkeling is de groei van de inzet van zon-elektrische energie, opgewekt en toegepast door de glastuinbouw zelf. Weliswaar is de hoeveelheid nog beperkt, maar het is inmiddels de grootste bron van zelf geproduceerde duurzame elektriciteit. De groei kwam doordat het investeringsrendement van zonnepanelen toeneemt en doordat stimuleringsmaatregelen risico's beperken. Hiernaast was 2018 ook een uitzonderlijk goed jaar voor wat betreft zoninstraling.

\subsubsection{Productie, inkoop, verkoop en consumptie}

De productie, inkoop, verkoop en consumptie van duurzame energie in 2018 is samengevat in figuur 3.3. Deze balans laat zien dat de consumptie van duurzame energie voor circa twee derde gedekt werd door eigen productie en voor een derde werd ingekocht bij partijen buiten de sector. Van de door de glastuinbouw zelf geproduceerde, duurzame energie $(5,4 \mathrm{PJ})$ werd een klein deel $(6 \%)$ verkocht. Dit betrof vooral aardwarmte en levering binnen de sector. De inkoop van duurzame energie van collega-tuinders nam in 2018 iets toe door groei van de verkoop van aardwarmte. De inkoop van duurzame energie van buiten de sector nam per saldo iets af. De groei bij inkoop van duurzame warmte kon de daling van de inkoop duurzame elektriciteit net niet compenseren. Per saldo steeg het aandeel van consumptie uit de eigen productie van de sector in 2018 met 3 procentpunten ten opzichte van 2017 (figuur 3.4).

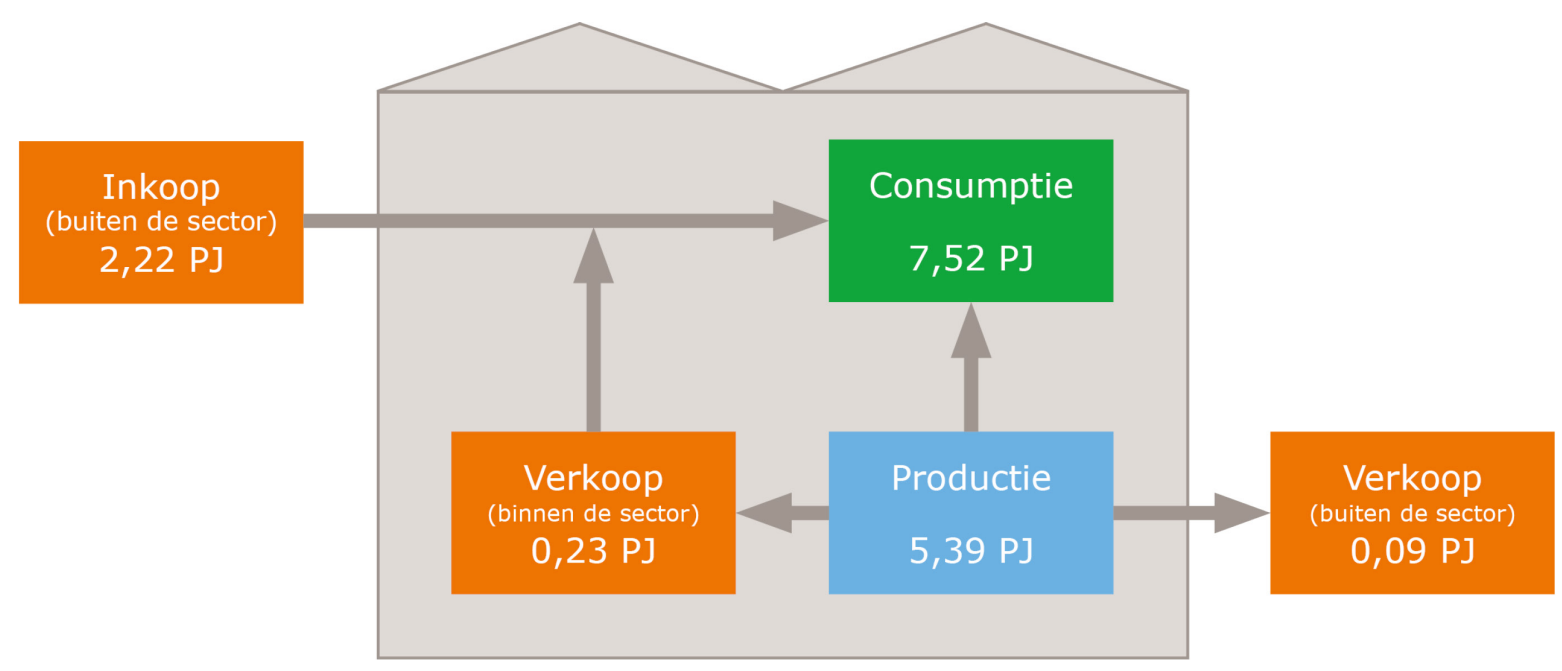

Figuur 3.3 Balans voor duurzame energie van de Nederlandse glastuinbouw in 2018 v) v) Cijfers voorlopig. 


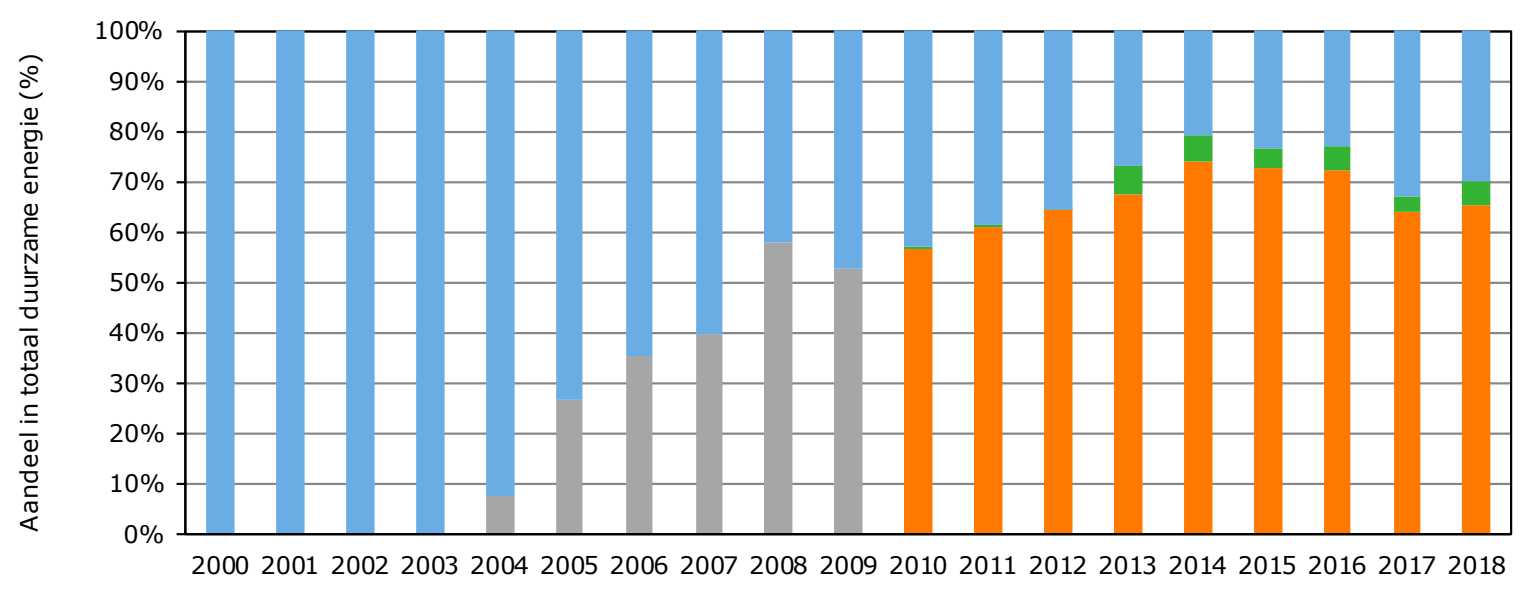

Jaar

- Inkoop door de glastuinbouwsector

घ Productie binnen de glastuinbouwsector (tot 2010)

- Productie binnen de glastuinbouwsector: Afnemers (vanaf 2010)

- Productie binnen de glastuinbouwsector: Exploitanten (vanaf 2010)

Figuur 3.4 Verdeling van de toepassing van duurzame energie naar herkomst per jaar (\%) a), v) a) Vanaf 2010 is toepassing van door de sector geproduceerde duurzame energie gesplitst naar exploitanten en afnemers.

v) Cijfers 2018 voorlopig.

\subsubsection{Bedrijfsstructur}

\section{Bedrijven en areaal}

Het aantal bedrijven met gebruik van duurzame energie (exclusief inkoop uit openbare netten) groeide in 2018 met $18 \%$ naar 255 (figuur 3.6). Deze groei was het saldo van de start van nieuwe projecten, continuering van bestaande projecten en projecten die werden beëindigd. Het areaal met duurzame energie groeide in 2018 met $20 \%$ naar 1.474 ha. Dit was ruim $16 \%$ van totale areaal glastuinbouw in Nederland. De groei van het areaal en het aantal bedrijven komt vooral doordat meer bedrijven zijn aangesloten op aardwarmteprojecten. Ook was er groei bij decentrale duurzame warmte-inkoop en zijn er nieuwe projecten waar zonne-elektriciteit wordt ingezet. In 2018 was de gemiddelde omvang van een glastuinbouwbedrijf met duurzame energie 5,8 ha; dit is ruim twee keer de gemiddelde bedrijfsomvang in de sector (figuur 3.5). Dit komt omdat nieuwe duurzame energieprojecten de laatste jaren vooral bij (clusters van) grote en zeer grote bedrijven werden gerealiseerd. 


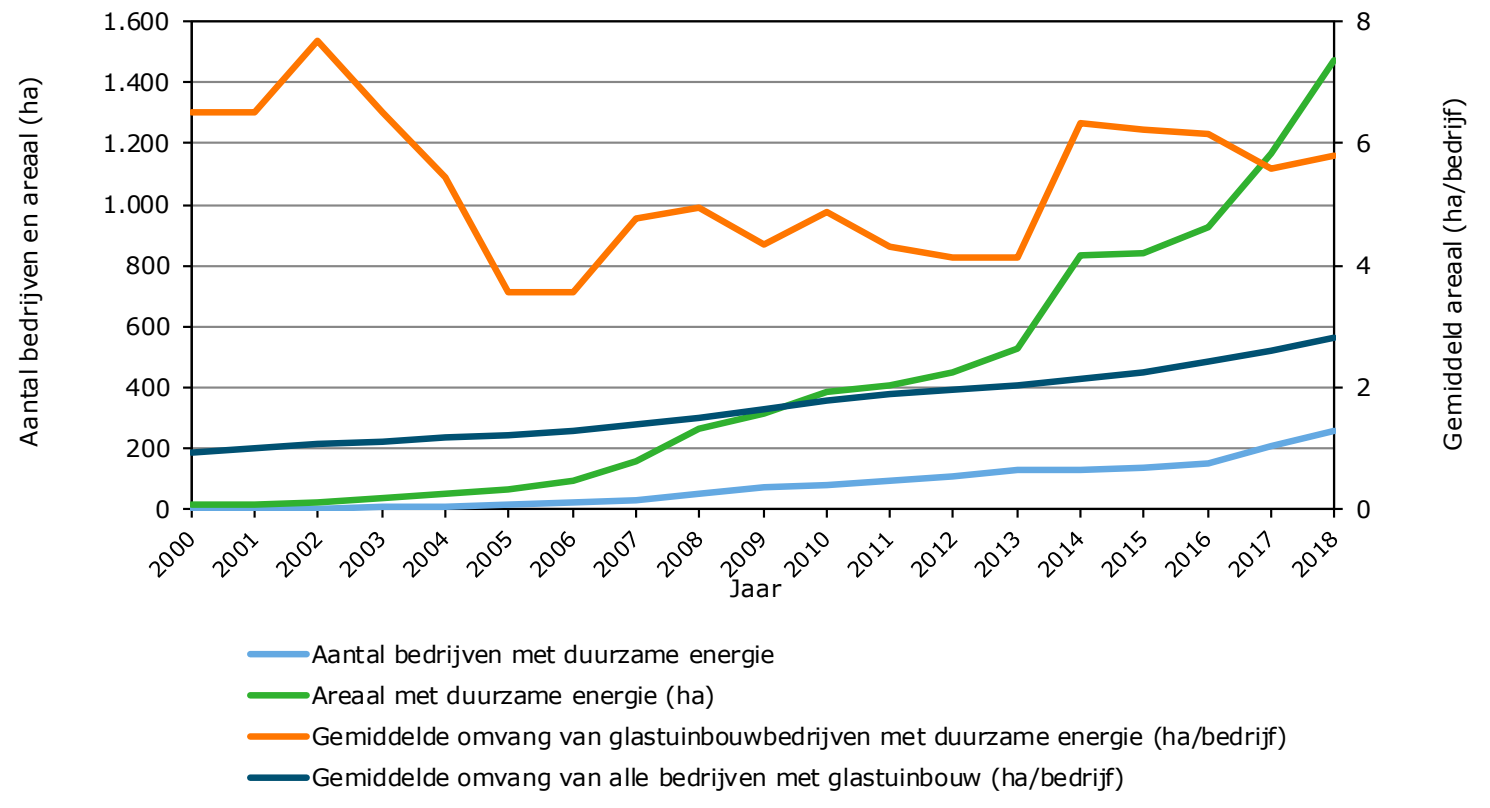

Figuur 3.5 Ontwikkeling van het aantal bedrijven, het areaal en de gemiddelde bedrijfsomvang met duurzame energie en de gemiddelde omvang van alle bedrijven met glastuinbouw a), v)

a) Exclusief inkoop uit openbare netten.

v) Cijfers 2018 voorlopig.

\section{Subsectoren}

In elk van de vier subsectoren in de glastuinbouw wordt duurzame energie toegepast (figuur 3.6). De meeste duurzame energie werd in 2018 toegepast op het groenteareaal en het minst bij

uitgangsmateriaal. Deze twee subsectoren zijn qua areaal in Nederland ook de grootste en de kleinste. Bloemen en planten zitten hier tussenin. Ook in 2018 werd op het areaal bloemen zowel absoluut of relatief minder duurzame energie toegepast dan op het areaal planten. Bij de bloemen wordt gemiddeld minder warmte en meer groeilicht toegepast. In de vraag naar elektriciteit wordt voor een belangrijk deel voorzien met wkk, waardoor het complexer is om duurzame warmte in te passen. Bij groentebedrijven wordt meer $\mathrm{CO}_{2}$-gedoseerd met wkk en ook dit concurreert met duurzame warmte. Door de toename van groeilicht in deze subsector wordt ook hier de inzet van duurzame warmte complexer. Potplantenbedrijven hanteren een relatief hoge kastemperatuur, belichten minder intensief en doseren minder $\mathrm{CO}_{2}$. Hierdoor ondervindt duurzame energie op plantenbedrijven minder concurrentie van aardgasgestookte ketels en wkk. De verdeling van areaal met duurzame energie over de subsectoren (figuur 3.6) vertoont de laatste jaren weinig verandering.

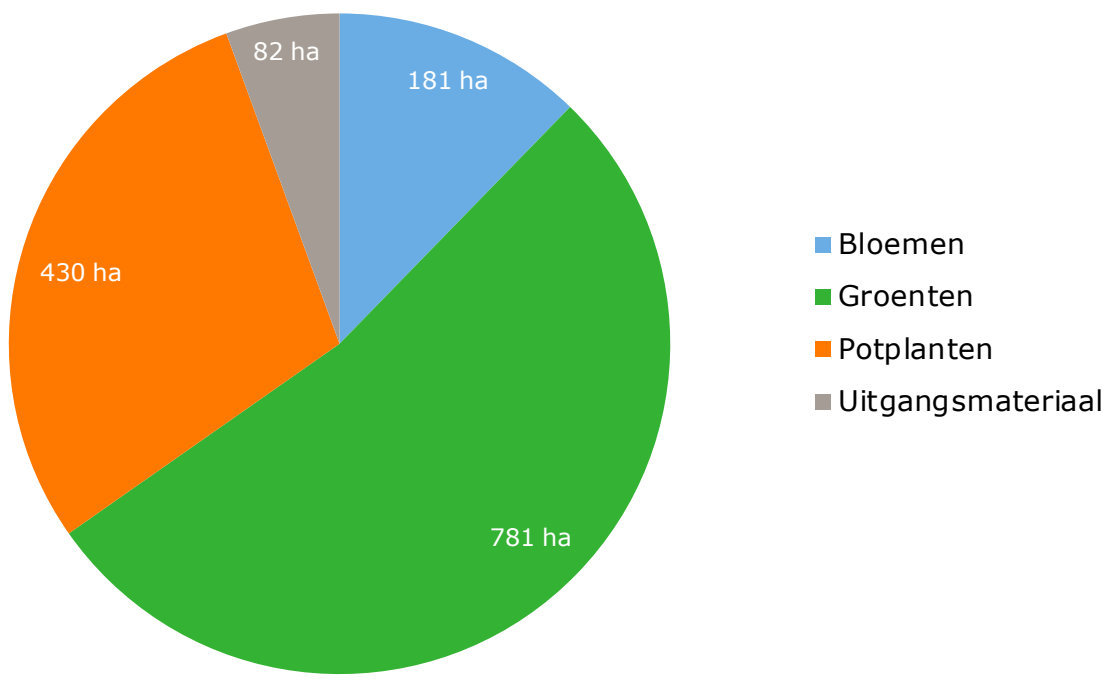

Figuur 3.6 Verdeling van het areaal met duurzame energietoepassing per subsector in 2018 (ha) a), v) a) Exclusief inkoop uit openbare netten.

v) Cijfer voorlopig. 


\section{Bedrijfsomvang}

Het grootste deel van de toepassing van duurzame energie door glastuinbouwbedrijven vindt plaats op grotere bedrijven (figuur 3.7). Meer dan driekwart van de duurzame energie wordt toegepast op grote (4-8 ha) en zeer grote ( $>8 \mathrm{ha}$ ) bedrijven. De hoeveelheid duurzame energie toegepast door kleine ( 1 -2 ha) en zeer kleine ( $<1 \mathrm{ha}$ ) bedrijven bedroeg in $20184 \%$. Het voorgaande hangt onder meer samen met de relatief hoge investeringen die gepaard gaan met duurzame energie, waardoor dit voor kleinere bedrijven moeilijker te realiseren is. Van de 255 bedrijven die in 2018 duurzame energie toepasten, behoorden er 41 tot de groep van zeer grote bedrijven. Samen namen de bedrijven uit deze groep meer dan de helft (53\%) van de toegepaste duurzame energie voor hun rekening. Dit was vooral aardwarmte. De toepassing door kleine en zeer kleine bedrijven betrof hoofdzakelijk warmte uit biobrandstof en herwinning van zonnewarmte.

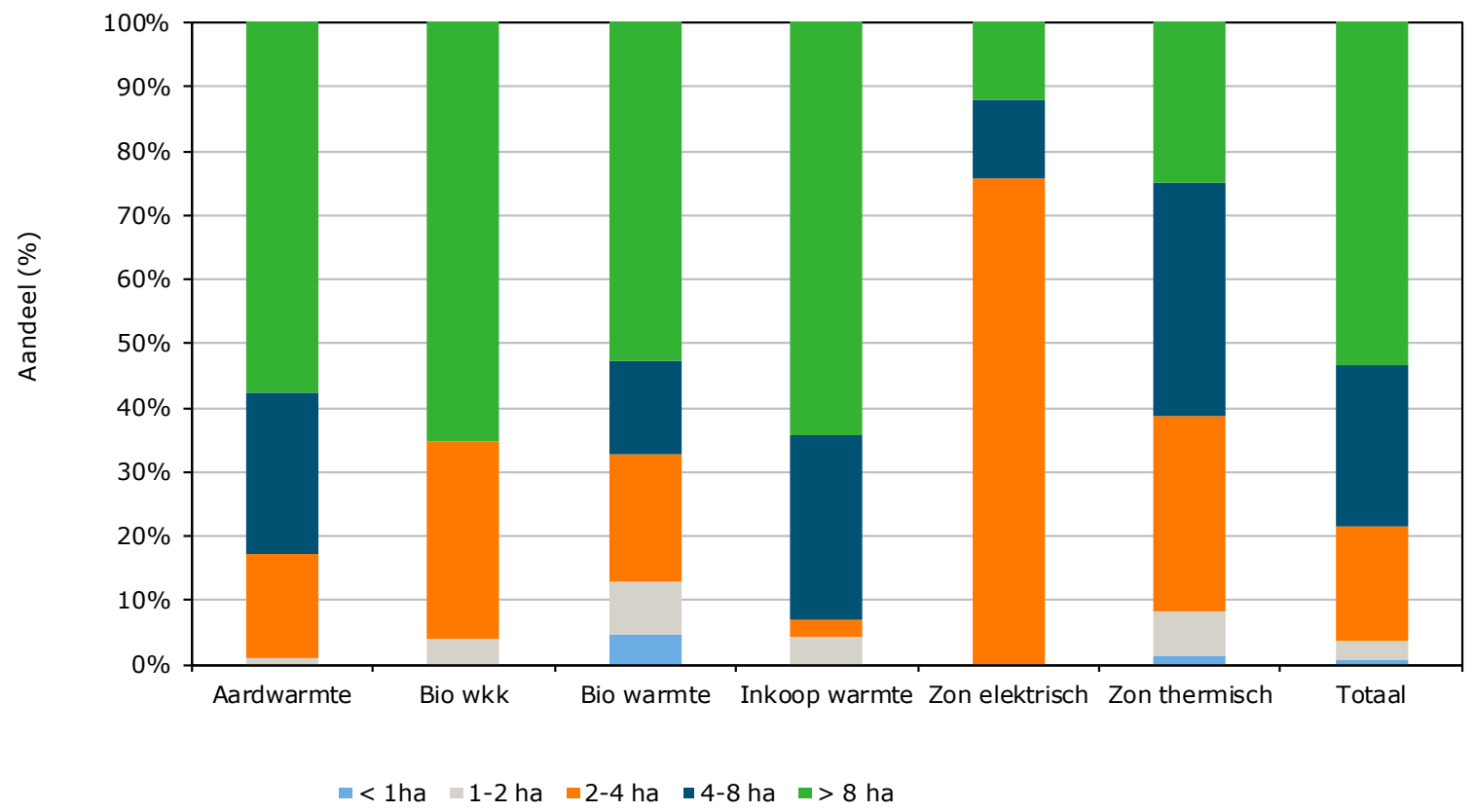

Figuur 3.7 Verdeling volume duurzame energie over bedrijfsgrootteklassen per vorm in 2018 (\%) v) v) Cijfer voorlopig.

\subsection{Reductie $\mathrm{CO}_{2}$-emissie}

Productie, inkoop en verkoop van duurzame energie door de glastuinbouw reduceert zowel binnen als buiten de glastuinbouw de $\mathrm{CO}_{2}$-emissie. Verandering van de $\mathrm{CO}_{2}$-emissie kan zowel op sectorniveau (op basis van de IPCC-methode) als op nationaal niveau (op basis van het primair brandstofverbruik) worden uitgedrukt. De reductie van de $\mathrm{CO}_{2}$-emissie door duurzame energie op sectorniveau bedroeg in 2018 0,32 Mton en de nationale reductie 0,47 Mton (tabel 3.2). Uit de tabel blijkt ook dat op sectorniveau aardwarmte de grootste bijdrage levert. Op nationaal niveau leveren inkoop duurzame elektriciteit en aardwarmte de grootste bijdrage. Dit komt doordat inkoop en productie van duurzame elektriciteit substitueert met inkoop van niet-duurzame elektriciteit en de inkoop van elektriciteit bij de IPCC-methode niet in beschouwing wordt genomen. 
Tabel 3.2 Reductie $\mathrm{CO}_{2}$-emissie per duurzame energiebron in $2018 \mathrm{v}$ )

\begin{tabular}{|c|c|c|c|c|}
\hline \multirow[t]{2}{*}{ Duurzame energiebron } & \multicolumn{2}{|c|}{ Sectoraal / IPPC methode } & \multicolumn{2}{|c|}{$\begin{array}{l}\text { Nationaal /Primair Brandstof } \\
\text { methode }\end{array}$} \\
\hline & Mton & $\%$ & Mton & $\%$ \\
\hline Zonne-energie (elektriciteit) & - & 0 & 0,01 & 1 \\
\hline Zonne-energie (warmte) & 0,04 & 13 & 0,01 & 3 \\
\hline Biobrandstof (warmte) & 0,03 & 9 & 0,03 & 6 \\
\hline Inkoop duurzaam gas & $<0,01$ & 1 & $<0,01$ & $<1$ \\
\hline Inkoop duurzame elektriciteit & - & 0 & 0,18 & 38 \\
\hline Inkoop duurzame warmte (centraal) & 0,01 & 2 & 0,01 & 1 \\
\hline
\end{tabular}

v) Cijfers 2018 voorlopig.

In de periode 2005-2018 nam de bijdrage die duurzame energie heeft in de reductie van de $\mathrm{CO}_{2}-$ emissie op sectorniveau (IPCC-methode) geleidelijk toe van 0,02 tot 0,32 Mton (figuur 3.8).

Hierbinnen was in 2018 de reductie door de productie van duurzame energie iets groter dan de reductie door inkoop van duurzame energie. Een van de kenmerken van de IPCC-methode is dat ingekochte elektriciteit niet meetelt. Op nationaal niveau (primair brandstof) nam de bijdrage die duurzame energie in de reductie van de $\mathrm{CO}_{2}$-emissie in de periode 2005-2018 toe van 0,05 Mton tot 0,46 Mton (figuur 3.8). Een van de kenmerken van deze indicator is dat als elders de inzet primair brandstof verandert door verandering van de energiehuishouding van de glastuinbouw, zoals inkoop elektriciteit, dit wel van invloed is. Over alle jaren is de reductie op nationaal niveau groter dan op sectorniveau. Dit komt doordat op nationaal niveau de inkoop van duurzame elektriciteit wel meetelt. In 2010 en 2017 was het verschil groter dan in andere jaren. In deze jaren was er een sterke toename van inkoop duurzame elektriciteit gevolg door een daling in het jaar er na.

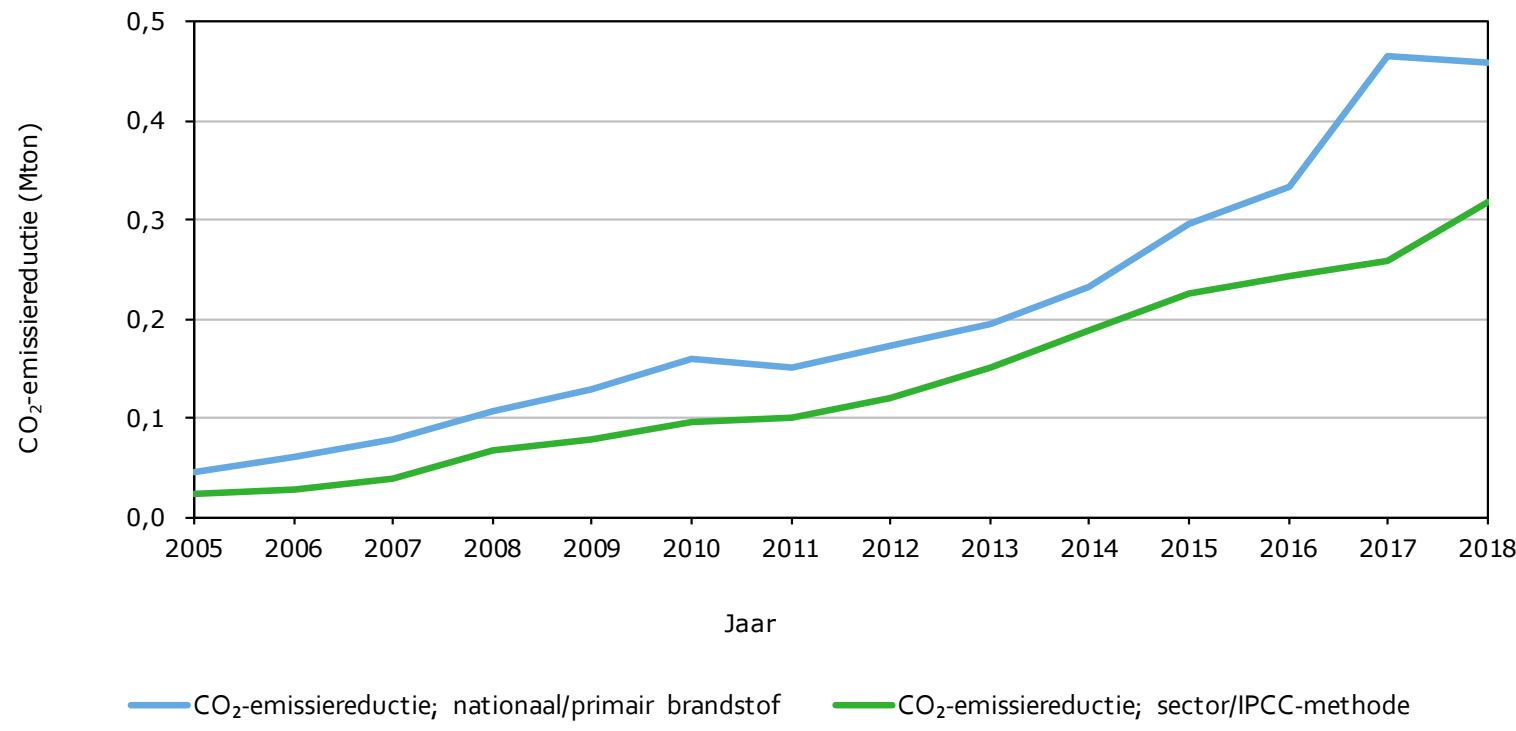

Figuur 3.8 Ontwikkeling reductie $\mathrm{CO}_{2}$-emissie van de glastuinbouw door duurzame energie op basis van primair brandstof en IPCC-methode $v$ )

v) Cijfers 2018 voorlopig.

Duurzame energie had in 2018 een positieve bijdrage aan verbetering van de energie-efficiëntie van de glastuinbouw met ruim 4 procentpunten. 


\subsection{Warmtedekking}

Een duurzame warmtebron voorziet in de glastuinbouw, op het areaal waar de bron wordt ingezet, in een deel van de warmtevraag. De mate waarin in de warmtevraag wordt voorzien wordt de dekking genoemd en wordt uitgedrukt in $\mathrm{m}^{3}$ a.e. per $\mathrm{m}^{2}$. De dekking bepaalt de reductie van de $\mathrm{CO}_{2}$-emissie in $\mathrm{kg} \mathrm{CO}_{2}$ per $\mathrm{m}^{2}$ kas door de duurzame warmtebron.

De dekking wordt beïnvloed door: (1) de warmtevraag, (2) het absolute vermogen van de bron, (3) de gebruiksduur van de bron, (4) het areaal dat de bron van warmte voorziet en (5) de $\mathrm{CO}_{2}$ voorziening. In 2018 was de gemiddelde dekking met duurzame warmte op het areaal met deze bronnen $15 \mathrm{~m}^{3}$ a.e. per $\mathrm{m}^{2}$. Rondom dit gemiddelde zit een grote spreiding.

\section{Verschillen tussen warmtebronnen}

De dekking verschilt per project en per duurzame bron. Bij projecten met zonnewarmte is de dekking laag en de spreiding tussen projecten klein. Dit komt door de functionele verbinding met de teelt (koeling). Bij projecten met inkoop van duurzame warmte is de dekking relatief hoog en de spreiding klein. Dit komt door de contractvoorwaarden en afspraken tussen afnemer en leverancier. Bij projecten met aardwarmte en biobrandstof is de spreiding groot. Dit heeft meerdere oorzaken. Ten eerste hebben deze bronnen geen functionele verbinding met de teelt, zoals bij zonnewarmte. Ten tweede is bij deze bronnen de projectoptimalisatie anders. Er zijn projecten met aardwarmte en biobrandstof die ingericht zijn om een maximale invulling van de warmtevraag per $\mathrm{m}^{2}$ op het glastuinbouwbedrijf te realiseren en er zijn projecten die een maximale benutting van de warmtebron nastreven. Bij maximale invulling is de dekking hoger, maar is er vooral in de zomerperiode onbenut warmtevermogen. Bij maximale benutting is de dekking lager en zal er in de winterperiode meer warmte nodig zijn vanuit andere warmtebronnen.

\section{Maximale benutting duurzame warmtebron}

Deze variant is vooral de laatste jaren populair. Enerzijds is bij maximale benutting de gebruiksduur langer en is ondersteuning vanuit de SDE+-regeling het grootst. Bij het maximeren van de gebruiksduur hoort een kleinere warmtecapaciteit $\left(\mathrm{W} / \mathrm{m}^{2}\right)$ en is de bijbehorende warmtedekking laag. Anderzijds is het voor financiers en projectpartners belangrijk dat het projectrisico door meerdere bedrijven wordt gedragen. Hierdoor worden meer bedrijven en een groter areaal aangesloten en is de warmtecapaciteit $\left(\mathrm{W} / \mathrm{m}^{2}\right)$ kleiner. Voor aardwarmte komt daar nog bij dat de regelbaarheid beperkt is, in vergelijking met bijvoorbeeld aardgas wkk. Ook is belangrijk dat bij een lage dekking van de duurzame warmtebron gasgestookte wkk's elektriciteit en rookgas $\mathrm{CO}_{2}$ kunnen blijven produceren en de warmte benut kan blijven worden. In 2018 werd ruim 90\% van het areaal met geothermie ook voorzien van energie en $\mathrm{CO}_{2}$ vanuit de wkk. Hiernaast heeft het grootste deel van het areaal met duurzame warmte zonder wkk toegang tot centraal aangeleverde externe $\mathrm{CO}_{2}$.

\section{Gerealiseerde dekkingen}

De warmtedekking van de afzonderlijke duurzame warmtebronnen is verschillend en de mix van de afzonderlijke bronnen in de totale hoeveelheid duurzame warmte is de afgelopen jaren veranderd. Hierdoor dient de ontwikkeling van de dekking in de tijd per bron te worden bezien. Uit de achterliggende data van de bestaande projecten met duurzame warmte (paragraaf 3.2) blijkt dat de gemiddelde dekking van de meeste duurzame warmtebronnen in de periode 2014-2018 is gedaald. Ter illustratie is dit in figuur 3.9 weergegeven voor aardwarmte. 


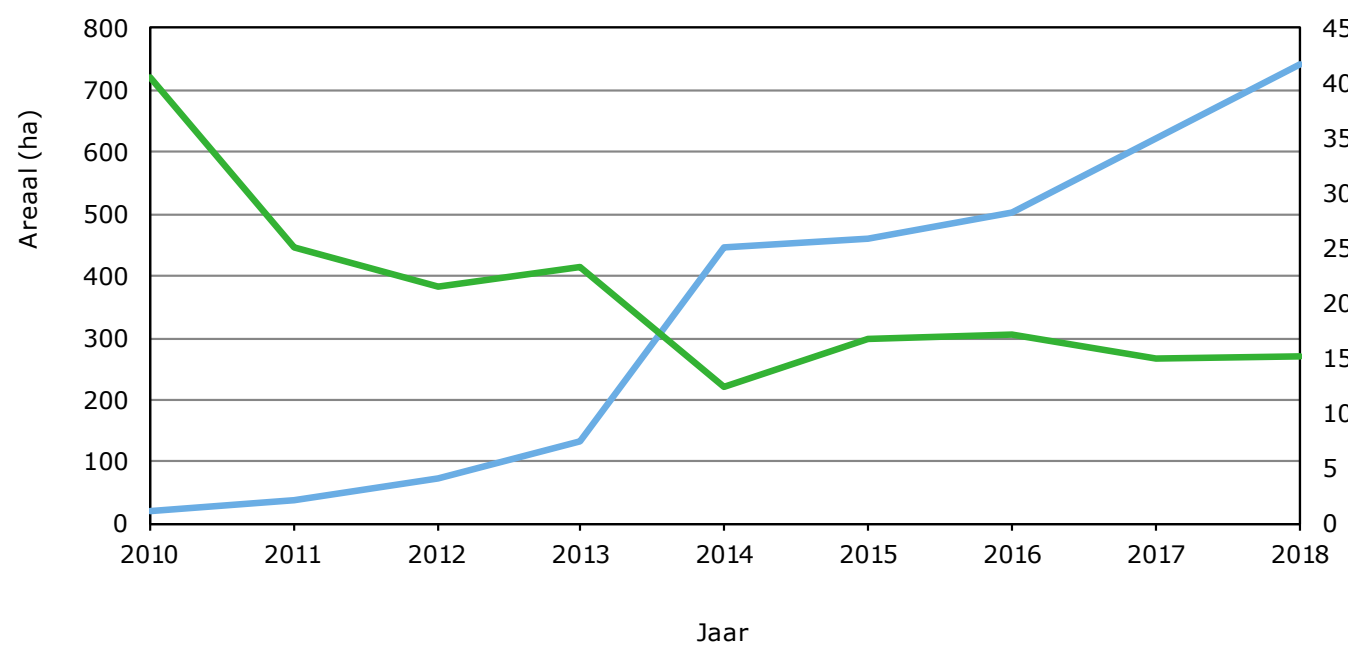

Figuur 3.9 Ontwikkeling van het areaal met aardwarmte en de gemiddelde warmtedekking van aardwarmteprojecten in de Nederlandse glastuinbouw $v$ )

v) Cijfers 2018 voorlopig.

\section{Nadelen}

Maximale benutting van een duurzame bron heeft naast voordelen ook nadelen. Het is voor te stellen dat op een gegeven moment het totale areaal met een beperkte basislast door een warmtebron zonder $\mathrm{CO}_{2}$-emissie voorzien wordt. $\mathrm{Er}$ is dan veel areaal met gebruik van deze warmte, maar de mate waarin reductie van de $\mathrm{CO}_{2}$-emissie per $\mathrm{m}^{2}$ plaatsvindt is beperkt (figuur 3.9). De noodzakelijke groei van het gebruik van duurzame warmte loopt dan tegen grenzen aan. Dit is een knelpunt voor het realiseren van de doelen en ambities van de $\mathrm{CO}_{2}$-emissiereductie op sectorniveau.

\subsection{Inkoop $\mathrm{CO}_{2}$}

Naast de uitstoot van $\mathrm{CO}_{2}$ gebruikt de glastuinbouw $\mathrm{CO}_{2}$ als meststof voor de optimale productie van de gewassen. Deze $\mathrm{CO}_{2}$ is in de huidige situatie vooral afkomstig van de rookgassen van aardgasgestookte wkk's en ketels in de glastuinbouw. Bij het vervangen van fossiele brandstof door energiebronnen zonder $\mathrm{CO}_{2}$-emissie, valt de $\mathrm{CO}_{2}$-voorziening - en daarmee een essentiële productiefactor - weg. De overgang naar duurzame energie en inkoop van warmte kan daardoor niet zonder het gebruik van externe $\mathrm{CO}_{2}$. Hiernaast kan de inzet van externe $\mathrm{CO}_{2}$ de zomerstook verminderen en gebruiken glastuinbouwbedrijven die het mogelijke risico van schadelijke elementen in de rookgassen te groot achten externe $\mathrm{CO}_{2}$. Met zomerstook wordt de $\mathrm{CO}_{2}$-productie uit aardgas zonder warmtebenutting bedoeld en het vermijden hiervan is energiebesparing (paragraaf 2.5).

In 2018 werd zo'n 0,64 Mton $\mathrm{CO}_{2}$ extern ingekocht en dat is bijna $10 \%$ meer dan in 2017. In de periode 2009-2013 nam de jaarlijkse inkoop af, maar vanaf 2013 is er weer groei. De eerdere daling hangt waarschijnlijk samen met de krimp van het areaal en de lagere economische groei. De toename vanaf 2013 duidt er op dat bedrijven meer $\mathrm{CO}_{2}$ inkopen voor productie-optimalisatie en energieverduurzaming in een periode met betere economische omstandigheden en vooruitzichten. De gemiddelde toepassing van externe $\mathrm{CO}_{2}$ nam op het totale areaal glastuinbouw in 10 jaar met meer dan $40 \%$ toe tot ruim $7 \mathrm{~kg}$ per $\mathrm{m}^{2}$ in 2018 . Ruim $30 \%$ van het areaal met duurzame energie is te vinden in de gebieden met centrale levering van externe $\mathrm{CO}_{2}$.

Voor de verdere ontwikkeling van het gebruik van duurzame energie en warmte van derden is toename van de externe $\mathrm{CO}_{2}$-voorziening en verhoging van de leveringszekerheid van groot belang. Externe $\mathrm{CO}_{2}$ komt beschikbaar als bijproduct van industriële processen. Onderscheid is te maken tussen $\mathrm{CO}_{2}$ van fossiele en van biogene oorsprong; beiden komen voor. Daarnaast is onderscheid te 
maken naar rookgassen en zuivere $\mathrm{CO}_{2}$ en tussen centrale en decentrale levering (figuur 3.10). Het gebruik van externe $\mathrm{CO}_{2}$ in de glastuinbouw betreft vooral centrale levering van zuivere $\mathrm{CO}_{2}$ via een leidingnet. De hoeveelheid rookgas $\mathrm{CO}_{2}$ is zeer beperkt. Decentraal zuiver $\mathrm{CO}_{2}$ aangeleverd per as neemt een tussenpositie in. De groei van de inzet van externe $\mathrm{CO}_{2}$ zat in 2018 vooral bij de centrale levering van zuivere $\mathrm{CO}_{2}(+13 \%)$.

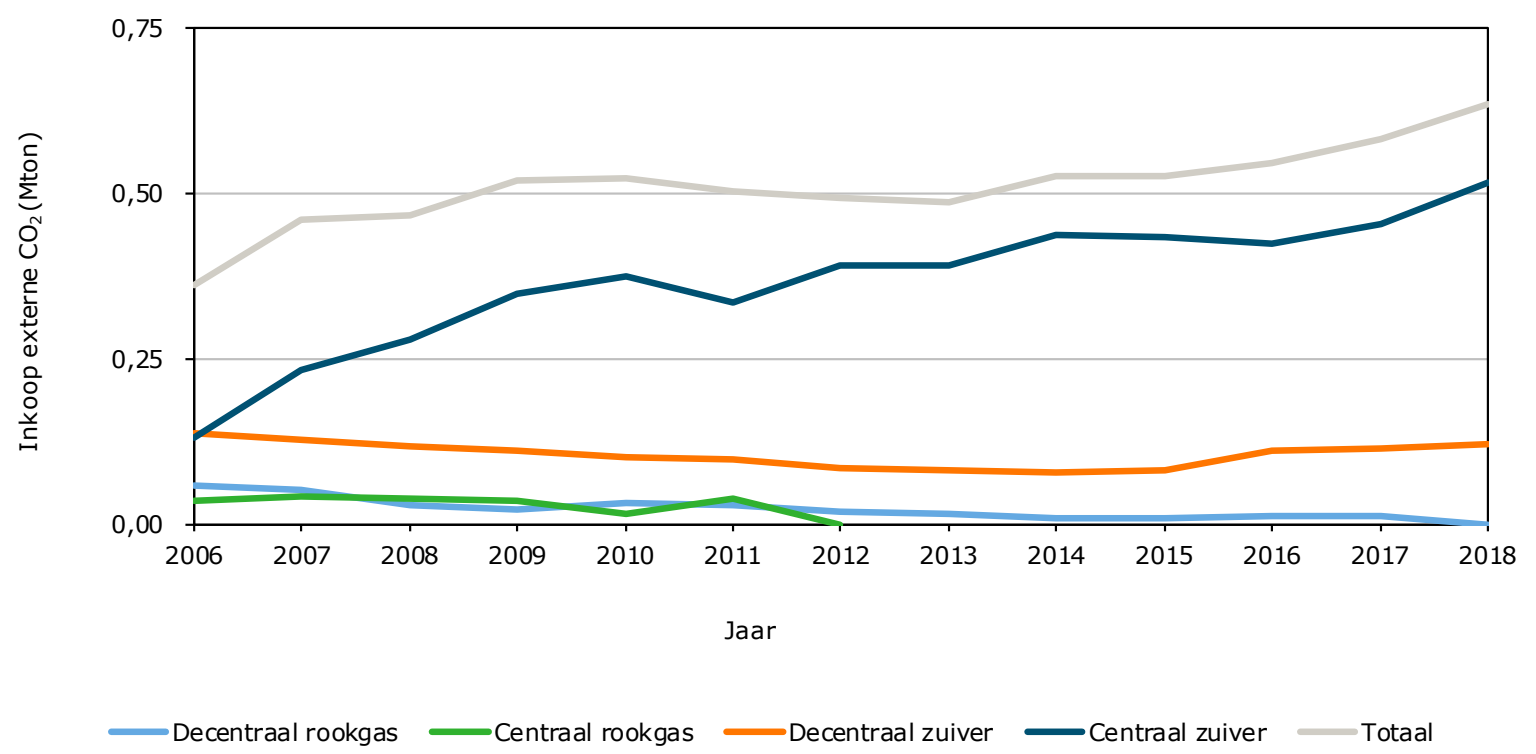

Figuur 3.10 Ontwikkeling van de inkoop van externe $\mathrm{CO}_{2}$ door de Nederlandse glastuinbouw $v$ ) v) Cijfers 2018 voorlopig. 


\section{$4 \quad$ Nadere analyse wkk, inkoop van warmte en elektriciteitsbalans}

\subsection{Inleiding}

De glastuinbouw maakt op grote schaal gebruik van warmtekrachtkoppeling (wkk). Met wkk wordt warmte en elektriciteit geproduceerd. De warmte die vrijkomt bij elektriciteitsproductie met fossiele brandstof wordt hiermee nuttig gebruikt (Smit en Van der Velden, 2008). Ook kan de $\mathrm{CO}_{2}$ uit rookgassen benut worden voor de groei van het gewas.

Het gebruik van wkk in de glastuinbouw betreft vooral aardgasmotoren van de glastuinbouwbedrijven (paragraaf 4.2). In deze rapportage worden met wkk deze installaties bedoeld ${ }^{4}$. Daarnaast wordt gebruik gemaakt van restwarmte van elektriciteitscentrales of industrie en wordt op zeer beperkte schaal gebruik gemaakt van warmte uit wkk's in beheer van energiebedrijven. Bij deze laatste drie vormen koopt de glastuinbouw warmte (paragraaf 4.3) en eventueel $\mathrm{CO}_{2}$ in.

Door de inkoop van warmte wordt de $\mathrm{CO}_{2}$-emissie van de glastuinbouw (IPCC-methode) en het primair brandstofverbruik - en dus de nationale $\mathrm{CO}_{2}$-emissie - verminderd (paragraaf 4.4). Door wkk van de glastuinbouw wordt ook primair brandstof bespaard en dus de nationale $\mathrm{CO}_{2}$-emissie verlaagd. De wkk's gebruiken aardgas en dit verhoogt de $\mathrm{CO}_{2}$-emissie van de glastuinbouw (IPPC-methode).

De exploitatie van wkk door glastuinbouwbedrijven is sinds jaren van grote invloed op de elektriciteitsbalans en op de energiekosten van de glastuinbouw. De elektriciteitsbalans wordt behandeld in paragraaf 4.5 en de energiekosten zijn behandeld in paragraaf 2.6. Op beperkte schaal gebruikt de glastuinbouw ook wkk's die draaien op biobrandstof en wordt er duurzame warmte ingekocht van wkk's van derden die draaien op biobrandstof. Dit is duurzame energie en is in beschouwing genomen bij duurzame energie in hoofdstuk 3 en maakt geen deel uit van de cijfers in hoofdstuk 4, tenzij anders aangegeven.

\subsection{Wkk glastuinbouwbedrijven}

\section{Vermogen en areaal}

Het totale elektrische vermogen van de wkk van tuinders vertoont sinds 2014 fluctuaties, maar ook een dalende trend. In de jaren 2012-2014 was er zo'n 2.500 MWe in gebruik. In de jaren 2015-2018 lag het totaal vermogen met ruim $2.400 \mathrm{MW}_{\mathrm{e}}$ op een wat lager niveau. De daling is vooral veroorzaakt door krimp van het areaal. De krimp van het areaal zat vooral bij de bedrijven met snijbloemen, waar relatief veel belichting werd toegepast. In 2017 had circa 63\% van het totaal glastuinbouwareaal een wkk op aardgas in gebruik.

\section{Gebruik elektriciteit}

De door de wkk's van glastuinbouwbedrijven geproduceerde elektriciteit werd in 2018 voor circa 60\% op de elektriciteitsmarkt verkocht en voor circa $40 \%$ door de glastuinbouw zelf gebruikt. Het eigen gebruik hangt hoofdzakelijk samen met het gebruik van groeilicht. Verkoop van elektriciteit vindt plaats bij vrijwel alle bedrijven met een wkk. Door bedrijven zonder groeilicht wordt bijna alle elektriciteit verkocht, door bedrijven met groeilicht wordt meer zelf gebruikt en minder verkocht dan door bedrijven zonder groeilicht.

\section{Verkoop elektriciteit en $\mathrm{CO}_{2}$-dosering}

De verkoop van elektriciteit vindt vooral overdag plaats. In deze uren is de elektriciteitsprijs hoger. Bovendien past dit bij de behoefte aan $\mathrm{CO}_{2}$ die de gewassen juist overdag hebben. De gereinigde

\footnotetext{
4 Een beperkt deel van de wkk's in gebruik op glastuinbouwbedrijven is ondergebracht in aparte "energie bv's". In de Energiemonitor Glastuinbouw worden deze installaties beschouwd als wkk's van de glastuinbouw (zie Protocol).
} 
rookgassen van de wkk's worden op grote schaal toegepast voor $\mathrm{CO}_{2}$-dosering bij de gewassen. Door het gebruik van wkk komt er per eenheid warmte meer $\mathrm{CO}_{2}$ beschikbaar dan bij warmteproductie met de aardgasketel. Er wordt immers ook aardgas verbrand voor elektriciteitsproductie. Deze extra rookgas $\mathrm{CO}_{2}$ is gunstig voor de groei van het gewas en hiermee de ontwikkeling van de fysieke productie (paragraaf 2.2).

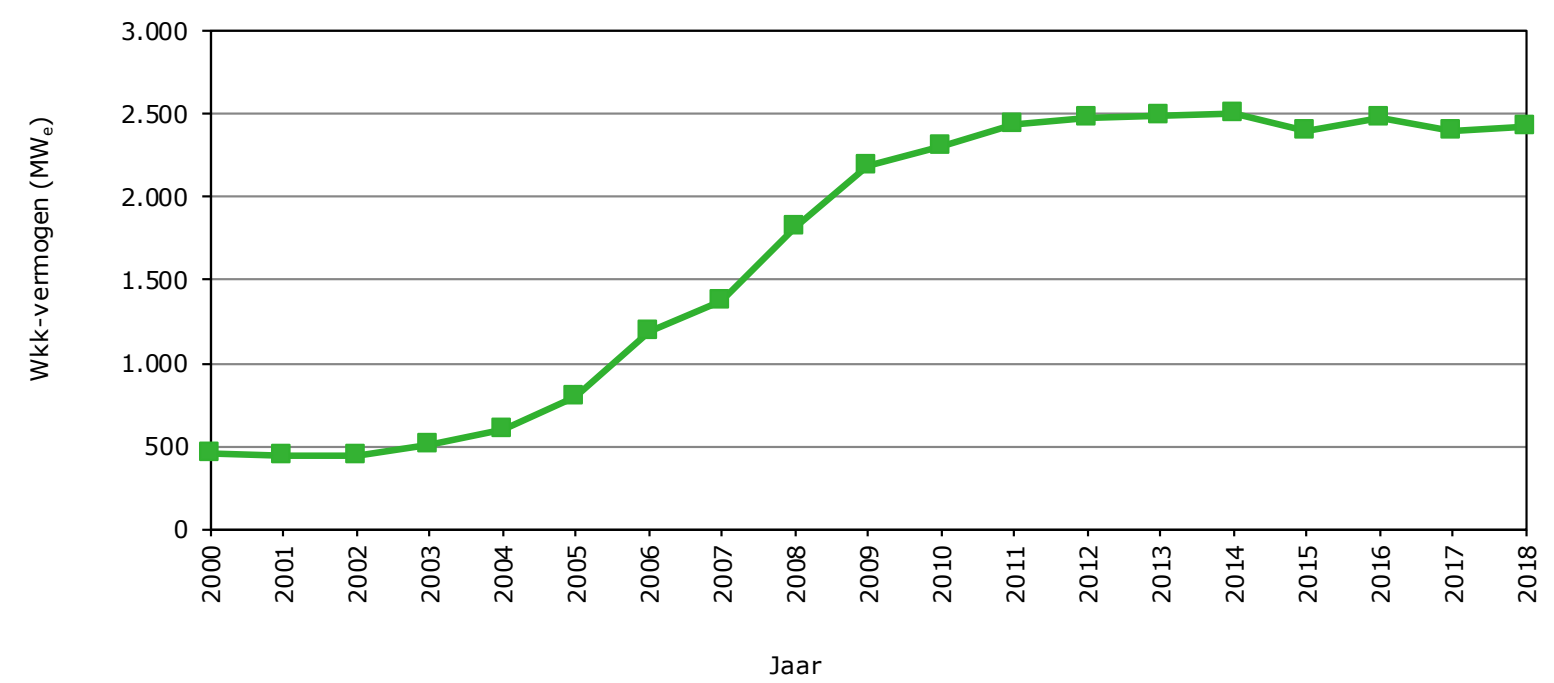

Figuur 4.1 Wkk-vermogen glastuinbouw

Bron: Landbouwtelling, bewerking Wageningen Economic Research.

\section{Gebruiksduur}

In 2018 bedroeg de gemiddelde gebruiksduur (equivalente vollast-uren per jaar) van de wkk's bijna 3.900 uur. De gebruiksduur liet in de periode 2011-2016 een dalende trend zien (figuur 4.2). Deze ontwikkeling hing samen met de voor wkk ongunstige spark spread (paragraaf 2.6). Hierdoor waren er op jaarbasis minder uren waarin het aantrekkelijk was om elektriciteit te verkopen. De sterkste daling vond plaats in 2014. In 2016 lag de gemiddelde gebruiksduur op zo'n 3.300 uur; dat is 20\% lager dan in 2011 . In 2017 en 2018 is de gebruiksduur toegenomen. Dit kwam vooral door de verbeterde spark spread. Naast de verkoop nam door groei van de belichting ook de consumptie van de elektriciteitsproductie met wkk's door de glastuinbouwbedrijven toe. De gemiddelde gebruiksduur lag in 2018 bijna 600 uur (18\%) hoger dan in 2016.

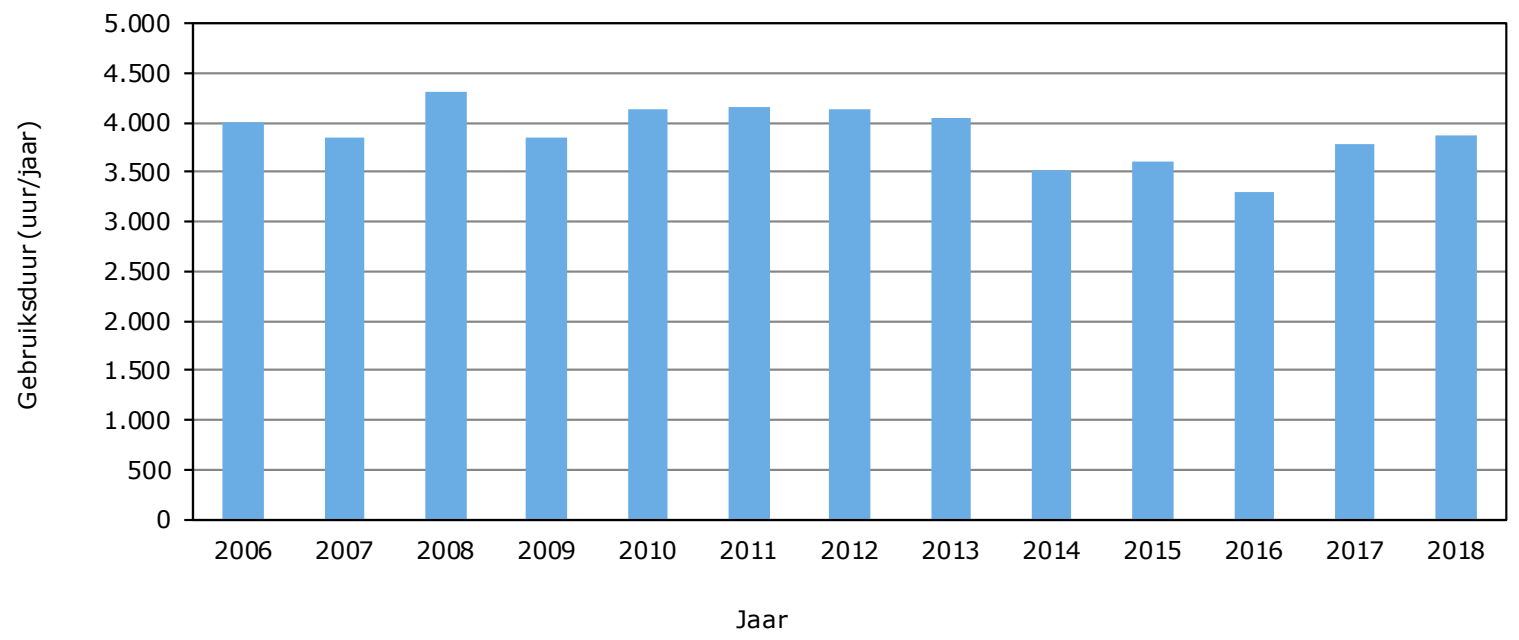

Figuur 4.2 Globale gemiddelde gebruiksduur wkk tuinders a)

a) Cijfers 2018 voorlopig. 


\subsection{Inkoop van warmte}

De glastuinbouw koopt warmte in van elektriciteitscentrales, industrie en wkk's in beheer van energiebedrijven. In 2018 werd totaal 3,4 PJ warmte ingekocht bij leveranciers van buiten de glastuinbouw (figuur 4.3). Dit is 3,4\% van het totale energiegebruik en $4,4 \%$ van de warmteconsumptie door de glastuinbouw. De ingekochte warmte was bijna volledig afkomstig van elektriciteitscentrales en industrie.

De inkoop van warmte neemt sinds het einde van de vorige eeuw af. Vanaf 2014 liet de inkoop van warmte van een lichte toename zien. Dit kwam door uitbreiding van het areaal kassen bij bestaande warmteprojecten en door de lagere buitentemperatuur in deze jaren. De inkoop van warmte van wkk's van energiebedrijven nam verder af omdat installaties uit gebruik werden genomen of aan tuinders werden overgedragen. In 2018 was het vermogen van wkk's in beheer bij energiebedrijven met circa $10 \mathrm{MW}_{\mathrm{e}}$ nog maar zeer beperkt van omvang, terwijl er rond de eeuwwisseling nog ruim $500 \mathrm{MW}_{\mathrm{e}}$ door energiebedrijven in gebruik was. Dit hangt samen met de liberalisering van de energiemarkt, de splitsing en focus van energiebedrijven.

Een deel van de ingekochte warmte werd door de centrales geproduceerd met biobrandstof. Dit is hier buiten beschouwing gelaten en telt mee als inkoop van duurzame energie (hoofdstuk 3 ).

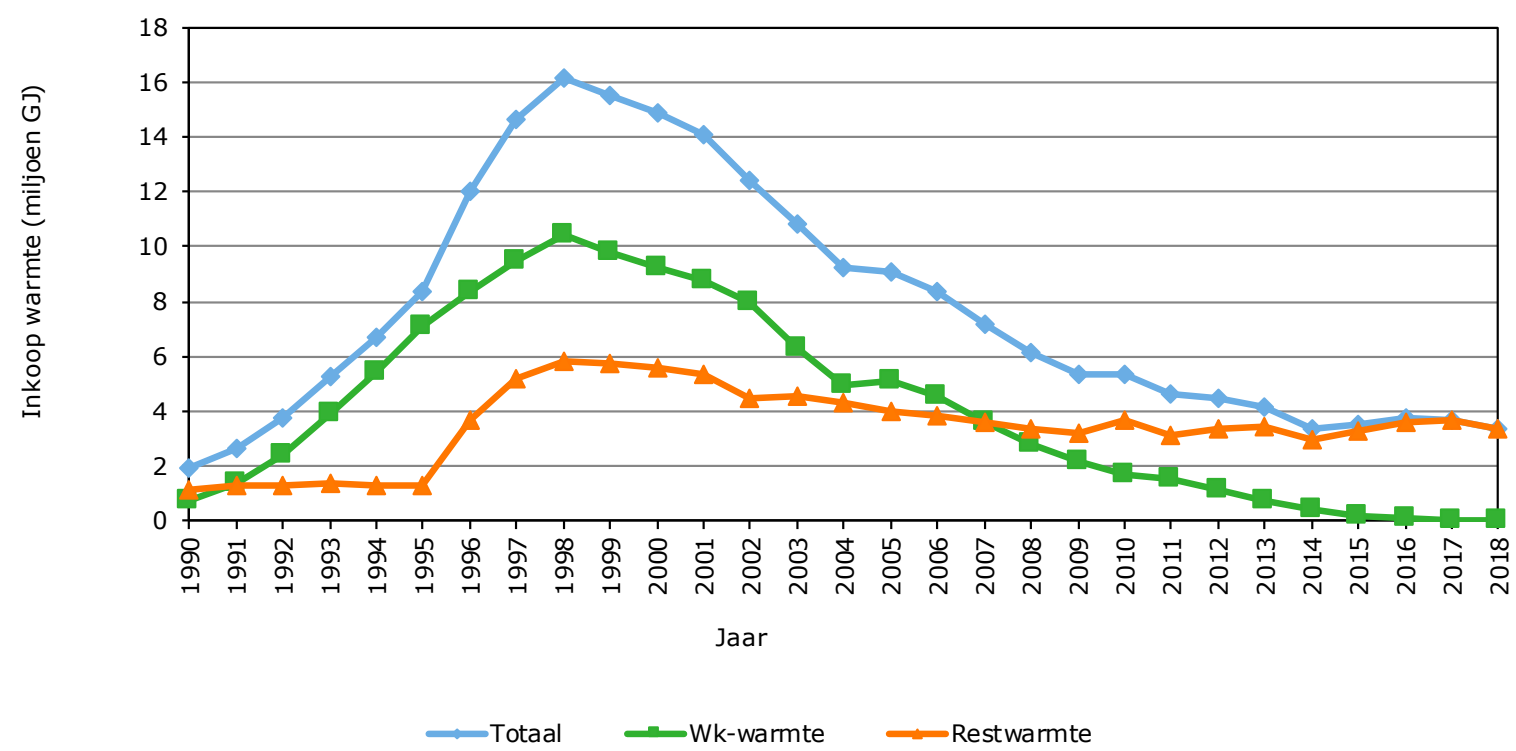

Figuur 4.3 Inkoop van warmte door de glastuinbouw a)

a) Cijfers 2018 voorlopig.

\subsection{Reductie $\mathrm{CO}_{2}$-emissie}

\section{Achtergronden}

De reductie van de $\mathrm{CO}_{2}$-emissie door wkk kan op twee manieren worden bepaald. De ene insteek is de $\mathrm{CO}_{2}$-emissie c.q. het fossiele brandstofverbruik op sectorniveau. De andere insteek is de $\mathrm{CO}_{2}$-emissie nationaal c.q. het primair brandstofgebruik. De effecten van de inzet van wkk door de tuinbouw zijn van invloed op de $\mathrm{CO}_{2}$-emissie binnen en buiten de glastuinbouw. Er wordt aardgas ingekocht en elektriciteit verkocht. Hierdoor neemt de $\mathrm{CO}_{2}$-emissie van de glastuinbouwsector toe (IPCC-methode), terwijl dit bij elektriciteitscentrales en de industrie afneemt. Het laatste effect is groter dan de toename van de emissie in de glastuinbouw, waardoor per saldo op nationaal niveau $\mathrm{CO}_{2}$-emissie wordt vermeden. Hierdoor is het effect van wkk en van inkoop warmte op de $\mathrm{CO}_{2}$-emissie op nationaal niveau gekwantificeerd op basis van het primair brandstofverbruik. 


\section{Wkk tuinders}

De wkk's van de tuinders reduceren het primair brandstofverbruik substantieel. In de periode voor 2012 is deze besparing toegenomen tot ruim 1,1 miljard $\mathrm{m}^{3}$ a.e. per jaar (figuur 4.4). Dit komt overeen met circa 30\% van het totale aardgasverbruik van de glastuinbouw en in 2012 . Na 2012 is de primair brandstofbesparing afgenomen. Door de afname van het totaal wkk-vermogen, de verminderde gebruiksduur, de toename van de elektriciteitsconsumptie door de glastuinbouw en de verminderde verkoop van elektriciteit, is de besparing in de peridode 2012-2016 teruggelopen tot 0,8 miljard $\mathrm{m}^{3}$ a.e. In 2017 en 2018 is door de toename van de gebruiksduur van en de verkoop van elektriciteit de reductie van het primair brandstofgebruik weer toegenomen tot circa 0,9 miljard $\mathrm{m}^{3}$ a.e. De besparing van het primair brandstofgebruik leidde in 2018 tot een reductie van de $\mathrm{CO}_{2}$-emissie van 1,6 Mton op nationaal niveau (tabel 4.1). In het jaar met de hoogste reductie (2012) lag de nationale reductie op het niveau van 2,0 Mton. Het effect op de energie-efficiëntie was in 2012 18 procentpunt en in 201814 procentpunt.

\section{Inkoop warmte}

De reductie van het primair brandstofverbruik door de inkoop van warmte van derden daalde in de periode 2005-2014 van bijna 200 naar 74 miljoen $\mathrm{m}^{3}$ a.e. (figuur 4.4). Na 2014 was er een lichte groei tot circa 86 miljoen $\mathrm{m}^{3}$ a.e. en in 2017 en 2018 een lichte afname tot 80 miljoen $\mathrm{m}^{3}$ a.e. in 2018. De inkoop van warmte droeg in 2018 voor 1 procentpunt bij aan de verbetering van de energieefficiëntie. De $\mathrm{CO}_{2}$-emissie van de glastuinbouw (fossiel brandstofverbruik) lag door inkoop van warmte in 2018 0,19 Mton lager en nationaal (primair brandstof) 0,14 Mton lager. Het laatste effect is kleiner door de extra uitstoot bij de centrales en de industrie door de productie van de warmte. Dit laatste telt wel mee op nationaal niveau (primair brandstof) en niet op sectorniveau (IPCC-methode).

Tabel 4.1 Reductie $\mathrm{CO}_{2}$-emissie door wkk en inkoop warmte in $2018 \mathrm{v}$ )

\begin{tabular}{lrr} 
Wkk bron & $\mathrm{CO}_{2}$-reductie nationaal / primair brandstof \\
\cline { 2 - 3 } Wkk-tuinders & Mton \\
\hline Inkoop warmte & 1,61 & 92 \\
\hline Totaal & 0,14 & $\mathbf{1 , 7 5}$ \\
\hline
\end{tabular}

v) Cijfers voorlopig.

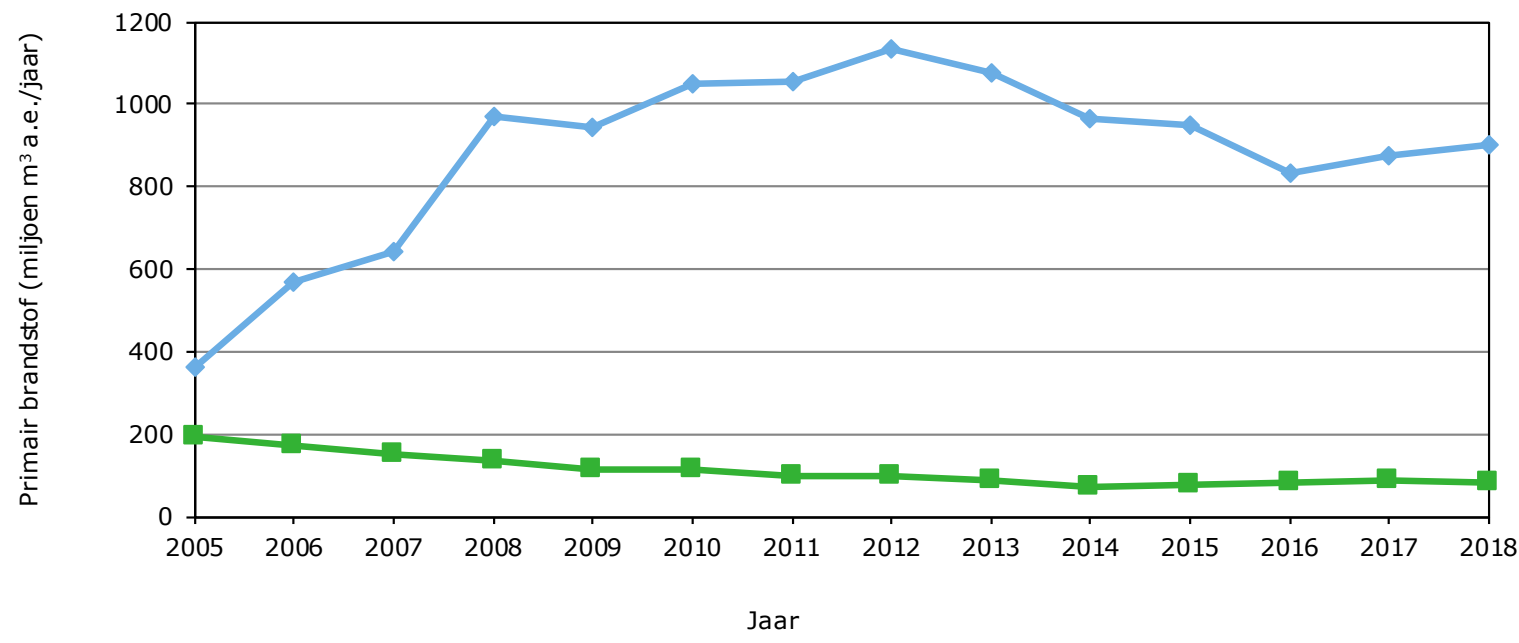

$\longrightarrow$ Wkk-aardgas $\quad$ Inkoop warmte

Figuur 4.4 Reductie primair brandstofverbruik door het gebruik van wkk door tuinders en door inkoop van warmte a)

a) Cijfers 2018 voorlopig. 


\subsection{Elektriciteitsbalans}

De elektriciteitsbalans bestaat uit de vier elementen productie, verkoop, inkoop en consumptie. In deze paragraaf worden deze elementen achtereenvolgens behandeld. De elektriciteitsbalans van 2018 is weergegeven in figuur 4.5 en de ontwikkeling over de jaren heen is opgenomen in figuur 4.6.

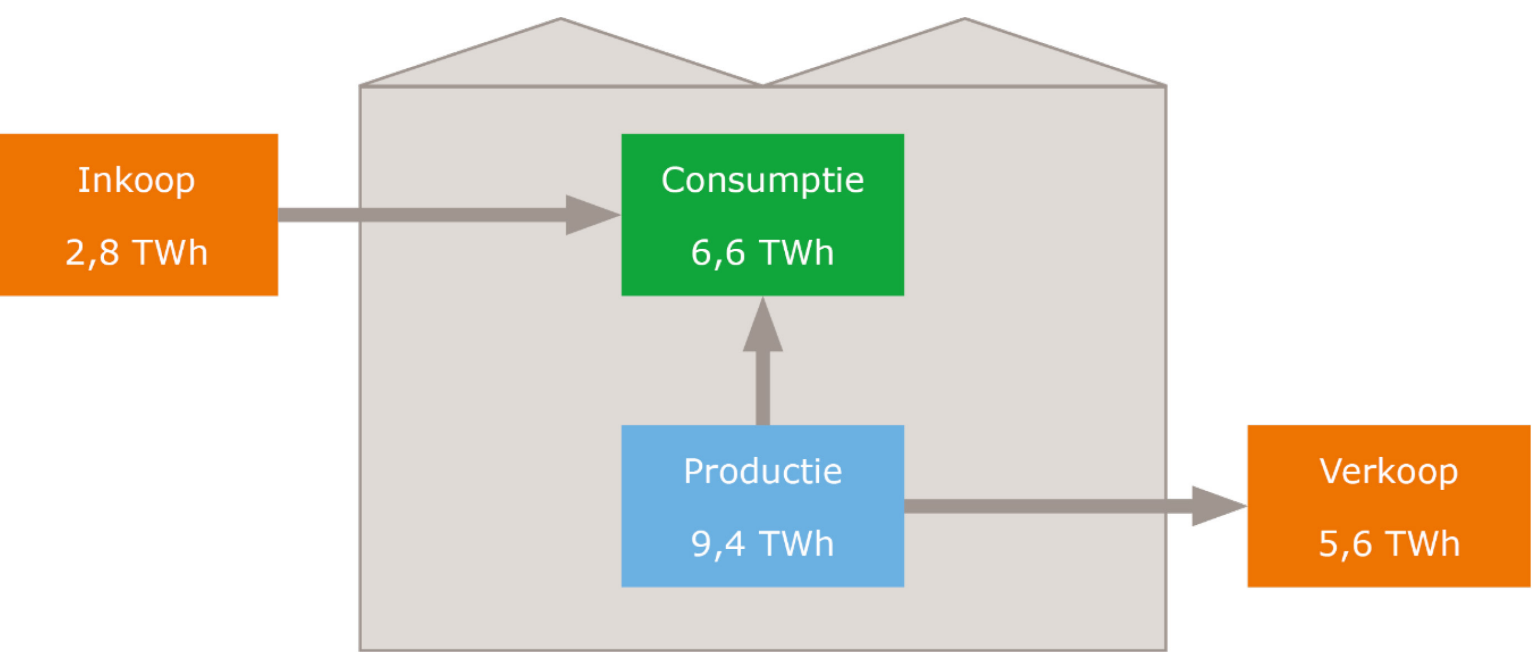

Figuur 4.5 Globale elektriciteitsbalans van de glastuinbouw in 2018 a)

a) Cijfers voorlopig.

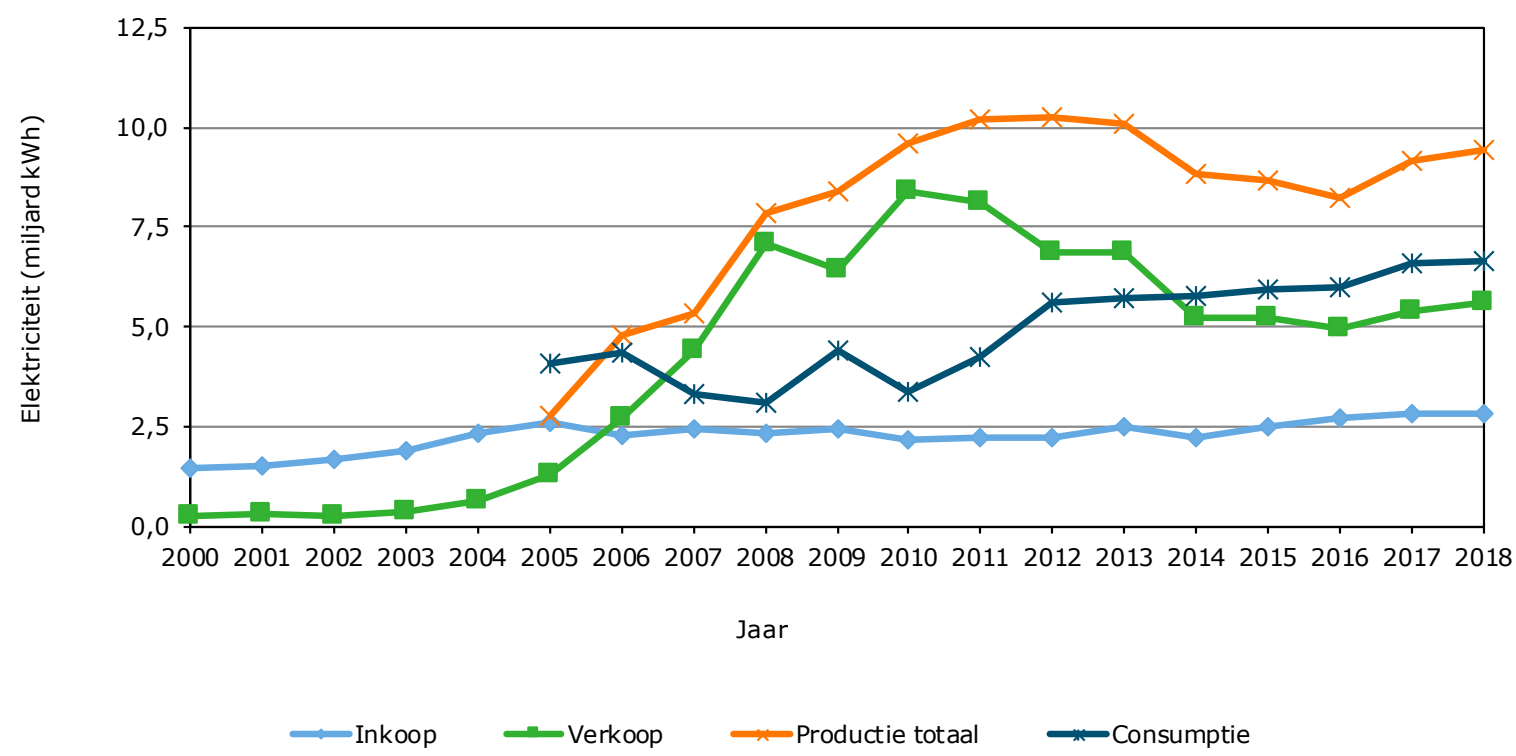

Figuur 4.6 Inkoop, verkoop, productie en consumptie van elektriciteit door de glastuinbouw a) a) De productie en de consumptie van voor 2005 zijn niet bekend; cijfers van 2018 zijn voorlopig.

De consumptie is berekend door de productie te verminderen met de verkoop en de inkoop er bij op te tellen. Eventuele statistische fouten in deze drie elementen werken hierbij door in de consumptie. De elektriciteitsbalans moet daardoor als een globale indicatie worden gezien en voor ontwikkelingen is het beter om een periode van meerdere jaren te bezien.

\section{Productie}

De elektriciteitsproductie door de glastuinbouw lag in de jaren 2010-2013 op gemiddeld circa 10 miljard kWh. Hierna daalde dit naar ruim 8 miljard kWh in 2016. De daling kwam door de vermindering van het totale wkk-vermogen, gecombineerd met een gemiddeld kortere gebruiksduur. 
Na 2016 groeide de productie weer naar ruim 9 miljard kWh in 2018. Dit kwam door de toename van de gebruiksduur door een gunstigere markt voor de verkoop van elektriciteit en toename van de inzet van groeilicht. Behalve met aardgas-wkk produceerde de glastuinbouw een geringe hoeveelheid duurzame elektriciteit met bio-wkk en met zonnecellen (hoofdstuk 3). De totale elektriciteitsproductie door de glastuinbouw voorzag in 2018 7,8\% van de totale Nederlandse elektriciteitsconsumptie. Per $\mathrm{m}^{2}$ kas kwam de totale productie in 2018 uit op gemiddeld circa $105 \mathrm{kWh}$.

Verkoop

De verkoop is in de periode 2010-2016 gedaald van 8,4 naar 5,0 miljard kWh. Deze daling van bijna $40 \%$ zat vooral in de jaren 2010-2014. In 2018 groeide de verkoop, door een betere spark spread voor wkk, naar circa 5,6 miljard kWh.

\section{Inkoop}

De inkoop van elektriciteit liet in de periode 2010-2017 een stijgende trend zien. In 2010 bedroeg de inkoop circa 2,2 en in 2017 2,8 miljard kWh. Dit is een stijging met bijna 30\%. Deze ontwikkeling hangt samen met de toename van het areaal met groeilicht, maar vooral de intensivering van groeilicht $\left(\mathrm{W} / \mathrm{m}^{2}\right)$. Om warmte uit de wkk maximaal te benutten werd niet alle benodigde elektriciteit zelf opgewekt, maar gedeeltelijk ingekocht. In 2018 bleef de inkoop gelijk. De oorzaken hiervan zijn niet duidelijk. Aspecten die hierbij een rol kunnen spelen zijn structuureffecten (veranderingen in areaal en aandeel belichting per gewas), meer buitenlicht, hetgeen kan leiden tot minder belichting in de winterperiode, de hogere prijs voor inkoop elektriciteit (paragraaf 2.6) en de verhoging van de energiebelasting.

\section{Netto-leverancier}

Sinds 2006 is er jaarlijks meer elektriciteit verkocht dan er is ingekocht en is de glastuinbouw nettoleverancier van elektriciteit. De netto-verkoop nam in de periode tot 2010 toe tot 6,2 miljard kWh en nam in de periode 2010-2016 af naar 2,3 miljard kWh. Dit is een daling van circa 36\%. In 2017 nam zowel de verkoop als de inkoop toe. In 2018 nam de verkoop ook toe, maar bleef de inkoop gelijk. Per saldo was de netto-verkoop in 2018 circa 2,8 miljard kWh.

\section{Consumptie}

De elektriciteitsconsumptie (productie plus inkoop minus verkoop) van de sector bedroeg in 2018 naar schatting 6,6 miljard $\mathrm{kWh}$. Dit is 5,5\% van de nationale consumptie. Per $\mathrm{m}^{2}$ kas bedroeg de consumptie gemiddeld $74 \mathrm{kWh}$. Ondanks de krimp van het areaal in de periode 2010-2018 groeide de absolute elektriciteitsconsumptie van de glastuinbouw dusdanig dat er bijna een verdubbeling was. Per $\mathrm{m}^{2}$ kas groeide de elektriciteitsconsumptie in de periode $2010-2018$ met $127 \%$.

De toename van de elektriciteitsconsumptie komt vooral door de toename van groeilicht (intensiteit en areaal) en in mindere mate door de inzet van duurzame energievoorzieningen, verdere optimalisering van het kasklimaat, mechanisatie en automatisering. Naast deze intensivering van de elektriciteitsconsumptie wordt er ook elektriciteitsbesparing gerealiseerd door bijvoorbeeld zuiniger belichtingstechnieken, slimme regelingen en schaalvergroting. Vanuit de toename van de consumptie kan geconcludeerd worden dat de intensivering groter was dan de besparing.

In de elektriciteitsconsumptie werd in 2018 voor circa $57 \%$ voorzien door eigen productie met wkk, de resterende $43 \%$ werd ingekocht. In de periode tot 2014 is de glastuinbouw in sterkere mate in de eigen elektriciteitsconsumptie gaan voorzien met wkk. In 2014 bedroeg dit aandeel circa 62\%. Vanaf 2014 toont dit aandeel een daling en neemt het aandeel inkoop toe. Dit hangt samen met de intensivering van groeilicht per $\mathrm{m}^{2}$ en het bereiken van grenzen van de warmtebenutting bij gebruik van warmte uit de wkk's in de kas. 


\subsection{Warmtegebruik en warmtedekking}

\section{Warmtebenutting wkk}

In 2017 en 2018 nam de verkoop van elektriciteit uit de wkk's toe (paragraaf 4.5). Door wkk's wordt de vrijkomende warmte bij de elektriciteitsproductie grotendeels benut. Uit een eerdere studie (Smit en Van der Velden, 2008) is gebleken dat elektriciteitsproductie met een wkk bedrijfseconomisch niet uit kan zonder deze warmtebenutting. Ook bij de prijzen voor inkoop aardgas en verkoop elektriciteit in 2017 en 2018 is dat het geval.

Bedrijven met belichting plannen wkk-draaiuren in blokken voor belichting. Buiten deze blokken kan elektriciteit worden verkocht als de warmte kan worden benut en de opbrengst van de elektriciteit opweegt tegen de productiekosten. Dit laatste geldt ook voor bedrijven zonder belichting. In de winter is er meer verkoop mogelijk omdat de warmtevraag in de winter groter is. Uit analyse van maandgegevens blijkt dat de extra elektriciteitsproductie in 2017 en in 2018 vooral plaatsvond in de koudere winterperiode en specifiek in de maanden met een lagere buitentemperatuur dan het jaar ervoor. In deze perioden kon de warmte dus worden benut. Uit het voorgaande kan worden afgeleid dat de extra elektriciteitsverkoop in 2017 en 2018 gepaard ging met substantiële benutting van warmte afkomstig van wkk.

\section{Warmtedekking}

In de glastuinbouw is circa $2.400 \mathrm{MW}_{\mathrm{e}}$ aan wkk-vermogen op circa $63 \%$ van het areaal in gebruik. In 2018 werd op dit areaal gemiddeld $22 \mathrm{~m}^{3}$ a.e. per $\mathrm{m}^{2}$ kas warmte uit de wkk's benut. De ingekochte warmte van de centrales en de industrie (3,5 PJ) (paragraaf 4.23) werd in 2018 toegepast op bijna 500 ha kassen. Op dit areaal werd gemiddeld zo'n $23 \mathrm{~m}^{3}$ a.e. per $\mathrm{m}^{2}$ ingekochte warmte gebruikt. De dekking bij wkk en bij inkoop warmte kwam in 2018 dus overeen.

\section{Achtergronden}

De hoeveelheid warmte die per $\mathrm{m}^{2}$ wordt ingekocht en het gebruik van warmte vanuit de wkk's van de tuinders per $\mathrm{m}^{2}$ ligt dus op een substantieel hoger niveau dan bij duurzame warmte (paragraaf 3.4). Dit komt vooral door een grotere capaciteit van de warmtebron per $\mathrm{m}^{2}$ kas en contractafspraken. Bovendien wordt op het areaal met inkoop warmte in beperkte mate gebruik gemaakt van wkk's in vergelijking met het landelijke beeld en is de inkoop warmte vaak gecombineerd met de levering van externe $\mathrm{CO}_{2}$. 


\section{$5 \quad$ Reflectie}

\section{Inleiding}

In de voorgaande hoofdstukken zijn de ontwikkelingen van de energie-indicatoren van de glastuinbouw en van de achterliggende oorzaken tot en met 2018 beschreven. De belangrijkste indicator - vanuit beleidsoogpunt - is de $\mathrm{CO}_{2}$-emissie. In deze reflectie is vanuit dit perspectief gekeken naar de stand van zaken en de ontwikkeling.

\section{$\mathrm{CO}_{2}$-emissiereductie heeft extra impuls nodig}

In hoofdstuk 2 is gebleken dat de $\mathrm{CO}_{2}$-emissie sinds 2014 is gestabiliseerd. De $\mathrm{CO}_{2}$-emissie nam toe door een groeiend energiegebruik per $\mathrm{m}^{2}$ en door meer verkoop elektriciteit. Dit werd gecompenseerd door afname van het areaal, toename van het gebruik van duurzame energie en toename inkoop elektriciteit. In de eerdere periode 2010-2014 lieten de eerste twee factoren een tegenovergestelde ontwikkeling zien met als gevolg dat de $\mathrm{CO}_{2}$-emissie in deze periode substantieel daalde.

\section{Energiegebruik per $\mathrm{m}^{2}$ neemt toe na eerdere daling}

De ontwikkeling van het energiegebruik per $\mathrm{m}^{2}$ wordt bepaald door de factoren intensivering, extensivering en energiebesparing. In een separaat en eerder uitgevoerd onderzoek konden, door extra informatieverzameling, de effecten van deze factoren op de $\mathrm{CO}_{2}$-emissie worden gekwantificeerd over de periode 2010-2015 (Van der Velden en Smit, 2017). In deze periode brachten deze drie factoren per saldo een reductie van de $\mathrm{CO}_{2}$-emissie van 0,41 Mton met zich mee. Door intensivering nam de $\mathrm{CO}_{2}$-emissie met 0,28 tot 0,40 Mton toe, door extensivering daalde deze met 0,13 Mton en ook door energiebesparing trad een daling op van met 0,5 tot 0,7 Mton.

Over de periode na 2015 is een dergelijk onderzoek niet uitgevoerd. Over de periode 2014-2018 bracht het totaaleffect van het energiegebruik per $\mathrm{m}^{2}$ ofwel het saldo van de factoren intensivering, extensivering en energiebesparing een toename van de $\mathrm{CO}_{2}$-emissie van 0,35 Mton met zich mee (paragraaf 2.5). Dit betekent dat de intensivering een substantieel groter effect had dan het totaaleffect van extensivering en energiebesparing. Dit betekent echter niet dat er geen energiebesparing is gerealiseerd, het kan alleen met de beschikbare informatie niet als afzonderlijke factor worden gekwantificeerd.

\section{Economische groei verandert de teelt}

Een belangrijke kracht achter de ontwikkelingen van de intensivering is economische groei. In de periode voor 2014 was er geen groei, maar kromp in Nederland - en in de belangrijkste exportbestemmingen van de glastuinbouw - de economie. Vanaf 2014 is er weer groei, het dal van de economische crisis ligt al enige tijd achter ons. Dit uit zich ook in verbeterde bedrijfsresultaten (rentabiliteit en inkomen) in de glastuinbouw (www.agrimatie.nl). Voor de nabije toekomst wordt door het CPB ook groei verwacht. Dit heeft invloed op het toekomstvertrouwen en de (internationale) vraag naar glastuinbouwproducten. Producten met een hoge kwaliteit worden aangeboden omdat de markt hiernaar vraagt; dit brengt intensivering met zich mee, onder meer door productie in de winterperiode met belichting en hierdoor neemt het energiegebruik per $\mathrm{m}^{2}$ toe. De marktvraag leidt ook tot veranderingen in het areaal van de geteelde gewassen. Ook dit structuureffect zal van invloed zijn geweest op het energiegebruik per $\mathrm{m}^{2}$.

\section{Doel 2020, prognose 2020 en tussenstand}

Met de ontwikkelingen en achtergronden in beeld rijst vervolgens de vraag wat de recente ontwikkelingen betekenen voor de realisatie van het $\mathrm{CO}_{2}$-doel voor 2020 (4,6 Mton). In 2016 heeft Wageningen Economic Research op basis van de toen beschikbare inzichten een prognose gemaakt van de $\mathrm{CO}_{2}$-emissie van de glastuinbouw in 2020 (Van der Velden en Smit, 2016). In de prognose is uitgegaan van de afzonderlijke invloedsfactoren op de $\mathrm{CO}_{2}$-emissie. Voor het areaal werd een verdere krimp verondersteld, voor verkoop elektriciteit een afname, voor het gebruik van duurzame warmte 
een toename, voor inkoop warmte een lichte afname en voor inkoop elektriciteit een toename. Tot slot werd door het energiegebruik per $\mathrm{m}^{2}$ per saldo een afname van de $\mathrm{CO}_{2}$-emissie verondersteld.

Ontwikkelingen kunnen in werkelijkheid anders uitpakken. Vooral op korte termijn kunnen incidentele ontwikkelingen van invloed zijn. In paragraaf 2.5 is gebleken dat in de periode 2014-2018 het areaal, het gebruik van duurzame warmte en inkoop elektriciteit zich hebben ontwikkeld overeenkomstig de richting in de prognose. Het areaal daalde, het gebruik van duurzame energie en de inkoop van elektriciteit namen toe. Inkoop warmte is vrijwel gelijk gebleven terwijl in de prognose werd uitgegaan van afname. Verkoop van elektriciteit en het energiegebruik per $\mathrm{m}^{2}$ lieten een toename zien en dat is tegengesteld aan de prognose. Per saldo week de werkelijke ontwikkeling af van de prognose.

\section{Actuele verwachting nabije toekomst}

Voor de invloedsfactoren areaalmutatie, inkoop elektriciteit, gebruik duurzame energie en het energiegebruik per $\mathrm{m}^{2}$, is voor 2020 uitgegaan van extrapolatie van de ontwikkeling in de periode 2014-2018. Verwacht wordt dat bij deze factoren de ontwikkelingen zich zullen voortzetten. Voor de factoren verkoop elektriciteit en inkoop warmte is verondersteld dat deze onveranderd blijven in de periode 2018-2020. De verkoop elektriciteit wordt begrensd door de warmtevraag en voor inkoop warmte wordt voor 2020 geen groei voorzien.

Met deze veronderstellingen zal de $\mathrm{CO}_{2}$-emissie in de periode 2018-2020 weinig veranderen. De $\mathrm{CO}_{2}$ emissie in 2020 zou dan ruim boven het doel voor 2020 uitkomen. Ondanks de onzekerheden van een dergelijke quick scan - en rekening houdend met mogelijke afwijkende incidentele ontwikkelingen op deze hele korte termijn - is de verwachting dat het $\mathrm{CO}_{2}$-doel voor de glastuinbouw 2020 niet gerealiseerd zal worden.

\section{Energie-efficiëntie ook stabiel}

De ontwikkeling van de energie-efficiëntie is net als die van de $\mathrm{CO}_{2}$-emissie stabiel. $\mathrm{Bij}$ de $\mathrm{CO}_{2}$-emissie is vanaf 2014 stabilisatie opgetreden, bij de energie-efficiëntie is dit al vanaf 2010 het geval. Dit komt doordat de fysieke productie minder toeneemt en het primair brandstofverbruik licht stijgt. Het eerste komt vooral doordat een hogere waarde per eenheid product wordt nagestreefd met productieplanning en kwaliteit. Het tweede komt door marktvraaggerichte productie in de winterperiode met belichting, waardoor de energievraag toeneemt. Daarnaast wordt er sinds 2010 minder elektriciteit verkocht vanuit de aardgas wkk's.

\section{Warmtedekking duurzame energie verhogen is van groot belang}

Het aandeel van het areaal met duurzame energie in het totaal areaal glastuinbouw steeg de afgelopen 10 jaar van 3 naar 17\% en het aandeel duurzaam in het energiegebruik van 1 naar $7 \%$. Hiermee samenhangend is de warmtedekking van duurzame warmte gedaald en zal de groei van het gebruik van duurzame energie op termijn tegen grenzen aanlopen. In de hoofdstukken 3 en 4 is gebleken dat de gerealiseerde gemiddelde warmtedekking bij duurzame warmte ( $15 \mathrm{~m}^{3}$ a.e. per $\left.\mathrm{m}^{2}\right)$ lager is dan bij inkoop warmte $\left(23 \mathrm{~m}^{3}\right.$ a.e. per $\left.\mathrm{m}^{2}\right)$ en bij aardgas-wkk's ( $22 \mathrm{~m}^{3}$ a.e. per $\mathrm{m}^{2}$ ). Een hogere dekking bij duurzame warmte is nodig voor de verdere reductie van de $\mathrm{CO}_{2}$-emissie op sectorniveau, die wordt nagestreefd in doelen en ambities. Ter illustratie: bij een hogere gemiddelde warmtedekking van $10 \mathrm{~m}^{3}$ a.e. per $\mathrm{m}^{2}$ op het gehele glastuinbouwareaal bedraagt de extra reductie van de $\mathrm{CO}_{2}$-emissie van de glastuinbouw 0,9 Mton.

Voor het realiseren van een hogere dekking is een grotere warmtecapaciteit per $\mathrm{m}^{2}$ kas nodig. Echter, hoe hoger de dekking, hoe lager het bedrijfseconomisch rendement van de projecten. De warmtebron wordt immers niet continue gebruikt op de maximale capaciteit. De dekking kan ook hoger worden door de combinatie van meerdere warmtebronnen op hetzelfde areaal. Bij deze geïntegreerde inzet van meerdere bronnen zal de gebruiksduur van de tweede bron echter korter zijn, hetgeen bedrijfseconomisch ongunstig is.

\section{Paradox van stimuleringsregelingen}

Bijna alle projecten voor duurzame energievoorziening in de glastuinbouw komen tot stand met ondersteuning vanuit de overheid. Het overgrote deel van de projecten maakt gebruik van de SDEregeling. De basisgedachte van deze regeling is dat de onrendabele top van de exploitatie 
compensatie krijgt. Hierbij wordt uitgegaan van de beste kosteneffectiviteit van de subsidie uitgedrukt in $€$ per $\mathrm{kg}$ vermeden $\mathrm{CO}_{2}$-emissie. Projecten die gerealiseerd worden, streven een lange gebruiksduur op jaarbasis na, waardoor deze bedrijfseconomisch en op kosteneffectiviteit beter scoren. Door de warmtebron in te zetten op een groter areaal is de warmtecapaciteit per $\mathrm{m}^{2}$ kas kleiner, de gebruiksduur langer en de warmtedekking lager. De kosteneffectiviteit per vermeden $\mathrm{kg} \mathrm{CO}_{2}$-emissie is dan beter en deze projecten komen eerder in aanmerking voor subsidie. Ook vanuit projectrisico- en financieringsoogpunt wordt er naar gestreefd om meer bedrijven en areaal te betrekken bij een project. Ook hierdoor is de warmtecapaciteit per $\mathrm{m}^{2}$ kleiner, de gebruiksduur langer en de warmtedekking lager. Daarnaast is de geïntegreerde inzet van meerdere bronnen geen element van de SDE-regeling. De opties worden separaat beoordeeld. Het voorgaande staat in contrast met het streven van de glastuinbouw en de overheid om de $\mathrm{CO}_{2}$-emissie sterk te reduceren, want hiervoor is juist een hoge dekking nodig.

\section{Energie- en $\mathrm{CO}_{2}$-voorzieningen in dienst van de energietransitie}

Door de glastuinbouw wordt op grote schaal gebruik gemaakt van aardgas-wkk's. Deze wkk's zijn de grootste veroorzaker van de $\mathrm{CO}_{2}$-emissie van de glastuinbouw. Een simpele redenering zou zijn het wkk gebruik te verminderen en zo $\mathrm{CO}_{2}$-emissie te verlagen. Echter de wkk draagt substantieel bij aan reductie van de $\mathrm{CO}_{2}$-emissie op nationaal niveau. Door wkk-gebruik in de Nederlandse glastuinbouw is de $\mathrm{CO}_{2}$-emissie op nationaal niveau lager, omdat in tegenstelling tot energiecentrales de warmtebenutting bijna volledig is. In de glastuinbouw zijn aardgas-wkk's ook de belangrijkste bron voor de warmte-, elektriciteits- en $\mathrm{CO}_{2}$-voorziening. Bij duurzame energiebronnen komt geen $\mathrm{CO}_{2}$ beschikbaar voor het gewas. De $\mathrm{CO}_{2}$-voorziening vanuit de wkk maakt het mogelijk om duurzame warmte te gebruiken met een beperkte warmtedekking. Hiernaast spelen wkk's een essentiële rol in de voorziening van de toenemende de elektriciteitsvraag door vooral groeilicht in de glastuinbouw en bij de elektrificering van het energiegebruik in haar omgeving. Als wkk wordt vervangen zijn er andere bronnen voor de $\mathrm{CO}_{2}$-voorziening en de elektriciteitsvoorziening nodig. Inkoop van elektriciteit en $\mathrm{CO}_{2}$ brengt voor de glastuinbouw geen $\mathrm{CO}_{2}$-emissie met zich mee. Voor de extra inkoop van elektriciteit is extra infrastructuur nodig en dat is in de praktijk nu vaak al een knelpunt. Voor de $\mathrm{CO}_{2}$-voorziening is ook infrastructuur nodig en zullen extra externe bronnen moeten worden ontsloten. Daarbij speelt ook de wijze van beoordeling van de onrendabele top in stimuleringsmaatregelen op basis van de kosteneffectiviteit een belangrijke rol.

\section{Kosten}

$\mathrm{Bij}$ de keuze door glastuinbouwbedrijven voor het gebruik van warmte zonder $\mathrm{CO}_{2}$-emissie (duurzame warmte en inkoop warmte) ter vervanging van aardgas wkk spelen naast reductie van de $\mathrm{CO}_{2}$-emissie, de kostenaspecten een belangrijke rol. Als warmtevoorzieningen zonder $\mathrm{CO}_{2}$-emissie hogere kosten met zich meebrengen dan de bestaande voorziening met de wkk, dan is dit een rem op het gebruik van warmtevoorzieningen zonder $\mathrm{CO}_{2}$-emissie. Het kostenverschil wordt bepaald door de spark spread voor de wkk, de kosten voor de duurzame energiebron of inkoop warmte, de kosten voor de externe $\mathrm{CO}_{2}$ en inkoop elektriciteit en de waardering van het geteelde product. Hierbij kunnen stimuleringsmaatregelen en tariefstructuren voor energie (commodity en heffingen) mede bepalend zijn. Een dergelijke transitie kunnen glastuinbouwbedrijven niet individueel realiseren. Intensieve samenwerking onderling en met partners buiten de sector is hiervoor noodzakelijk. 


\section{Conclusies}

$\mathrm{CO}_{2}$-emissie

- De totale $\mathrm{CO}_{2}$-emissie van de Nederlandse glastuinbouw bedroeg in 2018 5,7 Mton. Dat is 1,1 Mton boven het doel voor 2020 (4,6 Mton). Over de periode 2014-2018 was de totale $\mathrm{CO}_{2}$-emissie stabiel.

- De totale $\mathrm{CO}_{2}$-emissie lag in 2018 16\% onder het niveau van 1990. De $\mathrm{CO}_{2}$-emissie van de teelt (exclusief verkoop elektriciteit) lag 39\% onder het niveau van 1990. In Nederland als geheel was dit $1 \%$ lager dan in 1990. De glastuinbouw ligt bij het terugdringen van de $\mathrm{CO}_{2}$-emissie voor op de nationale ontwikkeling.

- De totale $\mathrm{CO}_{2}$-emissie na temperatuurcorrectie bleef in de periode 2014-2018 vrijwel gelijk (-0,1 Mton) terwijl in de periode 2010-2014 een reductie van 1,9 Mton werd gerealiseerd.

- In de periode 2014-2018 brachten een groeiend energiegebruik per $\mathrm{m}^{2}$ (+0,35 Mton) en meer verkoop elektriciteit $\left(+0,10 \mathrm{Mton}\right.$ ) een toename van de $\mathrm{CO}_{2}$-emissie met zich mee. Dit werd gecompenseerd door krimp van het areaal (-0,24 Mton), toename van het gebruik van duurzame energie (-0,20 Mton) en meer inkoop elektriciteit (-0,11 Mton).

- Het toegenomen energiegebruik per $\mathrm{m}^{2}$ bracht in de periode 2014-2018 een toename van de $\mathrm{CO}_{2}-$ emissie met zich mee. Het effect van intensivering was daardoor groter dan het totaaleffect van extensivering en energiebesparing.

- Het aandeel van aardgas in de energievoorziening van de glastuinbouw daalde in de periode 20102018 van $88 \%$ naar $81 \%$. De energievoorziening van de glastuinbouw bleef daarmee afhankelijk van aardgas, maar de eerste stappen om minder afhankelijk te worden zijn gezet.

- Op basis van de ontwikkelingen in de achterliggende jaren en een quick scan van de actuele inzichten in de nabije toekomst wordt verwacht dat ook tot en met 2020 de $\mathrm{CO}_{2}$-emissie niet veel zal wijzigen en dat de doelstelling voor 2020 niet wordt gehaald.

\section{Energie-efficiëntie}

- De energie-efficiëntie is in 2018 gelijk gebleven en bedroeg 42\% ten opzichte van 1990.

- Dit kwam doordat het primair brandstofverbruik per $\mathrm{m}^{2}$ zich in dezelfde mate ontwikkelde als de fysieke productie per $\mathrm{m}^{2}$. Beiden name af met ruim $1 \%$.

- De daling van de fysieke productie in 2018 hangt waarschijnlijk samen met de warme zomer. De daling van het primair brandstofverbruik in 2018 komt vooral door de toename van de elektriciteitsverkoop vanuit aardgas wkk's.

- Over een langere periode bezien verbeterde de energie-efficiëntie nauwelijks. Vanaf 2010 compenseerden de toename van de fysieke productie en de toename van het primair brandstofverbruik elkaar en beiden lagen op een relatief laag niveau. De ontwikkeling van de fysieke productie werd geremd doordat een hogere waarde per eenheid product werd nagestreefd. Het primair brandstofverbruik steeg door minder verkoop elektriciteit en toename van de elektriciteitsconsumptie door intensivering vooral in de vorm van belichting.

\section{Duurzame energie}

- Het aandeel duurzame energie groeide in 2018 met 0,9 procentpunt naar 7,3\% en het absolute gebruik groeide met 0,7 PJ naar 7,4 PJ.

- In 2018 was aardwarmte met $48 \%$ de meest toegepaste duurzame energiebron, op afstand gevolgd door inkoop duurzame elektriciteit (20\%), zonne-energie (11\%), biobrandstoffen (10\%) en de inkoop van duurzame warmte $(10 \%)$. Inkoop van duurzaam gas $(<1 \%)$ bleef ook in 2018 beperkt.

- In 2018 steeg zowel het aandeel als het absolute gebruik van duurzame energie minder hard dan in 2017. De groei zat bij aardwarmte en inkoop duurzame warmte, inkoop van duurzame elektriciteit nam af.

- Het aandeel duurzame energie was in 2017 en 2018 vrijwel gelijk aan het landelijke aandeel.

- Het gebruik van duurzame energie bestond voor $80 \%$ uit warmte en $20 \%$ uit elektriciteit. Duurzame warmte werd voor $87 \%$ zelf geproduceerd en duurzame elektriciteit voor $96 \%$ ingekocht.

- Het areaal met duurzame energie (exclusief inkoop uit openbare netten), nam in 2018 toe naar bijna 1.500 ha. Dit is $17 \%$ van het totaal areaal. 
- Duurzame energie wordt vooral toegepast op de grotere bedrijven en verminderde de $\mathrm{CO}_{2}$-emissie van de glastuinbouw in 2018 met 0,32 Mton.

- Het gebruik van externe $\mathrm{CO}_{2}$ groeide in 2018 met bijna 10\% naar 0,64 Mton.

\section{Energiekosten en energiegebruik}

- De kosten voor inkoop van energie stegen in 2018 harder dan de opbrengsten voor de verkoop waardoor de netto-energiekosten $\left(€ / \mathrm{m}^{2}\right)$ toenamen.

- Het energiegebruik per $\mathrm{m}^{2}$ kas nam in de periode 2014-2018 toe met 7\%. De groei van de elektriciteitsconsumptie (+22\%) was groter die dan de warmteconsumptie $(+3 \%)$.

- Het totaal energiegebruik nam na groei in de jaren 2014-2017 in 2018 af tot 100,5 PJ en bestond voor circa $74 \%$ uit warmte en voor circa $26 \%$ uit elektriciteit. In 2010 was dat $90 \%$ en $10 \%$.

Warmtekrachtkoppeling, elektriciteitsbalans en inkoop warmte

- In de jaren 2015-2018 was het totaal vermogen van de wkk's met ruim 2.400 MWe wat kleiner dan in de periode 2012-2014. De kwam vooral door krimp van het areaal. In 2018 had circa 63\% van het areaal wkk in gebruik.

- De gemiddelde gebruiksduur lag in 2018 op bijna 3.900 uur, dit is bijna $20 \%$ meer dan in 2016. Dit komt door een verbeterde spark spread, zowel in 2017 en 2018.

- De elektriciteitsproductie met wkk bedroeg in 2018 ruim 9 miljard kWh en hiermee werd bijna 8\% van de nationale elektriciteitsconsumptie voorzien. De productie lag 1,2 miljard kWh hoger dan in 2016. De verkoop bedroeg 5,6 miljard kWh.

- Door de aardgas-wkk's lag in 2018 de $\mathrm{CO}_{2}$-emissie van de glastuinbouw 2,6 Mton hoger, van elektriciteitscentrales 4,2 Mton lager en werd op nationaal niveau 1,6 Mton $\mathrm{CO}_{2}$-emissie vermeden.

- Na een toename in de periode 2010-2017 stabiliseerde de inkoop van elektriciteit in 2018 op 2,8 miljard kWh.

- De productie en verkoop van elektriciteit met wkk nam zowel in 2017 en 2018 vooral toe in de winterperiode en wel in maanden met een lagere buitentemperatuur dan het jaar ervoor. Dit betekent dat de extra productie heeft plaatsgevonden met substantiële benutting van de warmte.

- De elektriciteitsconsumptie van de glastuinbouw groeit sinds 2010 en bedroeg in 2018 naar schatting 6,7 miljard kWh. Dit is 5,5\% van de nationale consumptie. De groei komt vooral door de toename van groeilicht.

- De mate waarin in de elektriciteitsvraag werd voorzien met wkk's is gedaald van $62 \%$ in 2014 tot $57 \%$ in 2018 . Dit hangt samen met de intensivering van groeilicht per $\mathrm{m}^{2}$ in combinatie met de grenzen die de warmtevraag stelt aan de benutting van warmte uit de wkk's.

- Ingekochte warmte (exclusief duurzame warmte) nam in 2018 met 0,3 PJ af naar 3,4 PJ. De daling komt door de lagere warmtevraag en de grotere fractie duurzaam in de geleverde warmte.

- Warmte-inkoop reduceerde de $\mathrm{CO}_{2}$-emissie van de glastuinbouw in 2018 met 0,14 Mton.

\section{Warmtedekking}

- De warmtedekking $\left(\mathrm{m}^{3}\right.$ a.e. $\left./ \mathrm{m}^{2}\right)$ is bij duurzame warmte kleiner dan bij inkoop warmte of aardgaswkk's en vertoont ook een dalende trend, waardoor het gebruik van duurzame warmte op termijn tegen grenzen aan kan lopen.

- Voor reductie van het $\mathrm{CO}_{2}$-doel op sectorniveau is het van belang dat er hoge dekkingen worden gerealiseerd bij zowel duurzame warmte als bij inkoop warmte. Dit kan door een grotere warmtecapaciteit per $\mathrm{m}^{2}$, maar ook door geïntegreerde inzet van meerdere bronnen.

- Voor het realiseren van een hogere warmtedekking zijn bij duurzame warmte en inkoop warmte overheidsondersteuning vanuit de SDE op basis van kosteneffectiviteit, risicospreiding bij de projecten en beschikbaarheid van externe $\mathrm{CO}_{2}$-aandachtspunten.

- De geïntegreerde inzet van meerdere bronnen is geen element van de SDE-regeling; de bronnen worden separaat beoordeeld. 


\section{Literatuur en websites}

Brief van de Staatssecretaris van Economische Zaken, de heer Martijn van Dam, aan de voorzitter van de Tweede Kamer betreffende Evaluatie $\mathrm{CO}_{2}$-suring in de glastuinbouw, dd. 6 juli 2017.

Convenant $\mathrm{CO}_{2}$ emissieruimte binnen het $\mathrm{CO}_{2}$ sectorsysteem glastuinbouw voor de periode 20132020. 2011.

Hernieuwbare energie in Nederland t/m 2018, CBS, Den Haag, Statline versie 27 juni 2019.

Klimaatakkoord, Den Haag 28 juni 2019; paragraaf 4.6 Glastuinbouw.

Meerjarenafspraak Energietransitie Glastuinbouw 2014-2020, Den Haag, 2014.

Smit, P.X. en N.J.A. van der Velden, Kompas op 2030; Verduurzamingsrichtingen energievoorziening Westlandse glastuinbouw. Rapport 2018-011. Wageningen Economic Research, 2018.

Smit, P.X. en N.J.A. van der Velden, Oostlandse glastuinbouw zet koers naar 2030; Verduurzamingsrichtingen energievoorziening van de Oostlandse glastuinbouw. Rapport 2019-066. Wageningen Economic Research, 2019

Velden, N. van der en P. Smit, Groei elektriciteitsconsumptie glastuinbouw; Hoe verder?. Rapport 2013-022. LEI Wageningen UR, 2013.

Velden, N. van der en P. Smit, Prognose $\mathrm{CO}_{2}$-emissie glastuinbouw 2020. Rapport 2016-067. Wageningen Economic Research, 2016.

Velden, N. van der en P. Smit, Effect intensivering, extensivering en energiebesparing op $\mathrm{CO}_{2}$-emissie Nederlandse glastuinbouw. Rapport 2017-060. Wageningen Economic Research, 2017

Velden, N.J.A. van der, P.X. Smit en J.S. Buurma, Prognoses $\mathrm{CO}_{2}$-emissie glastuinbouw 2030. Rapport 2018-056. Wageningen Economic Research, 2018.

Velden, N.J.A. van der en P.X. Smit, Prognoses $\mathrm{CO}_{2}$-behoefte glastuinbouw 2030. Rapport 2019-074. Wageningen Economic Research, 2019a.

Velden, N.J.A. van der en P.X. Smit, Conceptueel ontwerp Regionale Energiemonitor Glastuinbouw. Rapport 2019-061 Wageningen Economic Research, 2019b.

Velden, N.J.A. van der en P.X. Smit, Nulmeting Regionale Energiemonitor Glastuinbouw Greenport West-Holland. Rapport 2019-060. Wageningen Economic Research, 2019c.

Velden, N.J.A. van der en P.X. Smit, Protocol Energiemonitor Glastuinbouw; Versie tot en met 2018. Nota 2019-111a. Wageningen Economic Research, 2019d.

WKK Barometer, Marktpositie wkk voorjaar 2019, BleuTerra Energy Experts, april 2019.

www.agrimatie.nl

www.emissieautoriteit.nl

www.kasalsenergiebron.nl

www.statline.nl 


\section{Bijlage 1 Definities, methode en bronnen}

\section{B1.1 Definities}

Protocol

De definities, methodiek en bronnen zijn vastgelegd in het Protocol Energiemonitor Glastuinbouw (Van der Velden en Smit, 2018) en worden in deze bijlage op hoofdlijnen toegelicht.

\section{Definities van indicatoren}

De energie-efficiëntie is het primair brandstofverbruik per eenheid product van de productieglastuinbouw, uitgedrukt in procenten van het niveau in het basisjaar.

De $\mathrm{CO}_{2}$-emissie wordt uitgedrukt in Mton per jaar en wordt bepaald volgens de IPCC-methode en heeft betrekking op de gehele glastuinbouwsector. Onderscheid wordt gemaakt naar de totale $\mathrm{CO}_{2}$-emissie van de sector en de $\mathrm{CO}_{2}$-emissie van de teelt (exclusief verkoop elektriciteit uit aardgasgestookte wkk).

Het aandeel duurzame energie is het quotiënt van de gebruikte hoeveelheid duurzame energie en het totale netto-energiegebruik (inkoop minus verkoop) in de gehele glastuinbouw, uitgedrukt in procenten.

De definities van de indicatoren verschillen ten aanzien van het areaal glas en het begrip energie.

\section{Areaal}

De glastuinbouw omvat het areaal productieglastuinbouw en het areaal uitgangsmateriaal (figuur B.1). De productieglastuinbouw bestaat uit de subsectoren groente, bloemen en potplanten. Het uitgangsmateriaal betreft de teelt van zaden en stek en de opkweek van jonge planten.

Uitgangsmateriaal wordt gezien als toelevering (binnen en buiten de glastuinbouw) en niet als primaire productie. Daarom blijft het areaal met uitgangsmateriaal buiten beschouwing bij de energieefficiëntie. De $\mathrm{CO}_{2}$-emissie heeft betrekking op de gehele glastuinbouw, inclusief het areaal uitgangsmateriaal.

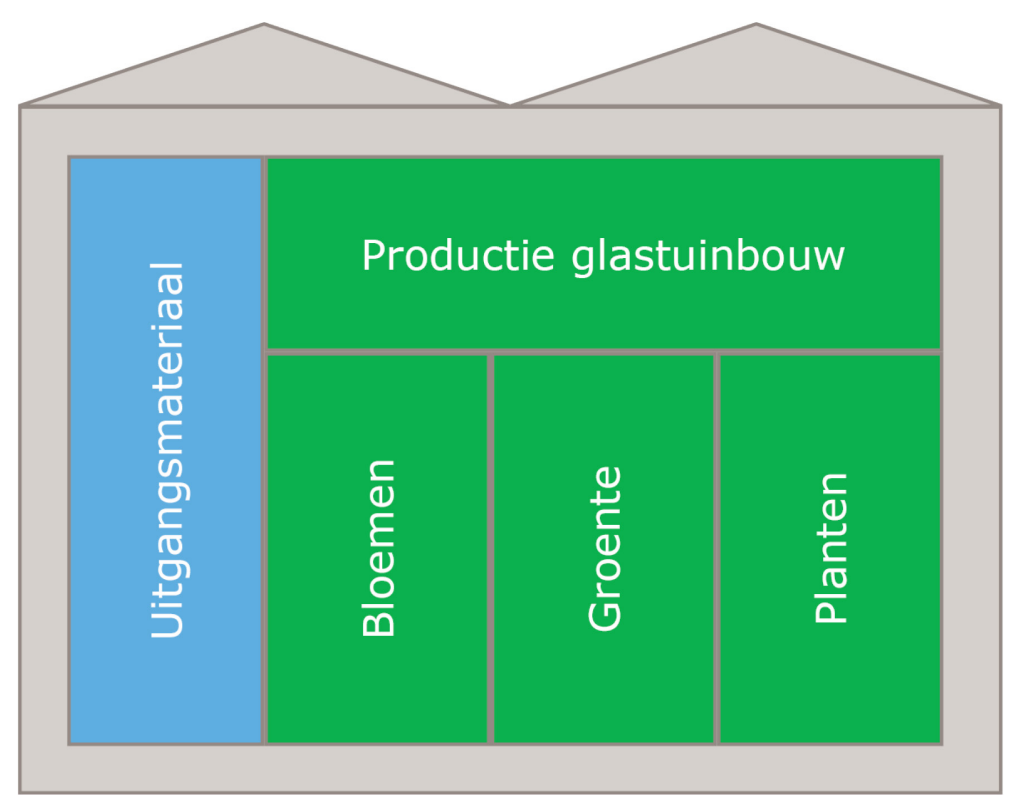

Figuur B.1 Schematische weergave areaal glastuinbouw en productieglastuinbouw 


\section{Energie}

Het energiegebruik in de glastuinbouw omvat meerdere soorten (figuur B.2). Aardgas, overig fossiel, warmte en elektriciteit worden ingekocht en elektriciteit en warmte verkocht. Duurzame energie wordt ingekocht, geproduceerd en verkocht. Dit alles is op verschillende wijzen te sommeren.

Sommatie van de afzonderlijke energiesoorten op basis van energie-inhoud resulteert in het kengetal totaal energiegebruik. De verkoop van energie wordt hierbij in mindering gebracht.

Voor het primair brandstofverbruik wordt de hoeveelheid fossiele brandstof bepaald die nodig is voor de productie van de afzonderlijke energiesoorten. Aardgas en overige fossiele brandstoffen zijn primaire brandstoffen. De inkoop van elektriciteit wordt herleid tot de hoeveelheid brandstof die daarvoor nodig is in een gemiddelde Nederlandse elektriciteitscentrale zonder warmtelevering. Voor de verkoop van elektriciteit geldt hetzelfde, maar dit wordt in mindering gebracht. De ingekochte warmte komt van elektriciteitscentrales (restwarmte), industrie en van energiebedrijven. Door de gecombineerde productie van elektriciteit en warmte ligt de elektriciteitsproductie lager. Voor de geleverde warmte wordt de extra hoeveelheid brandstof berekend die nodig is om de derving van de elektriciteitsproductie te compenseren.

De $\mathrm{CO}_{2}$-emissie wordt bepaald op basis van de IPCC-methode. Hierbij wordt alleen de werkelijk verstookte fossiele brandstof op glastuinbouwbedrijven in beschouwing genomen. Onderscheid wordt gemaakt naar de totale $\mathrm{CO}_{2}$-emissie en de $\mathrm{CO}_{2}$-emissie van de teelt. De totale $\mathrm{CO}_{2}$-emissie heeft betrekking op alle fossiele brandstoffen, inclusief de productie van elektriciteit op de glastuinbouwbedrijven. De $\mathrm{CO}_{2}$-emissie van de teelt is de totale $\mathrm{CO}_{2}$-emissie, verminderd met de emissie die gerelateerd is aan door de glastuinbouw verkochte elektriciteit, geproduceerd met aardgasgestookte wkk.

Het primair brandstofverbruik is de grondslag voor de energie-efficiëntie. De $\mathrm{CO}_{2}$-emissie wordt bepaald op basis van het werkelijke gebruik van fossiele brandstoffen (IPCC-methode).

Het totale energiegebruik wordt gebruikt voor het bepalen van het aandeel duurzame energie. Netto wil zeggen inkoop minus verkoop.

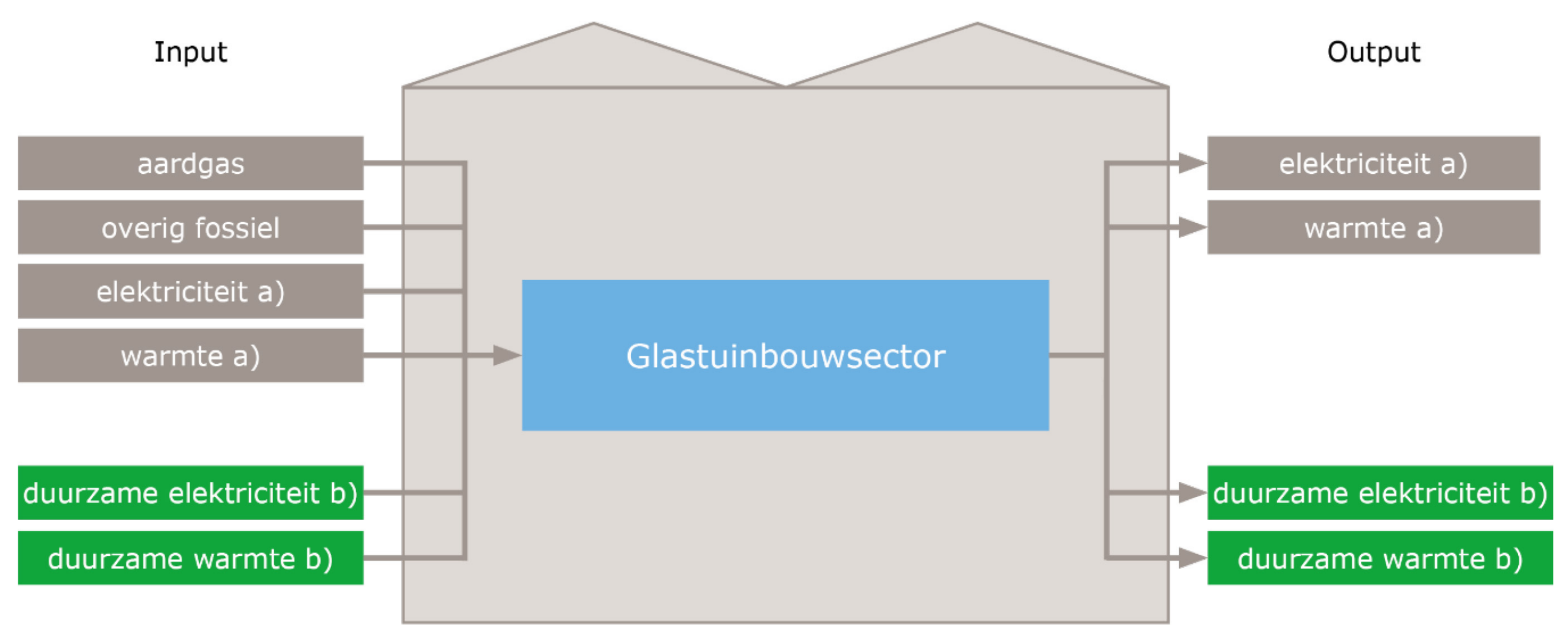

Figuur B.2 Energie-input en -output van de glastuinbouwsector

a) Fossiele bron.

b) Hernieuwbare of duurzame bron.

\section{Duurzame energie}

Duurzame energie omvat energie uit zon, wind, waterkracht, aardwarmte en biobrandstof via een hernieuwbaar proces. Hernieuwbaar betekent dat er geen fossiele brandstof wordt gebruikt en er netto geen $\mathrm{CO}_{2}$-emissie ontstaat. Het aandeel duurzame energie heeft betrekking op het gebruik in de glastuinbouw. Duurzaam geproduceerde energie voor gebruik buiten de sector telt niet mee. 
Voorbeelden hiervan zijn op biobrandstof gestookte wkk's, waarvan de geproduceerde elektriciteit (deels) wordt verkocht buiten de sector of aardwarmte dat wordt verkocht buiten de sector. Verkoop van duurzame energie binnen de sector telt wel mee, evenals ingekochte duurzame elektriciteit en duurzame warmte van buiten de sector.

Bij het bepalen van het totale energiegebruik in de glastuinbouw op basis van energie-inhoud telt de duurzame energie wel mee. Dit is niet het geval bij het bepalen van het primair brandstofverbruik en de $\mathrm{CO}_{2}$-emissie.

\section{Temperatuurcorrectie}

Het energiegebruik verschilt van jaar tot jaar, mede door verschillen in buitentemperatuur. Het primair brandstofverbruik, en dus ook de energie-efficiëntie, wordt hiervoor gecorrigeerd. Bij het totale energiegebruik, het aandeel duurzame energie en de $\mathrm{CO}_{2}$-emissie vindt geen temperatuurcorrectie plaats.

\section{B1.2 Methode en bronnen}

Voor het kwantificeren van de indicatoren moeten de totale energie-input en -output van de glastuinbouw en de productieglastuinbouw opgesplitst naar afzonderlijke energiesoorten worden vastgesteld (figuur B.2). Voor de energie-efficiëntie betreft dit ook de fysieke productie. Daarnaast is informatie nodig voor het opstellen van de elektriciteitsbalans.

De belangrijkste informatiebronnen zijn:

- energieregistraties van het Milieu Project Sierteelt (MPS);

- energieregistraties van Greelinqdata;

- energieregistraties van groepen tuinders en adviseurs;

- energieregistraties van groentebedrijven van het Bedrijveninformatienet van het Wageningen Economic Research;

- inkoop warmte van de leveranciers;

- elektrisch vermogen van en elektriciteitsproductie door wkk's van energiebedrijven en tuinders vanuit de inventarisatie door BlueTerra;

- gebruiksduur van wkk van tuinders op basis van informatie van energiebedrijven, groepen tuinders en het Bedrijveninformatienet van Wageningen Economic Research;

- veilingomzetten bloemen en planten van de FloraHolland en Plantion;

- prijsinformatie bloemen en planten van FloraHolland;

- fysieke productie vruchtgroenten van het Bedrijveninformatienet van Wageningen Economic Research, accountants, telersverenigingen, groepen tuinders en adviseurs;

- areaalgegevens en informatie over het gebruik van wkk door tuinders uit de Landbouwtelling, gepubliceerd door het Centraal Bureau voor de Statistiek (CBS);

- areaalgegevens belichting vruchtgroenten van adviseurs en telersverenigingen;

- verkoopinformatie duurzame elektriciteit van energiebedrijven;

- informatie over aardwarmteproductie van Dutch Association Geothermal Operators (DAGO);

- leveranciers van installaties en adviseurs.

\section{Energie-input en -output}

Figuur B.2 geeft de energie-input en -output van de glastuinbouw schematisch weer. MPS, Greelinqdata en andere bronnen bieden informatie over het energiegebruik per energiesoort in de subsectoren groente, bloemen, potplanten en uitgangsmateriaal. De bedrijfsgegevens van deze bronnen zijn ingedeeld naar gewas(groep) conform de Landbouwtelling van het CBS. Met behulp van de areaalgegevens per gewas(groep) van de Landbouwtelling is de energie-informatie per gewas(groep) geaggregeerd naar sectorniveau. Daarnaast is informatie beschikbaar over de warmteinkoop door de glastuinbouw. 


\section{Wkk en elektriciteitsbalans}

De glastuinbouw produceert op grote schaal elektriciteit met wkk. De elektriciteitsproductie van deze installaties is het product van het totaal elektrisch vermogen in de glastuinbouw en de gemiddelde gebruiksduur.

Voor het in kaart brengen van een elektriciteitsbalans zijn de inkoop, verkoop en productie gekwantificeerd, waarna de elektriciteitsconsumptie is berekend. Bij dit laatste dient opgemerkt te worden dat de consumptie de sluitpost is waarin alle eventuele fouten bij het bepalen van de inkoop, verkoop en productie doorwerken. De informatie over de consumptie moet daardoor gezien worden als een globale indicatie.

\section{Inventarisatie duurzame energie}

Statistieken over het gebruik van duurzame energiebronnen zijn nog nauwelijks beschikbaar. Duurzame energie is in kaart gebracht middels een inventarisatie van de projecten. Voor inkoop duurzame elektriciteit is informatie verzameld over de verkoop aan de glastuinbouw bij energiebedrijven. Voor aardwarmte is gebruik gemaakt van informatie van DAGO.

\section{Fysieke productie}

De glastuinbouw brengt vele producten voort. De fysieke productie wordt uitgedrukt in verschillende eenheden: tomaten en paprika per kg, komkommers per stuk, bloemen per stuk of per bos en potplanten per stuk. Sommatie van deze eenheden vindt indirect plaats. Hierbij wordt uitgegaan van de totale omzet aan glastuinbouwproducten per jaar. Omzetverschillen tussen jaren hangen samen met mutaties in prijs en in fysieke productie. De fysieke productie wordt bepaald door de jaaromzet te corrigeren voor de gemiddelde prijsmutatie van de glastuinbouwproducten.

Bij de groente is beperkte informatie beschikbaar over jaaromzet en prijsmutaties. Daarom is voor deze subsector informatie over de ontwikkeling van de fysieke productie verzameld van de belangrijkste gewassen (tomaat, paprika en komkommer). Deze gewassen omvatten het overgrote deel van het areaal groente. 


\section{Bijlage 2 Kenmerken en energie-indicatoren glastuinbouw}

\begin{tabular}{|c|c|c|c|c|c|c|c|c|c|c|c|c|c|}
\hline Grootheid & Eenheid & 1980 & 1990 & 2000 & 2005 & 2010 & 2012 & 2013 & 2014 & 2015 & 2016 & 2017 & 2018v \\
\hline Areaal glastuinbouw & ha & 8.755 & 9.768 & 10.528 & 10.537 & 10.307 & 9.962 & 9.817 & 9.488 & 9.206 & 9.278 & 9.080 & 8.990 \\
\hline Areaal productieglastuinbouw & ha & 8.527 & 9.368 & 10.036 & 10.028 & 9.757 & 9.405 & 9.235 & 8.876 & 8.609 & 8.635 & 8.430 & 8.380 \\
\hline Buitentemperatuur g) & graaddagen & 3.246 & 2.680 & 2.659 & 2.765 & 3.321 & 2.879 & 3.078 & 2.385 & 2.686 & 2.785 & 2.647 & 2.604 \\
\hline \multirow[t]{2}{*}{ Totaal energie a), c) } & PJ & - & - & 127,5 & 128,1 & 127,1 & 111,6 & 112,9 & 96,0 & 99,4 & 100,4 & 101,1 & 100,5 \\
\hline & $\mathrm{MJ} / \mathrm{m}^{2}$ & - & - & 1.211 & 1.216 & 1.233 & 1.121 & 1.150 & 1.011 & 1.080 & 1.082 & 1.113 & 1.118 \\
\hline \multirow[t]{2}{*}{ Primair brandstof b), d) } & $10^{6} \mathrm{~m}^{3}$ a.e. & 3.488 & 4.195 & 4.276 & 3.860 & 2.565 & 2.517 & 2.544 & 2.393 & 2.395 & 2.442 & 2.424 & 2.376 \\
\hline & $\mathrm{m}^{3}$ a.e. $/ \mathrm{m}^{2}$ & 40,9 & 44,8 & 42,6 & 38,5 & 26,3 & 26,8 & 27,5 & 27,0 & 27,8 & 28,3 & 28,7 & 28,3 \\
\hline Fysieke productie per $\mathrm{m}^{2} \mathrm{~b}$ ) & $\% 1990$ & - & 100 & 114 & 128 & 137 & 139 & 141 & 148 & 147 & 148 & 153 & 151 \\
\hline Energie-efficiëntie b), d) & $\% 1990$ & - & 100 & 84 & 67 & 43 & 43 & 44 & 41 & 42 & 43 & 42 & 42 \\
\hline \multirow[t]{2}{*}{ Fossiel brandstof totaal a), c) } & $10^{6} \mathrm{~m}^{3}$ a.e. & - & 3.808 & 3.710 & 3.596 & 4.502 & 3.847 & 3.847 & 3.163 & 3.213 & 3.172 & 3.214 & 3.200 \\
\hline & $\mathrm{m}^{3}$ a.e. $/ \mathrm{m}^{2}$ & - & 39,0 & 35,2 & 34,1 & 43,7 & 38,6 & 39,2 & 33,3 & 34,9 & 34,2 & 35,4 & 35,6 \\
\hline \multirow[t]{2}{*}{ Fossiel brandstof teelt a), c) } & $10^{6} \mathrm{~m}^{3}$ a.e. & - & 3.808 & 3.670 & 3.398 & 3.227 & 2.802 & 2.804 & 2.369 & 2.419 & 2.422 & 2.401 & 2.348 \\
\hline & $\mathrm{m}^{3}$ a.e. $/ \mathrm{m}^{2}$ & - & 39,0 & 34,9 & 32,3 & 31,3 & 28,1 & 28,6 & 25,0 & 26,3 & 26,1 & 26,4 & 26,1 \\
\hline \multirow[t]{2}{*}{$\mathrm{CO}_{2}$-emissie totaal a), c) } & Mton & - & 6,8 & 6,7 & 6,5 & 8,1 & 6,9 & 6,9 & 5,6 & 5,7 & 5,7 & 5,7 & 5,7 \\
\hline & $\% 1990$ & - & 100 & 97 & 94 & 118 & 100 & 100 & 82 & 84 & 83 & 84 & 84 \\
\hline \multirow[t]{2}{*}{$\mathrm{CO}_{2}$-emissie teelt a), c) } & Mton & - & 6,8 & 6,6 & 6,1 & 5,8 & 5,0 & 5,0 & 4,2 & 4,3 & 4,3 & 4,3 & 4,2 \\
\hline & $\% 1990$ & - & 100 & 96 & 89 & 84 & 73 & 73 & 62 & 63 & 63 & 63 & 61 \\
\hline \multirow[t]{2}{*}{$\mathrm{CO}_{2}$-emissie Nederland f) } & Mton & - & 163,3 & 172,5 & 178,0 & 182,6 & 166,3 & 166,2 & 159,3 & 166,9 & 166,8 & 164,9 & 161,2 \\
\hline & $\% 1990$ & - & 100 & 106 & 109 & 112 & 102 & 102 & 98 & 102 & 102 & 101 & 99 \\
\hline Aandeel duurzaam a), c) & $\%$ & - & - & 0,1 & 0,5 & 1,9 & 2,5 & 2,9 & 4,2 & 4,9 & 5,4 & 6,6 & 7,3 \\
\hline Aandeel duurzaam Nederland f) & $\%$ & & & 1,6 & 2,5 & 3,9 & 4,7 & 4,8 & 5,5 & 5,8 & 6,0 & 6,6 & 7,4 \\
\hline
\end{tabular}




\section{Bijlage 3 Energiegebruik glastuinbouw (totale glastuinbouwareaal en niet gecorrigeerd voor temperatuur) a)}

\begin{tabular}{|c|c|c|c|c|c|c|c|c|c|c|c|c|c|}
\hline Energiesoort & Eenheid & 1980 & 1990 & 2000 & 2005 & 2010 & 2012 & 2013 & 2014 & 2015 & 2016 & 2017 & $2018 v$ \\
\hline Aardgas & miljoen $\mathrm{m}^{3}$ & 3.352 & 3.778 & 3.709 & 3.593 & 4.500 & 3.846 & 3.846 & 3.162 & 3.212 & 3.171 & 3.213 & 3.199 \\
\hline Overig fossiel b) & miljoen $\mathrm{m}^{3}$ a.e. & - & 30 & 1 & 3 & 2 & 1 & 1 & 1 & 1 & 1 & 1 & 1 \\
\hline Inkoop warmte c) & PJ & 0 & 1,9 & 14,9 & 9,1 & 5,3 & 4,5 & 4.2 & 3,4 & 3,5 & 3,7 & 3,7 & 3,4 \\
\hline \multicolumn{14}{|l|}{ Elektriciteit } \\
\hline - inkoop totaal & miljoen kWh & - & - & 1.479 & 2.626 & 2.169 & 2.213 & 2.488 & 2.206 & 2.507 & 2.699 & 2.849 & 2.845 \\
\hline - wv groen & miljoen $\mathrm{kWh}$ & - & - & 0 & 55 & 175 & 160 & 140 & 150 & 210 & 260 & 530 & 400 \\
\hline - verkoop & miljoen kWh & - & - & 266 & 1298 & 8.397 & 6.889 & 6.873 & 5.244 & 5.245 & 4.953 & 5.372 & 5.625 \\
\hline - wv groen & miljoen kWh & - & - & - & - & 21 & 19 & 22 & 27 & 28 & 28 & 27 & 27 \\
\hline - netto-inkoop & miljoen kWh & - & - & 1.213 & 1.328 & -6.228 & -4.676 & -4.385 & -3.038 & -2.738 & -2.254 & -2.523 & -2.780 \\
\hline Duurzame energie & PJ & - & - & 0,1 & 0,6 & 2,4 & 2,8 & 3,3 & 4,0 & 4,9 & 5,4 & 6,7 & 7,3 \\
\hline Totaal energie & PJ & - & - & 136,7 & 128,1 & 127,1 & 111,6 & 112,9 & 96,0 & 99,4 & 100,4 & 101,1 & 100,5 \\
\hline Totaal fossiel & miljoen $\mathrm{m}^{3}$ a.e. & - & 3.808 & 3.710 & 3.596 & 4.502 & 3.847 & 3.847 & 3.163 & 3.213 & 3.172 & 3.214 & 3.200 \\
\hline
\end{tabular}

$v$ = voorlopige cijfers; - = cijfers niet beschikbaar

a) de verkoop van warmte komt voor sinds 2007 maar is in deze tabel niet opgenomen, omdat het een zeer beperkte hoeveelheid betreft; b) zware en lichte olie en propaan; c) exclusief inkoop duurzame warmte. 


\section{Bijlage 4 Gebruik en reductie $\mathrm{CO}_{2}$-emissie per duurzame energiebron en inkoop $\mathrm{CO}_{2}$}

\begin{tabular}{|c|c|c|c|c|c|c|c|c|c|c|c|c|c|}
\hline \multirow[t]{3}{*}{ Duurzame energiebron } & \multirow{2}{*}{\multicolumn{5}{|c|}{ Areaal c), aantal bedrijven c), vermogen c) en/of hoeveelheid }} & \multicolumn{8}{|c|}{ Reductie $\mathrm{CO}_{2}$-emissie (Mton) } \\
\hline & & & & & & \multicolumn{4}{|c|}{ sector/IPCC } & \multicolumn{4}{|c|}{ nationaal/primair brandstof } \\
\hline & 2010 & 2015 & 2016 & 2017 & $2018 v$ & 2010 & 2016 & 2017 & $2018 v$ & 2010 & 2016 & 2017 & $2018 v$ \\
\hline Aardwarmte & $\begin{array}{l}1 \text { bedrijf } \\
21 \text { ha }\end{array}$ & $\begin{array}{l}34 \text { bedrijven } \\
459 \text { ha }\end{array}$ & $\begin{array}{l}43 \text { bedrijven } \\
503 \text { ha }\end{array}$ & $\begin{array}{l}55 \text { bedrijven } \\
621 \text { ha }\end{array}$ & $\begin{array}{l}81 \text { bedrijven } \\
741 \text { ha }\end{array}$ & 0,015 & 0,149 & 0,161 & 0,195 & 0,014 & 0,134 & 0,145 & 0,174 \\
\hline \multicolumn{14}{|l|}{ Zonne-energie } \\
\hline - warmte a) & $\begin{array}{l}55 \text { bedrijven } \\
216 \text { ha }\end{array}$ & $\begin{array}{l}64 \text { bedrijven } \\
211 \text { ha }\end{array}$ & $\begin{array}{l}61 \text { bedrijven } \\
205 \text { ha }\end{array}$ & $\begin{array}{l}61 \text { bedrijven } \\
210 \text { ha }\end{array}$ & $\begin{array}{l}62 \text { bedrijven } \\
214 \text { ha }\end{array}$ & 0,042 & 0,042 & 0,044 & 0,040 & 0,014 & 0,016 & 0,017 & 0,014 \\
\hline - elektriciteit & $\begin{array}{l}1 \text { bedrijf } \\
8 \text { ha }\end{array}$ & $\begin{array}{l}3 \text { bedrijven } \\
65 \text { ha }\end{array}$ & $\begin{array}{l}6 \text { bedrijven } \\
149 \text { ha }\end{array}$ & $\begin{array}{l}51 \text { bedrijven } \\
223 \text { ha }\end{array}$ & $\begin{array}{l}62 \text { bedrijven } \\
257 \text { ha }\end{array}$ & 0 & 0 & 0 & 0 & $<0,001$ & 0,002 & 0,004 & 0,007 \\
\hline \multicolumn{14}{|l|}{ Biobrandstoffen } \\
\hline \multirow[t]{2}{*}{$\begin{array}{l}\text { - warmte } \\
\text { - warmte plus elektriciteit b) }\end{array}$} & $\begin{array}{l}22 \text { bedrijven } \\
80 \text { ha } \\
4 \text { bedrijven }\end{array}$ & $\begin{array}{l}28 \text { bedrijven } \\
117 \text { ha } \\
4 \text { bedrijven }\end{array}$ & $\begin{array}{l}32 \text { bedrijven } \\
130 \text { ha } \\
4 \text { bedrijven }\end{array}$ & $\begin{array}{l}32 \text { bedrijven } \\
130 \text { ha } \\
5 \text { bedrijven }\end{array}$ & $\begin{array}{l}35 \text { bedrijven } \\
150 \text { ha } \\
6 \text { bedrijven }\end{array}$ & 0,009 & 0,026 & 0,027 & 0,029 & 0,009 & 0,025 & 0,026 & 0,028 \\
\hline & $\begin{array}{l}45 \mathrm{ha} \\
5 \mathrm{MWe}\end{array}$ & $\begin{array}{l}19 \mathrm{ha} \\
4 \mathrm{MWe}_{\mathrm{e}}\end{array}$ & $\begin{array}{l}19 \mathrm{ha} \\
4 \mathrm{MWe}_{\mathrm{e}}\end{array}$ & $\begin{array}{l}44 \mathrm{ha} \\
5 \mathrm{MWe}_{\mathrm{e}}\end{array}$ & $\begin{array}{l}45 \mathrm{ha} \\
5 \mathrm{MW}_{\mathrm{e}}\end{array}$ & 0,009 & 0,011 & 0,011 & 0,011 & 0,019 & 0,025 & 0,026 & 0,024 \\
\hline Inkoop duurzame elektriciteit & $17510^{6} \mathrm{kWh}$ & $20010^{6} \mathrm{kWh}$ & $26010^{6} \mathrm{kWh}$ & $53010^{6} \mathrm{kWh}$ & $40010^{6} \mathrm{kWh}$ & 0 & 0 & 0 & 0 & 0,082 & 0,118 & 0,235 & 0,177 \\
\hline \multicolumn{14}{|l|}{ Inkoop duurzame warmte } \\
\hline - centraal & - & - & - & - & - & 0,012 & $<0,001$ & $<0,001$ & 0,006 & 0,012 & $<0,001$ & $<0,001$ & 0,006 \\
\hline - decentraal & $\begin{array}{l}6 \text { bedrijven } \\
30 \text { ha }\end{array}$ & $\begin{array}{l}7 \text { bedrijven } \\
33 \text { ha }\end{array}$ & $\begin{array}{l}7 \text { bedrijven } \\
33 \text { ha }\end{array}$ & $\begin{array}{l}7 \text { bedrijven } \\
33 \text { ha }\end{array}$ & $\begin{array}{l}9 \text { bedrijven } \\
68 \text { ha }\end{array}$ & 0,008 & 0,014 & 0,014 & 0,035 & 0,007 & 0,013 & 0,013 & 0,034 \\
\hline Inkoop duurzaam gas & $110^{6} \mathrm{~m}^{3}$ & $110^{6} \mathrm{~m}^{3}$ & $110^{6} \mathrm{~m}^{3}$ & $110^{6} \mathrm{~m}^{3}$ & $110^{6} \mathrm{~m}^{3}$ & 0,002 & 0,002 & 0,002 & 0,002 & 0,002 & 0,002 & 0,002 & 0,002 \\
\hline Totaal duurzame energie & d) & d) & d) & d) & d) & 0,096 & 0,244 & 0,259 & 0,318 & 0,159 & 0,355 & 0,469 & 0,466 \\
\hline Inkoop $\mathrm{CO}_{2}$ & 0,51-0,54 Mton & 0,51-0,55 Mton & 0,54-0,57 Mton & $0,56-0,60$ Mton & $0,62-0,66$ Mton & $\#$ & $\#$ & $\#$ & $\#$ & $\#$ & $\#$ & $\#$ & $\#$ \\
\hline
\end{tabular}




\section{Bijlage 5 Gebruik en reductie $\mathrm{CO}_{2}$-emissie wkk en inkoop van warmte}

\begin{tabular}{|c|c|c|c|c|c|c|c|c|c|c|c|c|c|}
\hline \multirow[t]{3}{*}{ Wkk-vorm } & \multirow{2}{*}{\multicolumn{5}{|c|}{$\begin{array}{l}\text { Areaal (ha) b) } \\
\text { vermogen b) }\end{array}$}} & \multicolumn{8}{|c|}{ Reductie $\mathrm{CO}_{2}$-emissie (Mton) } \\
\hline & & & & & & \multicolumn{4}{|c|}{ sector/IPCC } & \multicolumn{4}{|c|}{ nationaal/primair brandstof } \\
\hline & 2010 & 2015 & 2016 & 2017 & $2018 v$ & 2010 & 2016 & 2017 & $2018 v$ & 2010 & 2016 & 2017 & $2018 \mathrm{v}$ \\
\hline Wkk-tuinder & $2.308 \mathrm{MW}_{\mathrm{e}}$ & $2.396 \mathrm{MW}_{\mathrm{e}}$ & $2.481 \mathrm{MW}_{\mathrm{e}}$ & $2.404 \mathrm{MW}_{\mathrm{e}}$ & $2.424 \mathrm{MW}_{\mathrm{e}}$ & $-2,60$ & $-2,23$ & $-2,48$ & $-2,56$ & 1,88 & 1,49 & 1,56 & 1,61 \\
\hline Restwarmte a) & $430-450$ ha & $470-480$ ha & $480-490$ ha & $490-510$ ha & $470-490$ ha & 0,199 & 0,196 & 0,199 & 0,185 & 0,142 & 0,145 & 0,153 & 0,143 \\
\hline $\begin{array}{l}\text { Wkk-warmte } \\
\text { energiebedrijven }\end{array}$ & $102 \mathrm{MWe}$ & $22 \mathrm{MWe}_{\mathrm{e}}$ & $16 \mathrm{MWe}_{\mathrm{e}}$ & $10 \mathrm{MWe}$ & $10 \mathrm{MWe}_{\mathrm{e}}$ & 0,091 & 0,007 & 0,002 & 0,001 & 0,061 & 0,004 & 0,001 & $<0,001$ \\
\hline Totaal & b) & b) & b) & b) & b) & $-2,31$ & $-2,03$ & $-2,28$ & $-2,37$ & 2,08 & 1,64 & 1,71 & 1,75 \\
\hline
\end{tabular}

$v=$ voorlopig cijfer

a) exclusief aandeel duurzaam; b) door het gebruik van meerdere wkk-vormen op hetzelfde areaal is sommatie niet mogelijk. 
Wageningen Economic Research Postbus 29703

2502 LS Den Haag

T 0703358330

Ecommunications.ssg@wur.nl

www.wur.nl/economic-research

Wageningen Economic Research RAPPORT

2019-111
De missie van Wageningen University \& Research is 'To explore the potential of nature to improve the quality of life'. Binnen Wageningen University \& Research bundelen Wageningen University en gespecialiseerde onderzoeksinstituten van Stichting Wageningen Research hun krachten om bij te dragen aan de oplossing van belangrijke vragen in het domein van gezonde voeding en leefomgeving. Met ongeveer 30 vestigingen, 5.000 medewerkers en 10.000 studenten behoort Wageningen University \& Research wereldwijd tot de aansprekende kennisinstellingen binnen haar domein. De integrale benadering van de vraagstukken en de samenwerking tussen verschillende disciplines vormen het hart van de unieke Wageningen aanpak. 



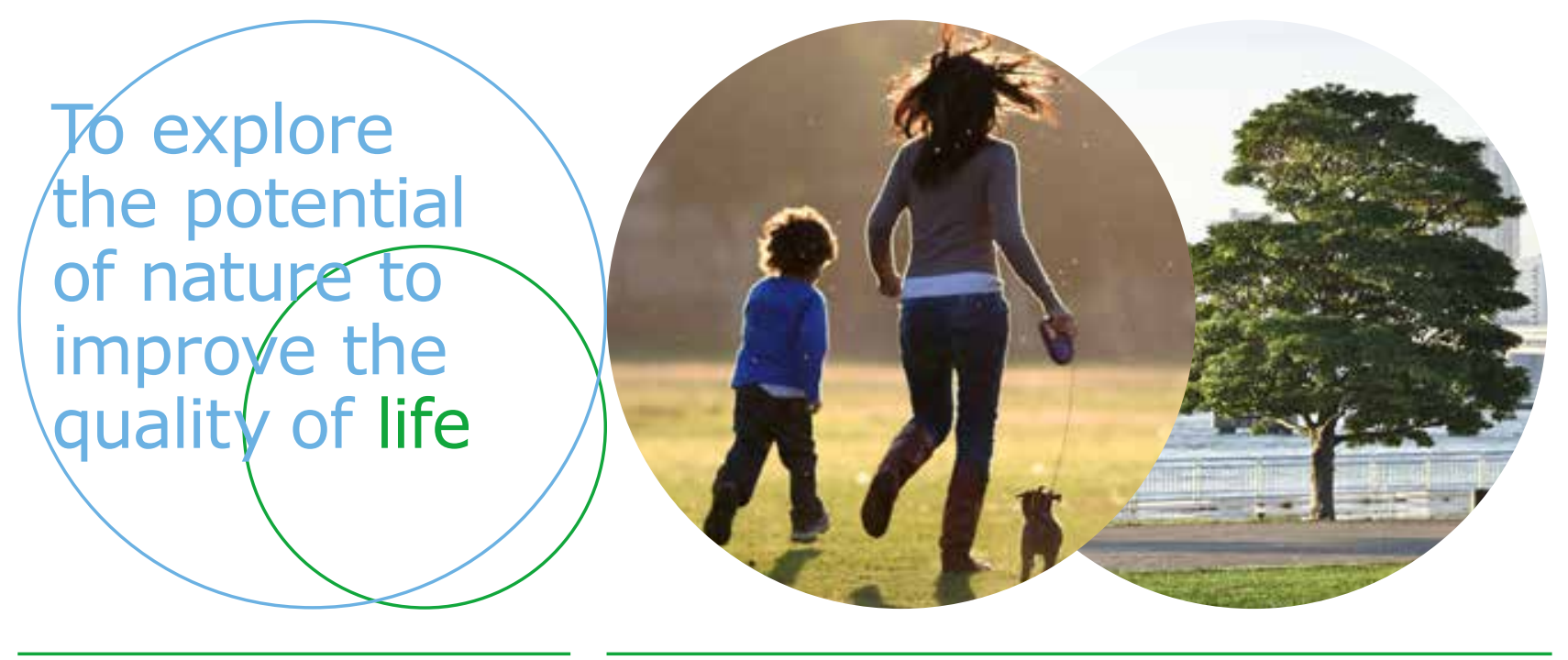

Wageningen Economic Research Postbus 29703

2502 LS Den Haag

E communications.ssg@wur.nl

$\mathrm{T}+31(0) 703358330$

www.wur.nl/economic-research

Report 2019-111

ISBN 978-94-6395-204-0
De missie van Wageningen University \& Research is 'To explore the potential of nature to improve the quality of life'. Binnen Wageningen University \& Research bundelen Wageningen University en gespecialiseerde onderzoeksinstituten van Stichting Wageningen Research hun krachten om bij te dragen aan de oplossing van belangrijke vragen in het domein van gezonde voeding en leefomgeving. Met ongeveer 30 vestigingen, 5.000 medewerkers en 10.000 studenten behoort Wageningen University \& Research wereldwijd tot de aansprekende kennisinstellingen binnen haar domein. De integrale benadering van de vraagstukken en de samenwerking tussen verschillende disciplines vormen het hart van de unieke Wageningen aanpak. 